\title{
GEOHYDROLOGY AND WATER RESOURCES OF ALLUVIAL BASINS IN SOUTH-CENTRAL ARIZONA AND PARTS OF ADJACENT STATES
}

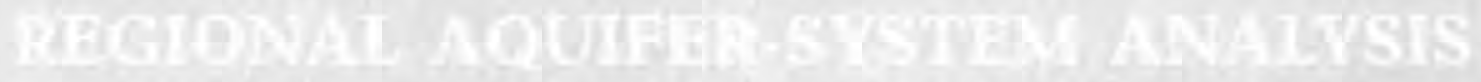

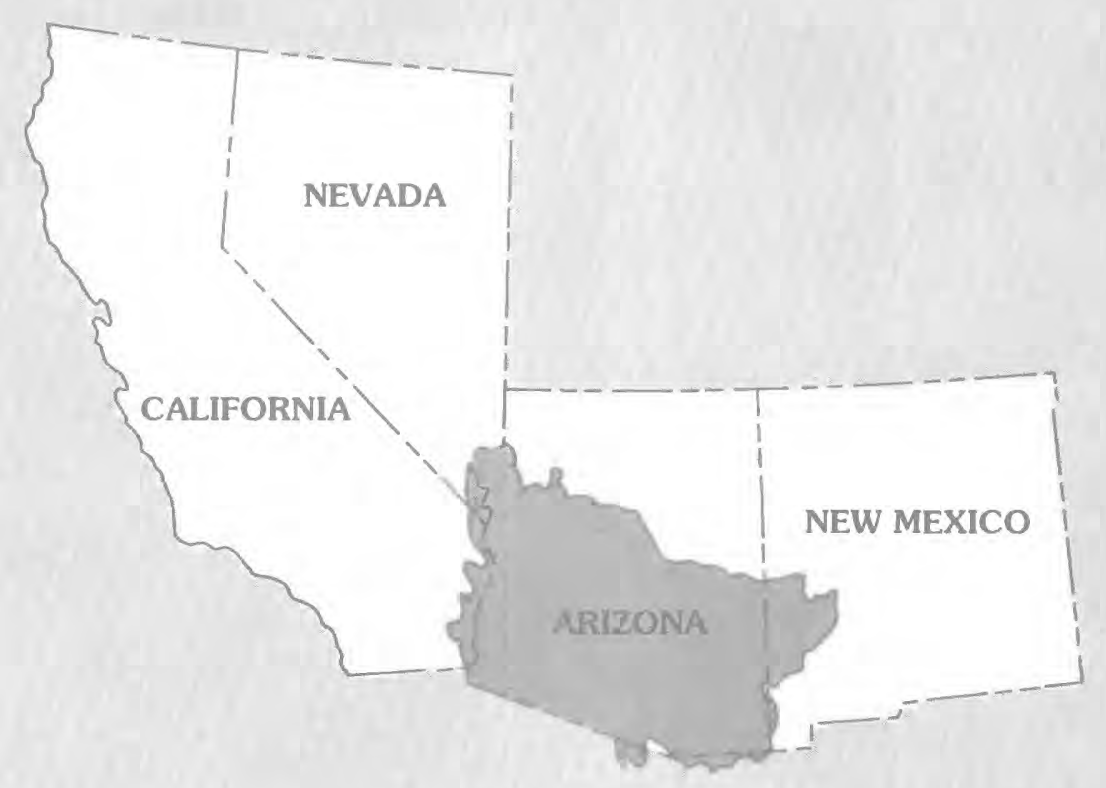





\section{Geohydrology and Water Resources of Alluvial Basins in South-Central Arizona and Parts of Adjacent States}

By T.W. ANDERSON, GEOFFREY W. FREETHEY, and PATRICK TUCCI

REGIONAL AQUIFER-SYSTEM ANALYSIS-

SOUTHWEST ALLUVIAL BASINS, ARIZONA AND ADJACENT STATES

U.S. GEOLOGICAL SURVEY PROFESIONAL PAPER 1406-B

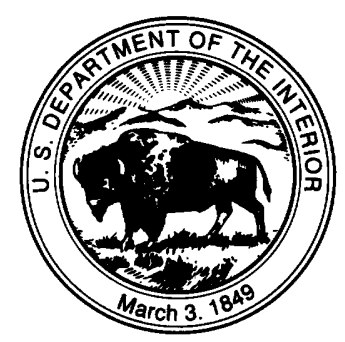




\section{U.S. DEPARTMENT OF THE INTERIOR}

MANUEL LUJAN, Jr., Secretary

\section{U.S. GEOLOGICAL SURVEY}

Dallas L. Peck, Director

Any use of trade, product, or firm names in this publication is for descriptive purposes only and does not imply endorsement by the U.S. Government

\section{Library of Congress Cataloging in Publication Data}

Anderson, T.W. (Thomas Warren), 1940-

Geohydrology and water resources of alluvial basins in south-central Arizona and parts of adjacent states / by T.W. Anderson, Geoffrey W. Freethey, and Patrick Tucci.

p. $\quad$ cm. - (Regional aquifer-system analysis) (U.S. Geological Survey professional paper ; 1406-B) Includes bibliographical references.

1. Aquifers-Arizona 2. Water quality-Arizona I. Freethey, Geoffrey W. II. Tucci, Patrick. III. Title. IV. Series. V. Series: U.S. Geological Survey professional paper ; 1406-B.

GB1199.A7A54 1991

553.7'9'09791—dc20

For sale by Book and Open-File Report Sales, U.S. Geological Survey,

Box 25425, Denver, CO 80225 


\section{FOREWORD}

THE REGIONAL AQUIFER-SYSTEM ANALYSIS PROGRAM

The Regional Aquifer-System Analysis (RASA) Program was started in 1978 following a congressional mandate to develop quantitative appraisals of the major ground-water systems of the United States. The RASA Program represents a systematic effort to study a number of the Nation's most important aquifer systems, which in aggregate underlie much of the country and which represent an important component of the Nation's total water supply. In general, the boundaries of these studies are identified by the hydrologic extent of each system and accordingly transcend the political subdivisions to which investigations have often arbitrarily been limited in the past. The broad objective for each study is to assemble geologic, hydrologic, and geochemical information, to analyze and develop an understanding of the system, and to develop predictive capabilities that will contribute to the effective management of the system. The use of computer simulation is an important element of the RASA studies, both to develop an understanding of the natural, undisturbed hydrologic system and the changes brought about in it by human activities, and to provide a means of predicting the regional effects of future pumping or other stresses.

The final interpretive results of the RASA Program are presented in a series of U.S. Geological Survey Professional Papers that describe the geology, hydrology, and geochemistry of each regional aquifer system. Each study within the RASA Program is assigned a single Professional Paper number, and where the volume of interpretive material warrants, separate topical chapters that consider the principal elements of the investigation may be published. The series of RASA interpretive reports begins with Professional Paper 1400 and thereafter will continue in numerical sequence as the interpretive products of subsequent studies become available.

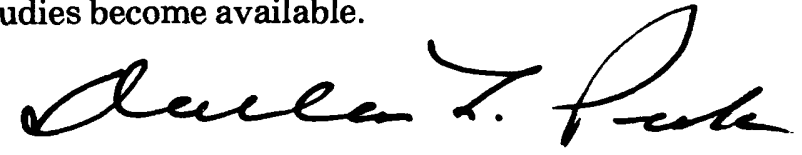

Dallas L. Peck

Director 



\section{CONTENTS}

Page

Abstract -

Introduction

Purpose and scope

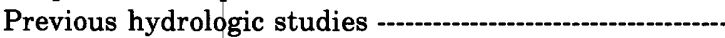

Study area -

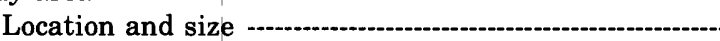

Climate

Physiographic and hydrologic subdivisions

Methods of investigation

Geophysics

Ground-water chemistry

Geohydrology

Rocks of the mountains

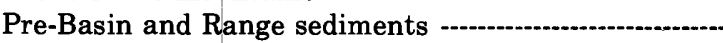

Basin-fill sediments

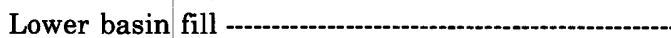

Upper basin fill

Stream alluvium

Occurrence and movement of ground water ..................

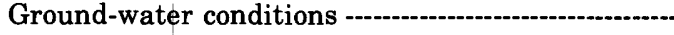

Structural influence

Influence of rock type on basin hydrology -.......-...-

Water-bearing characteristics of the basin sediments

Pre-Basin and Range sediments --.--.--

Basin-fill sediments

Stream alluvium

Water-resources development

History of development

Response of aquifer systems to ground-water development

Regional water budget

Summary of flow components

Inflow to aquifers -

Aquifer storage and movement of ground water -..

Outflow from aquifers

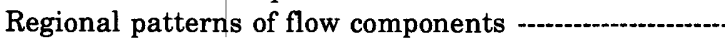

Ground-water underflow

Mountain-front recharge

Streamflow infiltration
Page

B1

1

3

3

4

4

4

7

7

7

11

13

13

14

15

17

17

19

19

20

20

20

21

21

22

24

25

25

26

26

27

28

30

30

32

32

33

34

Regional water budget-Continued

Regional patterns of flow components-Continued

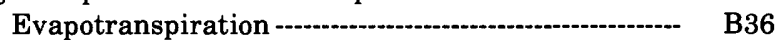

Effects of development on basin water budgets --- $\quad 36$

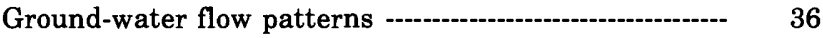

Areal pattern of hydraulic heads --.--.--.--.-- 36

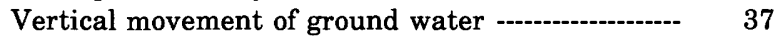

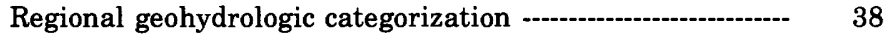

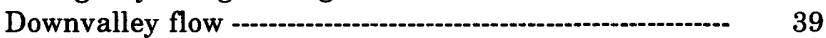

Lithology of basin sediments -

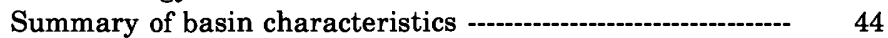

Southeast basins -

Lithology -.--.-- 44

Hydrology -...- 45

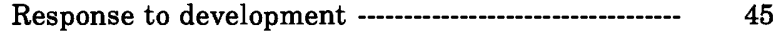

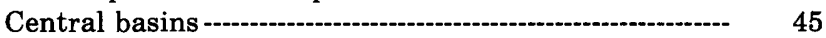

Lithology -

Hydrology -

Response to development -

West basins -

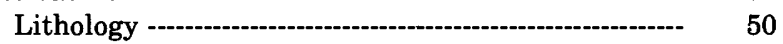

Hydrology -

Response to development -

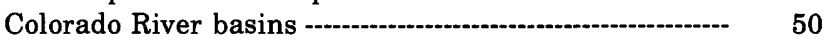

Lithology - - 50

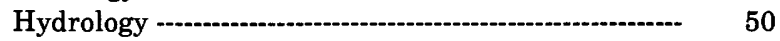

Response to development -

Highland basins -

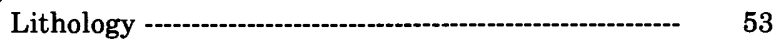

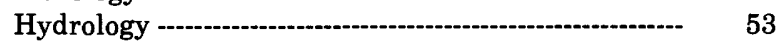

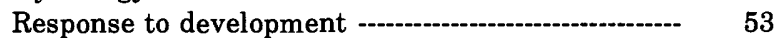

Water-resources development and effects on hydrologic

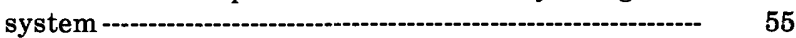

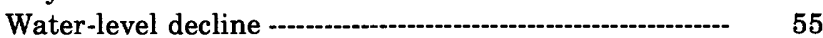

Streamflow depletion -.-.-.-- 57

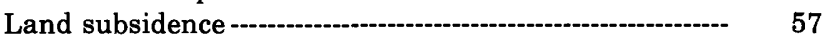

Changes in hydraulic characteristics with depth ------. 59

Management of water resources -

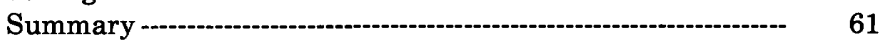

Selected references -

\section{ILLUSTRATIONS}

[Plates are in pocket]

Plates 1-3. Maps showing:

1. Generalized geology of the study area in south-central Arizona and parts of adjacent States.

2. Generalized long-term water-level declines through 1980 in alluvial-basin aquifers in south-central Arizona and parts of adjacent States.

3. Generalized predevelopment water-level conditions and ground-water flow directions in alluvial-basin aquifers in south-central Arizona and parts of adjacent States. 
FIgures 1-5. Maps showing: Page

1. Basin and Range physiographic province and the Southwest Alluvial Basins study area --..-...-..- B2

2. Climatic features of the study area

3. Areal subdivisions of the study area in Arizona -

4. General subdivisions of the study area based on climatic, physiographic, and hydrologic characteristics and geologic structure

5. Areas of application of various geophysical methods

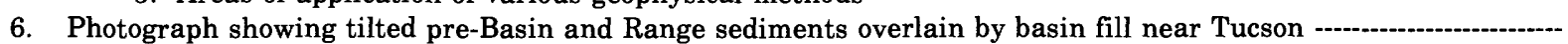

7. Sketch showing generalized section and description of principal hydrogeologic units of basins of the study area -

8. Map showing generalized areal extent of two groups of lower basin-fill sediments in the study area -.-.-.... 9-10. Graphs showing:

9. Relation of percentage of fine-grained material in drilling samples, hydraulic conductivity, and distance from mountain front for basin fill in east Salt River Valley and the Tucson basin -.-.-.-.-.-.-.-.-.-.-

10. Annual ground-water withdrawals, 1915-80

11. Sketch showing typical inflow and outflow components for predevelopment conditions in basins of the study area

12. Map showing ground-water underflow into and out of the study area. -

13. Diagrams showing relation of estimated mountain-front recharge to total volume of precipitation -..............-..-14-18. Maps showing:

14. Stream reaches in which infiltration was a significant part of the predevelopment water budget -.........

15. Extremes in shape of water-level contours in basins of the study area -

16. U-shaped water-level contours that are indicative of multiple inflow and outflow components in the Tucson basin

17. Categories of alluvial basins based on geohydrologic factors

18. Basin categories based on annual unit downvalley flow

19. Graph showing conceptual relation of annual unit downvalley flow and magnitude of development in a basin ----

20. Maps showing approximate areal extent of sedimentary deposits in the study area --

21-25. Sketches showing generalized geologic and hydrologic characteristics of the:

21. Southeast basins

22. Central basins

23. West basins

24. Colorado River basins - -

25. Highland basins

26. Hydrographs showing historical changes in water levels in selected wells

27. Photographs showing earth fissures and effects of land subsidence in alluvial basins near Eloy and Phoenix, Arizona -

28. Map showing Active Management Areas and Irrigation Nonexpansion Areas in Arizona -

\section{TABLES}

TABLE 1. Climatic characteristics of the study area

2. Estimates of water budget before development 


\section{CONVERSION FACTORS AND ABBREVIATIONS}

For readers who wish to convert measurements from the inch-pound system of units to the metric system of units, the conversion factors are listed below:

\begin{tabular}{rll}
\hline Multiply inch-pound units & By & To obtain metric units \\
\hline inch (in.) & 25.4 & millimeter $(\mathrm{mm})$ \\
foot $(\mathrm{ft})$ & 0.3048 & meter $(\mathrm{m})$ \\
square mile $\left(\mathrm{mi}^{2}\right)$ & 2.590 & square $\mathrm{kilometer}\left(\mathrm{km}^{2}\right)$ \\
gallon per minute $(\mathrm{gal} / \mathrm{min})$ & 0.06309 & liter per second $(\mathrm{L} / \mathrm{s})$ \\
foot per year $(\mathrm{ft} / \mathrm{yr})$ & 0.3048 & meter per year $\left(\mathrm{m} / \mathrm{yr}^{2}\right)$ \\
acre-foot (acre-ft) & 0.001233 & cubic hectometer $\left(\mathrm{hm}^{3}\right)$ \\
cubic hectometer per square \\
acre-foot per acre per year & 0.3048 & hectometer per year $\left[\left(\mathrm{hm}^{3} / \mathrm{hm}^{2}\right) / \mathrm{yr}\right]$ \\
[(acre-ft/acre)/yr] & & meter squared per day $\left(\mathrm{m}^{2} / \mathrm{d}\right)$ \\
foot squared per day $(\mathrm{ft} / \mathrm{d})$ & 0.0929 & liter per second per meter \\
gallon per minute per foot & 0.207 & {$[(\mathrm{~L} / \mathrm{s}) / \mathrm{m}]$} \\
[(gal/min)/ft] & &
\end{tabular}

\section{SEA LEVEL}

In this report, "sea level" refers to the National Geodetic Vertical Datum of 1929 (NGVD of 1929) - a geodetic datum derived from a general adjustment of the first-order level nets of both the United States and Canada, formerly called "Sea Level Datum of 1929." 



\title{
GEOHYDROLOGY AND WATER RESOURCES OF ALLUVIAL BASINS IN SOUTH- CENTRAL ARIZONA AND PARTS OF ADJACENT STATES
}

\author{
By T.W. Anderson, Geoffrey W. Freethey, and Patrick Tucci
}

\section{ABSTRACT}

The alluvial basins described in this report include about 82,000 square miles in south-central Arizona and parts of adjacent States. The area is composed of 72 basins that are virtually independent hydrologic systems.

The study area is part of the Basin and Range physiographic province and is characterized by broad valleys separated by sharply rising mountain ranges. The climate is arid to semiarid. Precipitation generally ranges from 3 to 30 inches per year; potential evaporation ranges from 60 to 86 inches per year.

A distinct sequence of sediments occurs in the basins and consists of (1) pre-Basin and Range sediments, (2) lower basin fill formed prior to the development of integrated drainage and characterized by extensive fine-grained deposits, evaporites, and volcanics, (3) upper basin fill formed as the regional drainage network became integrated and which is generally composed of coarser grained material than the lower basin fill, and (4) stream alluvium deposited during the establishment of the present drainage system and consisting mainly of sand and gravel. These sediments range from a few thousand feet to more than 10,000 feet in thickness, may be unconsolidated to highly consolidated, are hydraulically interconnected, and form the principal aquifers in the basins of the study area. In contrast, the rocks of the mountains that surround the basins yield little or no water.

Ground water occurs within pore spaces of the basin sediments. In general, all sediments in a basin are hydraulically connected and form a single aquifer. Ground water generally occurs under unconfined conditions, although in places, confined conditions may occur where extensive fine-grained material is present. Generally, sediments are finer in the basin centers and coarser near the mountain ranges. Depths to the water table range from at land surface near some streams to as much as 1,300 feet below land surface near some mountain fronts.

Before development, inflow was about 2.5 million acre-feet per year of water in the study area, which consisted of infiltration along major streams, mountain-front recharge, and underflow. Outflow consisted of evapotranspiration and underflow. The amount of inflow and outflow was small in relation to the estimated 900 million acre-feet of water stored in the basin-fill sediments to a depth of 1,200 feet below land surface.

Development of water resources in the study area has resulted in a decrease in surface flow in some basins and depletion of aquifer storage in many basins. By 1980, a total of 184 million acre-feet of ground water had been withdrawn. Slightly more than 50 percent of this volume was estimated to be removed from aquifer storage; the remainder was balanced by decrease in natural ground-water discharge, increase in recharge, or a com- bination of both. Ground-water levels have declined from less than 50 feet to more than 450 feet in major developed basins. Annual rates of decline have ranged from less than a foot to more than 10 feet per year. The magnitude of ground-water depletion varies from basin to basin, reflecting the influence of the geohydrologic environment as well as the magnitude and duration of withdrawals.

The basins are grouped into five broad categories on the basis of the lithology and the type of hydrologic flow system. As the basins in each category tend to be in the same geographic area, categories were named (1) southeast, (2) central, (3) west, (4) Colorado River, and (5) highland basins. The lithology of the basin sediments and the existence of large rivers in basins, such as the Colorado River, are factors that control the movement and storage of ground water and control the effects of development on the basin aquifers. The quantity of downvalley flow represents the annually renewable water available without depleting aquifer storage.

Compaction of compressible fine-grained material in the basin fill associated with large declines of water levels creates land subsidence and earth fissures. Earth fissures occur mainly along the perimeter of the basins. At early stages in their development, the fissures are narrow; however, the fissures are widened by erosion or further earth movement, which creates serious problems for surface structures.

\section{INTRODUCTION}

The Southwest Alluvial Basins (Swab), Regional Aquifer-System Analysis (RASA) Project is one of a series of studies designed to systematically evaluate the Nation's major ground-water systems (Bennett, 1979). The study began in October 1978 and is one of 28 systems planned in the RASA program. In most of the RASA studies, the concept of a regional aquifer is that of a continuous, hydraulically connected groundwater system that is areally extensive and may include parts of several States. In these systems, data can be extrapolated and interpolated over large distances owing to similarities in geology and hydrology. Physical and hydraulic characteristics generally have a gradually varying spatial distribution.

The Swab/RASA study area in south-central Arizona and parts of adjacent States (fig. 1), which 

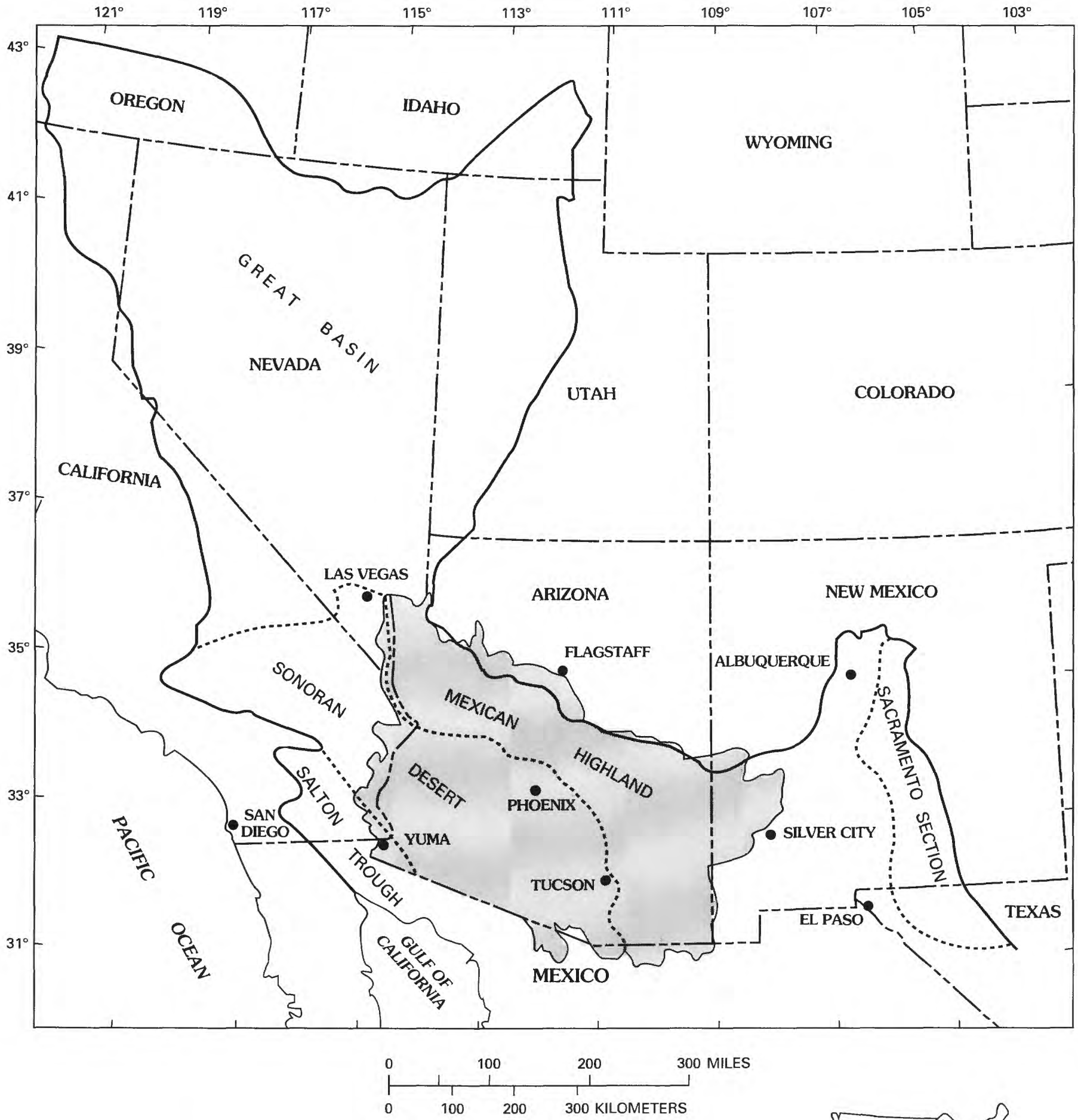

\section{EXPLANATION}

STUDY AREA

BOUNDARY OF BASIN AND RANGE PHYSIOGRAPHIC PROVINCE

BOUNDARY OF SECTIONS WITHIN BASIN AND RANGE PHYSIOGRAPHIC PROVINCE

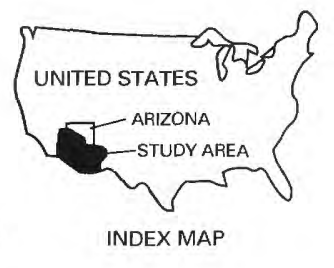

Figure 1.-Basin and Range physiographic province (from Fenneman, 1931) and the Southwest Alluvial Basins study area. 
consists of 72 individual basins that are virtually independent hydrologic systems, is a marked contrast to this general concept of a continuous ground-water system. The basins are structural depressions that were subsequently filled with alluvial sediments. These basins are enclosed or partly enclosed by mountains and either internally or externally drained. Tectonic activities associated with the Basin and Range disturbance (Fenneman, 1931) formed the basins that vary in width, length, and depth. Mountains surrounding the basins are the main source of detrital material that fills the basins. Although basins in the study area do not fit the classic concept of a regional aquifer, the combined basins are considered a regional hydrologic system because (1) they are areally extensive, although not continuous, (2) some basins are linked hydrologically, such as surface-water flow or ground-water flow from upstream basins to downstream basins, (3) groundwater development, response, and water-use characteristics of basin aquifers are similar, and (4) ground-water resources represent a common element in the economy of the entire region.

Water is one of the essential elements for economic development. Early settlers were attracted to the few areas of perennial streamflow. Variability of the surface-water supply in the study area was an ever-present problem, and with continued development, a need to improve the dependability of the supply of water became apparent. Surface water eventually was controlled by reservoirs, and augmentation by ground-water pumping followed. As development further expanded, ground-water resources in these basins were increasingly exploited. Longterm results were water-level declines and a depletion of ground water in storage. Exploitation of water resources continues, and depletion of water resources is a major concern. Ancillary problems of land subsidence and associated earth fissures, increased pumping costs, diminished aquifer productivity, and variability of water quality have become significant concerns. As the effects of land uses on the overall quantity and quality of water becomes more apparent, the need to improve understanding of the hydrologic systems and management of water resources in basins within the study area is essential.

\section{PURPOSE AND SCOPE}

The purpose of the study was to understand the flow system of the basin aquifers in south-central Arizona and parts of adjacent States. The specific ob- jectives of the project were to define the (1) extent of the basin aquifers, (2) boundary conditions within the basins, (3) flow conditions within the basins before and after development, (4) relation between streamflow and ground-water flow, and (5) water chemistry. Results of this study are intended to aid water managers and others by providing the description of the hydrogeologic framework and associated flow system of the basin aquifers that can be used to assess the effect of development on basin aquifers.

This report presents the hydrogeologic framework and associated hydrology. The study area was divided into 72 basins. The basin boundaries represent surface-water divides, zones of minimal interbasin connection, or, in some instances, arbitrary boundaries through areas of minimum ground-water development. A basin functions as the smallest hydrologic unit for analysis. The study is based on the assumption that some commonality exists among basins so that the basins can be grouped and categorized in a way that the study results can be transferred to basins having similar geologic and hydrologic characteristics. This report presents the concept of grouping the basins on the basis of similarities in hydrology and geology and documents the hydrogeology of the basin aquifers in each group.

\section{PREVIOUS HYDROLOGIC STUDIES}

Early study of the geohydrology of the area involved only individual basins. Such studies as those by Davis (1897) and Lee (1905) of the Phoenix area, Lee (1904) of Gila Valley, and Meinzer and Kelton (1913) of Sulphur Springs Valley represent the first evaluations of the occurrence and movement of ground water as well as the geologic setting and quality of ground water. These early studies generally indicated that vast quantities of ground water were available at shallow depth in many areas.

Since that time, a large amount of waterresources development has occurred, more data have become available, and more water-resources studies of individual basins have been completed. The results of many previous studies provided the foundation for this study. These studies continued to address the geohydrology of individual basins while documenting the effects of development on the availability of water resources and water quality. The principal references for these previous studies are listed in the "Selected References" section of this report.

The earliest report that incorporated information on a number of the basins of the Basin and Range 
province of southern Arizona is by Halpenny and others (1952). This report brought together brief discussions of the hydrology of individual basins for the first time into a single volume. Only basins in which significant ground-water development had occurred were discussed. Harshbarger and others (1966) were the first to examine the general geohydrologic environment, occurrence, and development of groundwater resources and the effects of overdevelopment of ground water in the alluvial basins of southern Arizona. The Arizona Water Commission (1975), in conjunction with the development of a State of Arizona water plan, compiled most of the pertinent information to document the magnitude of available water resources and the extent of historic uses. Brown (1976) prepared a regional appraisal of total ground water in storage, and Cooley (1977) described the geologic framework of the basins. All these studies included discussions of other parts of the State of Arizona as well. Davidson (1979) presented a summary of ground-water availability and the potential for greater development for the entire surface-water drainage of the lower Colorado River below Lees Ferry, Arizona, which includes all of the current study area.

As part of the current study, Freethey and others (1986) presented a general picture of the physical size and shape of all the basins as well as the general geologic setting of the basins. The purpose of that report is to document the physical extent of the individual alluvial basins. In a companion report, Freethey and Anderson (1986) presented a general synthesis of the hydrologic system in each basin for predevelopment conditions. The information presented included water budgets for each basin, an estimate of the volume of ground water in storage to a depth of $1,200 \mathrm{ft}$ below land surface, and estimated predevelopment water levels. The report by Freethey and Anderson (1986) presents the general steadystate conditions of the basin aquifers throughout the study area prior to development.

\section{STUDY AREA}

\section{LOCATION AND SIZE}

The study area encompasses about $82,000 \mathrm{mi}^{2}$ in southern and central Arizona, western New Mexico, and small parts of southeastern California and Nevada (fig. 1). The study area includes the surfacewater drainage of the Colorado River between Hoover Dam and the international boundary near Yuma. The San Bernardino and Douglas basins in southeastern Arizona and parts of several basins in southwestern Arizona are also included although these basins drain to Mexico. They are included in this study because of similarities in physical, climatic, and land-use characteristics to basins within the Colorado River drainage. The contiguous area to the east in New Mexico that extends into Texas is included in a concurrent RASA study of the Rio Grande trough and adjacent basins. Similarly, the basins to the west and northwest in the Basin and Range province in California, Utah, and Nevada are also included in RASA studies.

\section{CLIMATE}

The climate of the area is arid to semiarid; however, a wide range in conditions exists that can be linked directly to variations in altitude and indirectly to geologic structure through the distribution of mountains, valleys, and the adjacent Colorado Plateau. The climatic factor that best illustrates the arid to semiarid nature of the area and has the greatest influence on hydrology is the average annual precipitation. Average annual precipitation ranges from less than $3 \mathrm{in}$. in the Yuma area to about $30 \mathrm{in}$. in the high-elevation headwaters of the Salt and Gila Rivers (fig. 2A). Two distinct seasons of precipitation that have different characteristics are related to the source and direction of movement of atmospheric moisture. In the winter, moisture moves into the area from the Pacific Ocean and crosses from the west or southwest to the east or northeast. Winter precipitation covers large areas and is generally of low intensity and long duration. In the summer, moist tropical air moves from Mexico and crosses the eastern and central parts of the area from the south or southeast to the north or northwest. Summer precipitation occurs as high-intensity, short-duration thunderstorms that cover small areas (fig. 2B).

Lake evaporation and length of the frost-free period or growing season illustrate the wide range in climatic conditions and areal trends. Both characteristics are a function of temperature, which in turn is related to altitude. Average annual lake evaporation ranges from less than 60 in. in the high-altitude zones of the Salt, Verde, and Gila River drainages to about $86 \mathrm{in}$. along the downstream reach of the Colorado River, which is the most arid part of the study area (fig. $2 C$ ). The average annual length of the frost-free period ranges from 330 days in the Yuma area to about 90 days in the high-altitude zones (fig. $2 D$ ). 

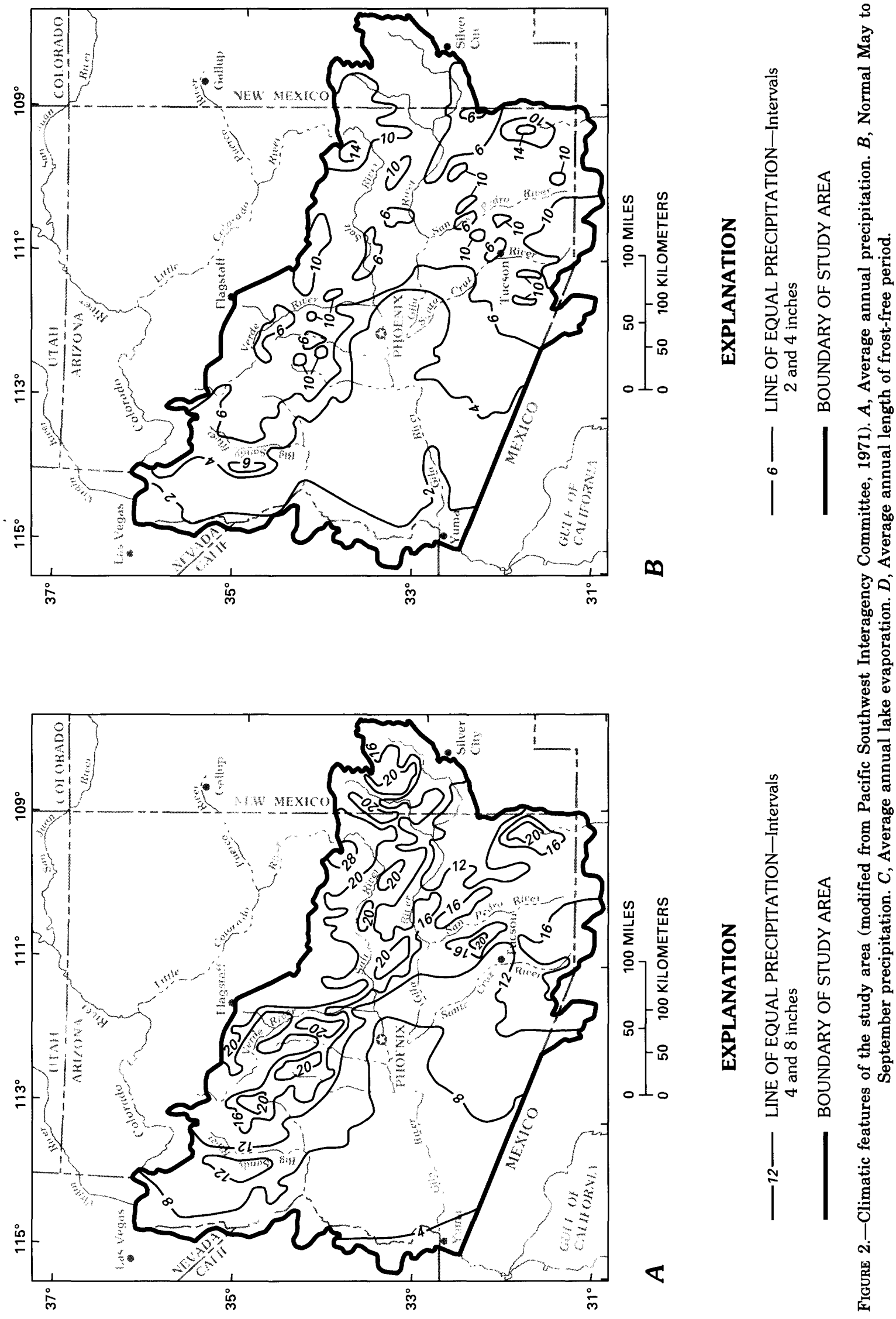

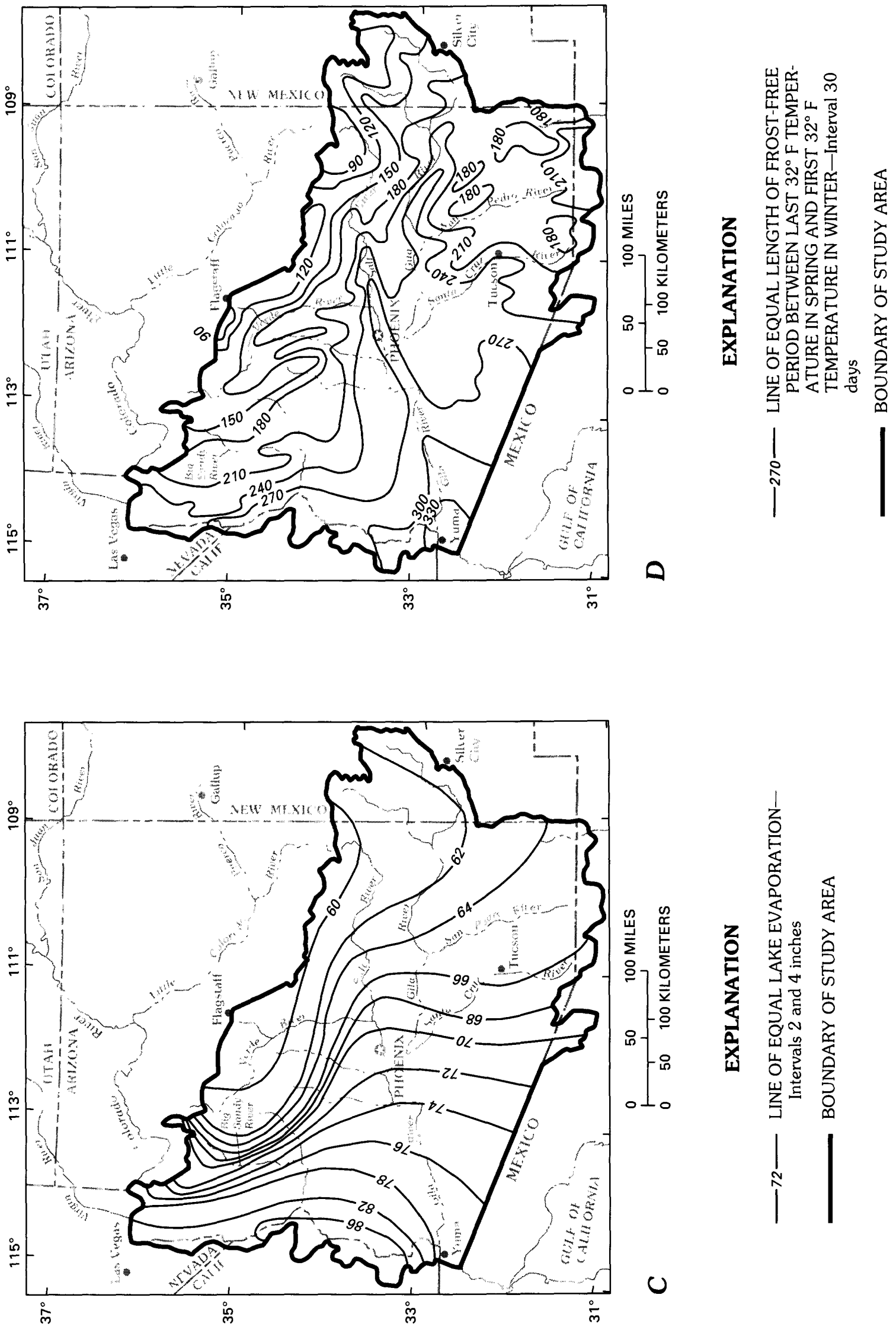

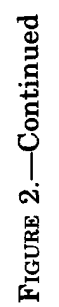

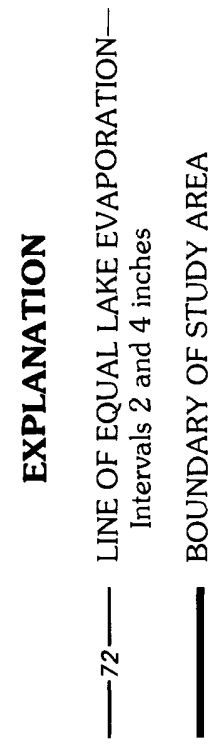




\section{PHYSIOGRAPHIC AND HYDROLOGIC SUBDIVISIONS}

The study area lies within the Basin and Range physiographic province as defined by Fenneman (1931) (fig. 1). This part of the province was divided into the Sonoran Desert and Mexican Highland sections. The Yuma basin in the southwest corner of the study area is within the Salton Trough section but because of its small areal extent is included with the basins of the Sonoran Desert section.

The Basin and Range physiographic province is typified by broad gently sloping valleys separated by sharply rising mountain ranges. Physiographic differences exist between the Mexican Highland and Sonoran Desert sections. These differences appear to be related principally to the differences in altitude between the two sections. The valleys of the Sonoran Desert section range in altitude from less than $500 \mathrm{ft}$ to more than $2,500 \mathrm{ft}$ above sea level; the surrounding mountains rise to altitudes of 1,000 to $2,000 \mathrm{ft}$ above the valley floors. In the Mexican Highland section, the valleys range in altitude from 2,500 to $4,000 \mathrm{ft}$ above sea level, and the mountains rise from about 2,000 to nearly $5,000 \mathrm{ft}$ above the valley floors. The valley floors are more areally extensive in the Sonoran Desert section; the mountains occupy less than 30 percent of the area. In the Mexican Highland, the valleys and mountains cover approximately equal areas.

Other investigators have modified Fenneman's original boundaries. Wilson (1962) divided the part of the study area in Arizona into two physiographic subareas, which are similar to the sections of Fenneman except in the northwest (fig. $3 A$ ). The mountain region contains the highest and widest mountain ranges. The desert region features low altitudes and more areally extensive valleys. Wilson (1962, p. 90) concluded that because of the influence of increasingly arid climate and its effects on the erosive processes, the mountain "topography becomes progressively more sharp and rugged southwest and westward."

The study area has also been divided on the basis of geologic structure. Wilson and Moore (1959) recognized that the boundary of the Basin and Range province was not distinct everywhere and proposed the addition of a transition zone (fig. $3 B$ ). This zone, although possessing some of the rock types of the Colorado Plateau, has undergone the more complex and intense deformation that is typical of the Basin and Range lowlands.

Another criteria for subdividing the area was the occurrence of ground water and surface water (U.S. Geological Survey, 1969). The three water provinces so defined (fig. $3 C$ ) also reflect the physiographic conditions. The Central highlands water province includes most of the perennial streams and was designated to represent a transition zone between the Plateau uplands and Basin and Range lowlands water province. A similar division was defined by Roeske (1978) and further used by Stiehr (1981) for analysis of surfacewater runoff characteristics (fig. $3 D$ ) and resembles Fenneman's sections of the Basin and Range province in Arizona. The implication is that the physiographic and surface-runoff characteristics are related, both being influenced by precipitation and altitude.

On the basis of characteristics of physiography, geologic structure, hydrology, surface runoff, and climate, the study area is divided into four subdivisions as shown in figure 4 . The climatic characteristics of each subdivision are summarized in table 1 . The significance of the differences in climatic characteristics is related to precipitation, which is the ultimate source of all water in the study area. Areal differences, therefore, may relate to variations in the quantity of water available for recharge and for development. The purpose of this division was to develop a basin categorization in which surficial similarities and differences between basins could be evaluated. A fundamental assumption was that differences in hydrology from basin to basin could be related to the characteristics given above.

\section{METHODS OF INVESTIGATION}

The hydrogeologic characteristics of the basin aquifers that need to be defined are (1) physical boundaries, (2) spatial distribution of hydrologic properties of the aquifer materials, and (3) spatial and temporal distribution of hydraulic heads in the basins. Data in files of the Geological Survey and various local, State, and other federal agencies were compiled, screened, interpreted, and synthesized. Field application of geophysical methods and collection of water samples for water-quality analysis were made to supplement the deficiencies of the compiled data base.

\section{GEOPHYSICS}

Subsurface geohydrologic information is limited in most basins. Test drilling and aquifer testing are expensive. Surface- and borehole-geophysical methods, therefore, were used as an inexpensive means of obtaining data over large areas.

Three geohydrologic features selected for analysis by geophysical methods were basin size and 

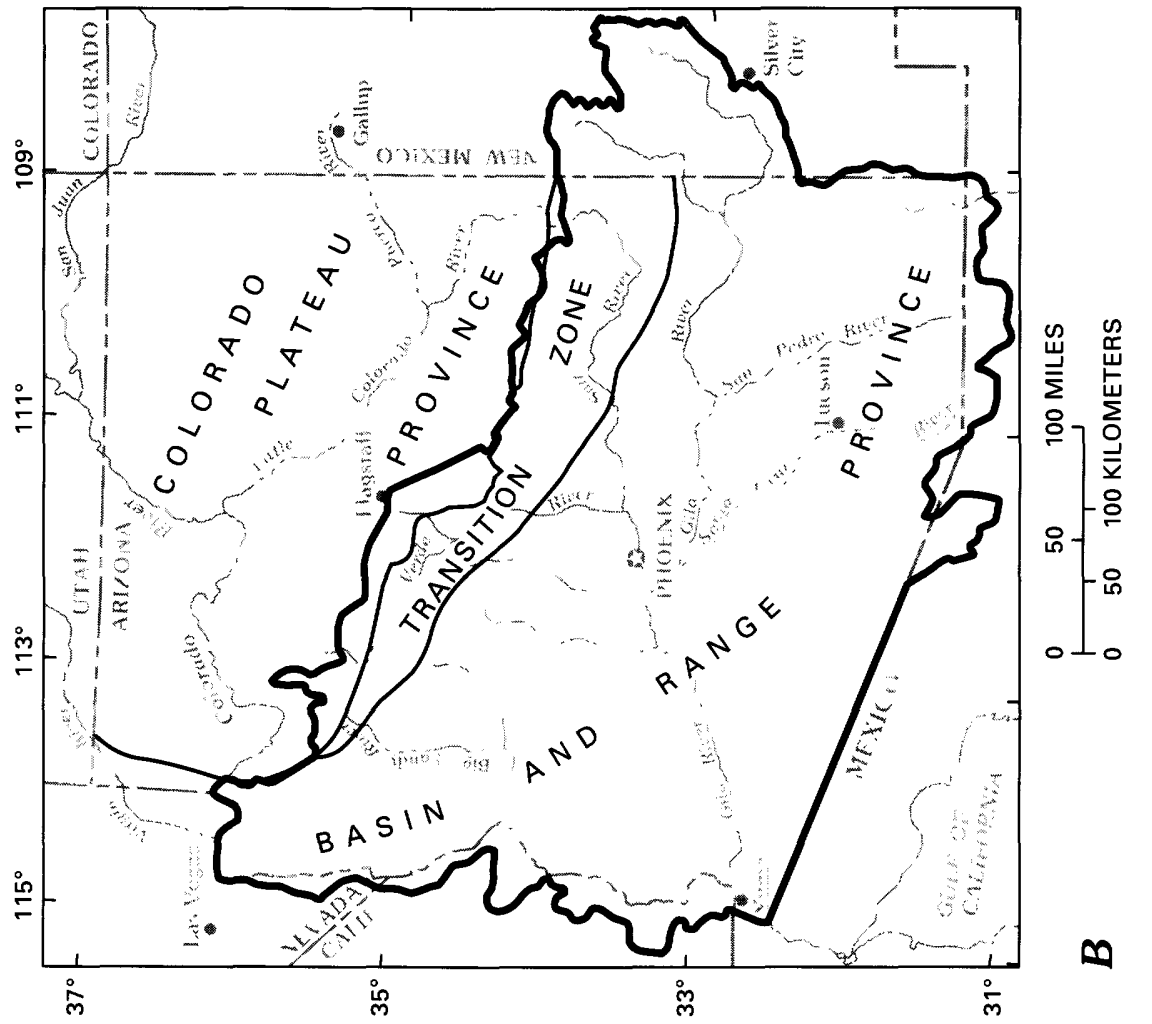

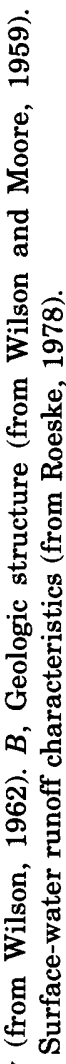

这
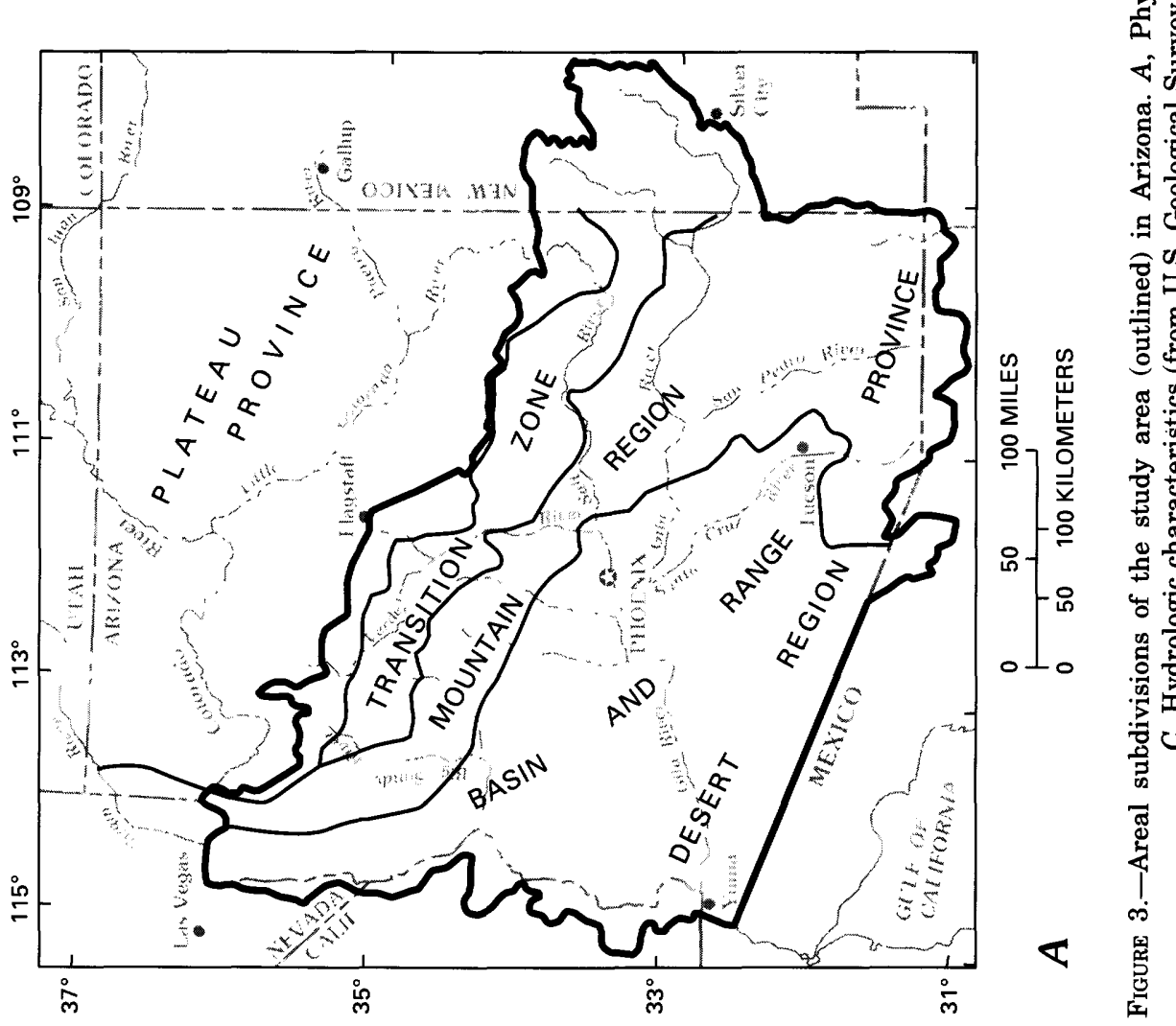


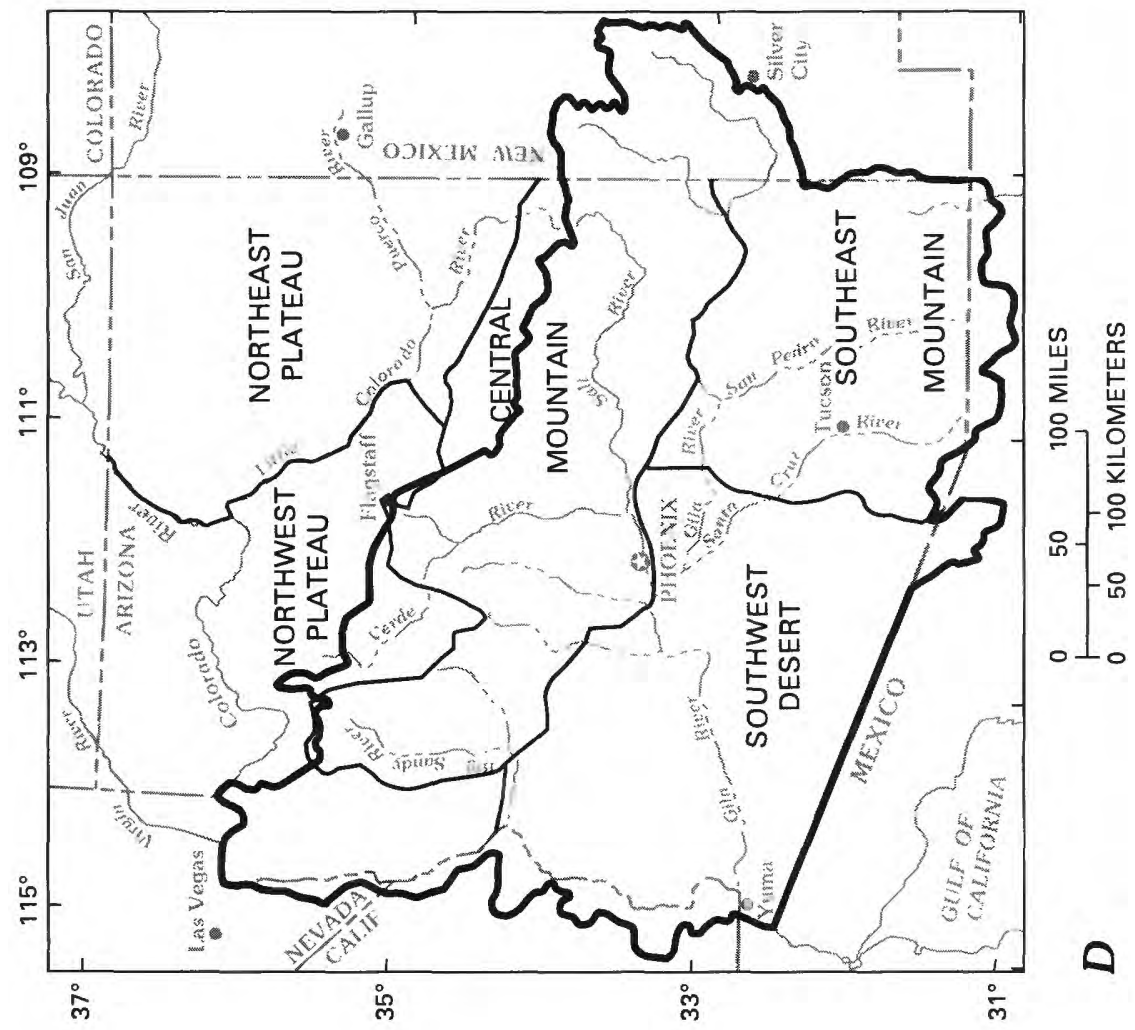

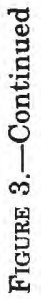

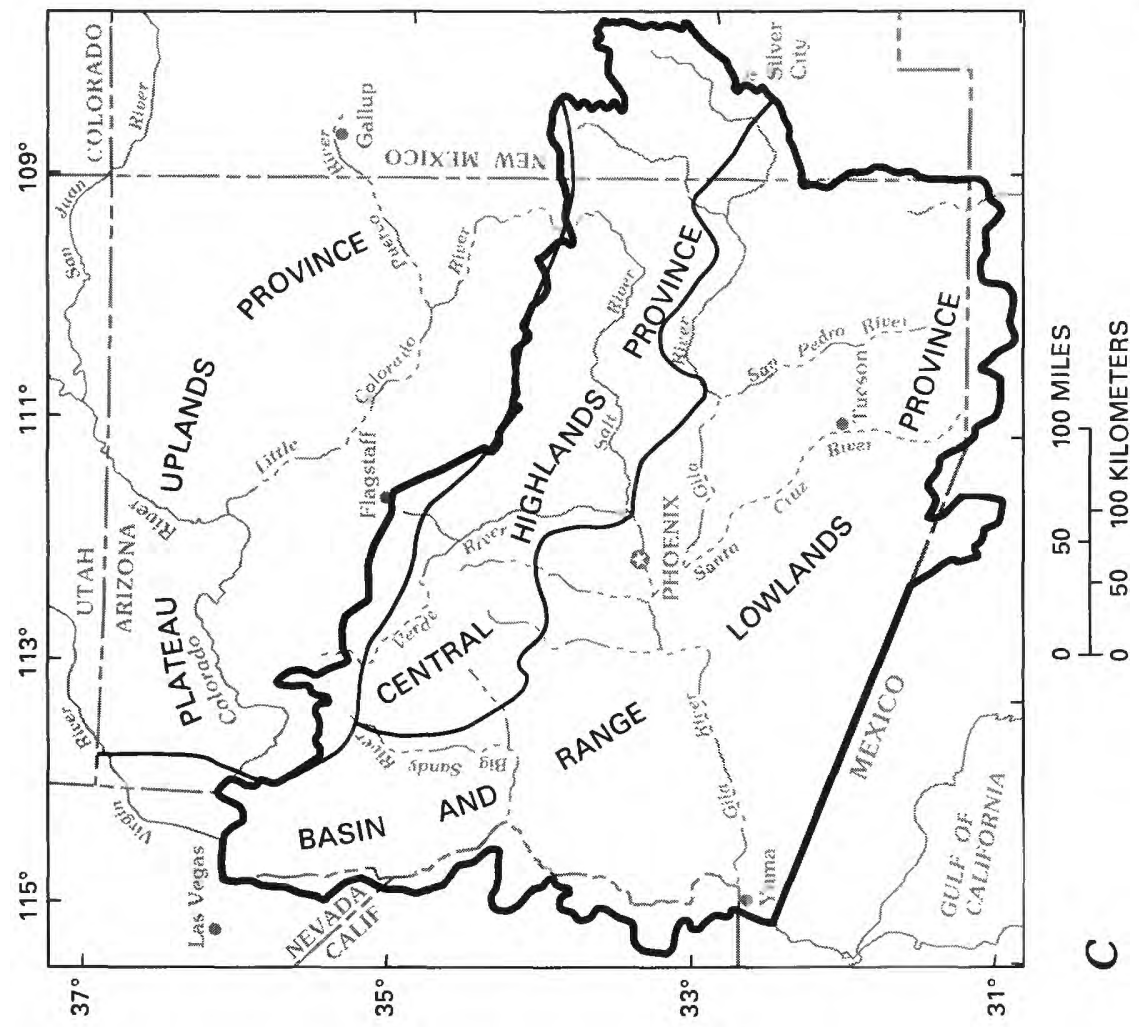


shape, water-table conditions, and subsurface stratigraphy. Five geophysical methods were usedsurface gravity, surface resistivity, seismic reflection and refraction, borehole gravity, and standard borehole-geophysical logging. The methods were tested in areas where geohydrologic data were available to evaluate the degree of accuracy of using the geophysical method to identify the geohy- drologic features. Areas where the various geophysical methods were used are shown in figure 5 .

Surface-gravity data were used to construct a first approximation of the depth-to-bedrock map for most of the study area (Oppenheimer and Sumner, 1981). The map was used to define regional similarities, differences, or trends in the physical size and shape of the basins. Assumptions and limita-

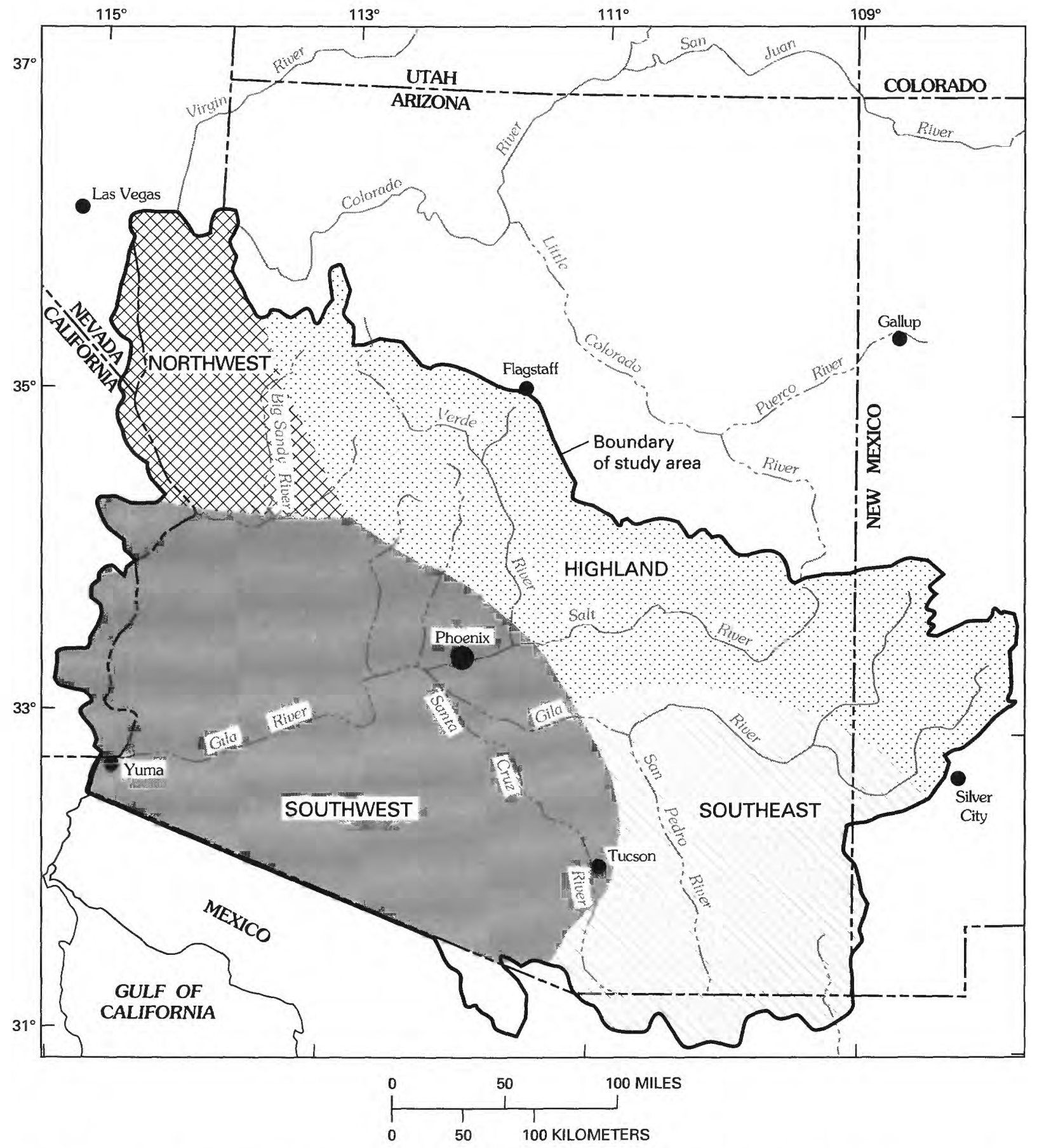

FIGURE 4.-General subdivisions of the study area based on climatic, physiographic, and hydrologic characteristics and geologic structure. 
TABLE 1.-Climatic characteristics of the study area

$[<$, less than; $>$, greater than $]$

\begin{tabular}{|c|c|c|c|c|}
\hline \multirow[b]{2}{*}{ Area $^{1}$} & \multicolumn{3}{|c|}{ Climate } & \multirow[b]{2}{*}{ Remarks } \\
\hline & Type & $\begin{array}{l}\text { Precipitation, } \\
\text { in inches } \\
\text { per year }\end{array}$ & $\begin{array}{l}\text { Lake evaporation, } \\
\text { in feet } \\
\text { per year }\end{array}$ & \\
\hline Southwest & Arid & $<12$ & $>6$ & $\begin{array}{l}\text { Growing season is longer } \\
\text { than } 9 \text { months; most } \\
\text { precipitation occurs } \\
\text { in winter. }\end{array}$ \\
\hline Southeast & Semiarid & $>12$ & 5-5.5 & $\begin{array}{l}\text { Growing season is } 6-9 \\
\text { months long; most } \\
\text { precipitation occurs } \\
\text { in summer. }\end{array}$ \\
\hline Northwest & Arid & $<12$ & $>6$ & $\begin{array}{l}\text { Shorter growing season } \\
\text { than southwest area } \\
\text { because of lower } \\
\text { temperatures; most } \\
\text { precipitation occurs } \\
\text { in winter. }\end{array}$ \\
\hline Highland & Semiarid & $16-32$ & $<5$ & $\begin{array}{l}\text { Low temperatures and } \\
\text { short growing season; } \\
\text { most precipitation } \\
\text { in summer; winter } \\
\text { precipitation may fall } \\
\text { as snow. }\end{array}$ \\
\hline
\end{tabular}

${ }^{1}$ See figure 4 for extent of area.

tions were the same throughout the area; however, density of data points was highly variable.

The interpretation of surface-gravity data to determine the depth to bedrock was greatly influenced by the assumed density contrasts between the sediments and the underlying bedrock material. Borehole-gravity data were obtained in six wells in four basins to obtain subsurface density data and to evaluate the validity of this constant-density contrast assumption. A generalized depth-density relation developed for the upper $1,200 \mathrm{ft}$ of sediments in the central part of the basins (Tucci and others, 1982) was similar to depth-density relations for similar deposits developed by other investigations in parts of Arizona and Nevada (Tucci and others, 1983).

Surface-resistivity data were obtained in the Tucson basin and Avra Valley (fig. 5) to delineate subsurface stratigraphy and to evaluate watertable conditions (Tucci, 1984). Interpretations were compared to available geohydrologic data to evaluate the surface-resistivity reliability. Seismic refraction and reflection data also were used to determine subsurface stratigraphy, hardrockalluvium contact, and water-table conditions. In addition, a single-conductor borehole geophysical logger was used in several wells. Logs included caliper, natural gamma, gamma-gamma, neutron, spontaneous potential, and single-point resistance. The data collected during the study, plus data available from other sources, were used to delineate subsurface stratigraphy and to evaluate hydraulic properties.

\section{GROUND-WATER CHEMISTRY}

The spatial distribution of chemical constituents in ground water, sources of dissolved species, and their chemical process were evaluated and interpreted. The evaluation was made through a review of existing data and field-sampling for major, minor, and trace elements and radioactive and stable isotopes. The geochemical interpretation provided additional and supportive information on ground-water flow in the basin aquifers. To achieve project goals on a regional basis, investigations and sampling programs were conducted in more than 20 basins. The basins selected had different hydrologic regimes on the basis of precipitation, recharge, and discharge; size and shape of the basin; geology of surrounding 

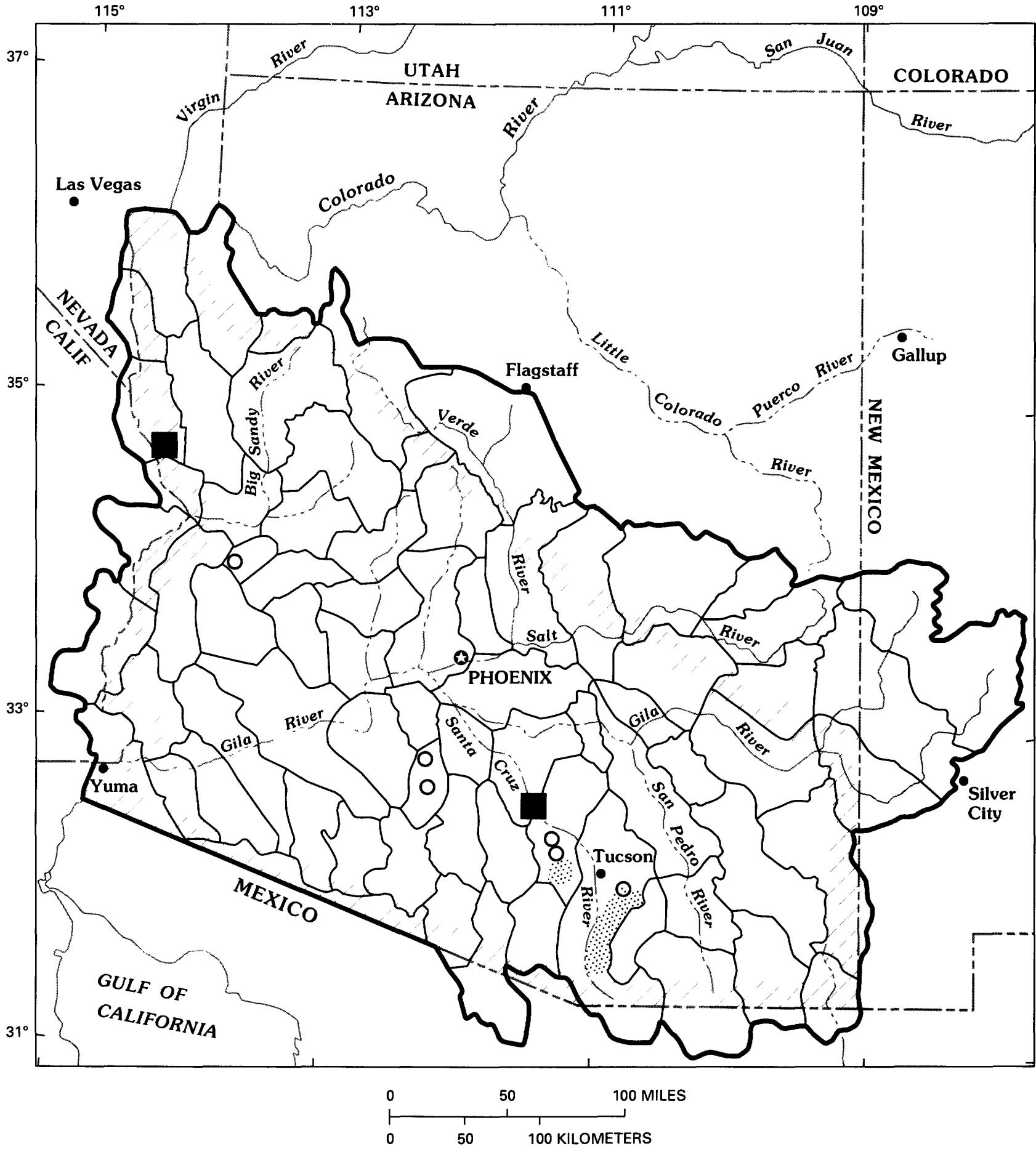

EXPLANATION

O BOREHOLE-GRAVITY SITE APPROXIMATE BOUNDARY OF
GRAVITY-MODELING STUDY AREA OF SEISMIC STUDY AREA OF RESISTIVITY STUDY BASIN BOUNDARY BOUNDARY OF STUDY AREA

FIGURE 5.-Areas of application of various geophysical methods. 
mountains; and composition of alluvial deposits within the basins.

Water samples were collected from about 500 wells. Quality control included replicate analyses of about 10 percent of the samples; in the case of the stable isotopes-deuterium and oxygen-18-a 100percent duplication of the analyses was done. Selected well cuttings and cores were analyzed for bulk and clay mineralogy and for chemical composition. The computer program WATEQ2 (Ball and others, 1980) was used to calculate equilibrium relations of the aqueous and mineral phases. Major ion and trace-element data were analyzed by linearregression analysis to determine statistical significance between variables. Readers interested in water quality and its related geochemistry can refer to Professional Paper 1406-C (Robertson, 1991). The geohydrologic framework of the basin aquifers and the related hydrology described in this report were defined on the basis of intercorrelation among the geologic, hydrologic, and geochemical information.

\section{GEOHYDROLOGY}

The basins and ranges were formed during the Basin and Range disturbance (Scarborough and Peirce, 1978 , p. 253). Movement along high-angle normal faults, which generally followed existing zones of structural weakness, resulted in rock displacements of more than $11,000 \mathrm{ft}$ in some areas (Scarborough and Peirce, 1978 , p. 257-258). The Basin and Range disturbance began 15 to 12 million years (m.y.) ago in the western part of the study area and 12 to 10 m.y. ago in the eastern part. Major basin subsidence essentially ended 10 to $6 \mathrm{~m}$.y. ago and 6 to $4 \mathrm{~m}$.y. ago in the western and eastern parts of the study area, respectively (Shafiqullah and others, 1980; Scarborough and Peirce, 1978; Eberly and Stanley, 1978). Tectonic activity continued on a minor scale in the eastern part of the study area into historic times (Morrison and others, 1981; DuBois and Smith, 1980). The western part of the study area has apparently remained tectonically inactive over the past few million years, although tectonic activity associated with the San Andreas fault system continues in the Yuma area (Shafiqullah and others, 1980; Tucker, 1980; Morrison and others, 1981). The areal variations in the timing of the tectonic events and regional variations in the structural deformation together with climatic differences resulted in different basin-geometry and basin-sediment characteristics across the study area.

Basin shape varies in the study area: The basins in the southeastern and northwestern parts tend to be elongated; most basins in the western and southwestern parts are oval in shape. Basins generally are oriented in a north to northwest direction. On the basis of gravity-modeling results (Oppenheimer and Sumner, 1981), the deepest basins are in a northwestto southeast-trending zone adjacent to the transition zone shown in figure $3 B$. The deepest basins are in the area defined as the "Gila Low" by Peirce (1974). This area has been a center of deposition since the Basin and Range disturbance and, to a large extent, continues as such today.

Although each basin is unique in shape, properties of the sediments that control ground-water flow are similar because the basins evolved in a similar manner. For the purpose of discussing the geohydrology of the study area, three principal units are defined: (1) rocks of the mountains, (2) pre-Basin and Range sediments, and (3) basin-fill sediments. For practical purposes, the rocks of the mountain generally do not yield water and are boundaries to ground-water flow in the basins. Pre-Basin and Range sediments and basin-fill sediments make up the basin aquifers; however, these sediments may consist of one or more lithologic units that are hydraulically connected and can be considered as a single aquifer.

\section{ROCKS OF THE MOUNTAINS}

The rocks that form the mountains consist of igneous, metamorphic, and sedimentary rocks that range in age from Precambrian to Cenozoic (Wilson and others, 1969; Dane and Bachman, 1965). On the basis of type, age, and hydrologic characteristics, the rocks can be divided into three general groups: (1) pre-middle Tertiary sedimentary rocks, (2) premiddle Tertiary crystalline rocks, and (3) middle Tertiary and younger volcanic and sedimentary rocks (pl. 1).

The pre-middle Tertiary sedimentary rocks are not as abundant as the pre-middle Tertiary crystalline rocks and consist of Paleozoic and Mesozoic sedimentary rocks. Paleozoic rocks occur mainly along the north boundary of the study area and in southeastern Arizona. Small, scattered outcrops also occur in west-central Arizona but are rare in the southwestern part of the study area. Sedimentary rocks of late Mesozoic age of continental origin are widely distributed throughout the western part (Reynolds, 1980, p. 5; Robison, 1980). Thick sequences of marine and continental Mesozoic rocks also occur in southeastern Arizona (Hayes and Drewes, 1978). Pre-middle Tertiary crystalline rocks are widely distributed and consist of igneous and metamorphic 
rocks of Precambrian, Mesozoic, and early Tertiary age.

Middle Tertiary and younger volcanic rocks are distributed throughout the study area. On the basis of hydrologic characteristics, these rocks are considered as a single group for purposes of this study; however, geologic differences within this group are distinct (Shafiqullah and others, 1980). The older middle Tertiary volcanics generally are felsic and intermediate in composition and may be highly deformed. These rocks are associated with pre-Basin and Range orogenic events (Shafiqullah and others, 1980 ). The younger volcanics generally are of basaltic composition, are often undeformed, and may also include some Tertiary sediments.

\section{PRE-BASIN AND RANGE SEDIMENTS}

Pre-Basin and Range sediments were deposited before the Basin and Range disturbance and probably occur in most of the study area. Pre-Basin and Range sediments are Tertiary in age and locally may range in age from Eocene to Miocene (Eberly and Stanley, 1978, p. 929). These sediments, which overlie erosional bedrock surfaces, consist of moderately to highly consolidated continental deposits that range in composition from silt, clay, and claystone to gravel and conglomerate. Facies distribution, paleodrainage directions, and clasts within the pre-Basin and Range sediments indicate source areas other than the mountains that presently surround the basin (Cooley and Davidson, 1963). In outcrops, preBasin and Range sediments generally are tilted and may dip at angles of more than $30^{\circ}$. Typically, an angular unconformity is seen between the pre-Basin and Range sediments and the overlying basin-fill sediments (fig. 6). Thicknesses of pre-Basin and Range sediments in outcrops generaily exceed several thousand feet, and much greater thicknesses may occur at depth.

The relative geologic age of the pre-Basin and Range sediments compared to younger sediments is supported by (1) displacement of the deposits by high-angle, normal faults associated with the Basin and Range disturbance (Eberly and Stanley, 1978) and (2) facies distribution, paleo-drainage directions, and the presence of clasts in the sediments that indicate source areas other than the mountains that presently surround the basin (Cooley, 1977; Cooley and Davidson, 1963; Davidson, 1973, p. 18). Because these characteristics are difficult to distinguish or are not evident in lithologic logs, the location of the pre-Basin and Range sediments in the subsurface is tentative in many basins where few data are available. The overlying basin-fill sediments near the contact with the pre-Basin and Range sediments typically may be lithologically similar to the preBasin and Range sediments because of the reworking of those pre-Basin and Range sediments during deposition of the basin-fill sediments.

On the basis of seismic data, Eberly and Stanley (1978) indicate a wide subsurface distribution of preBasin and Range deposits in western and central Arizona. Data from well cuttings and the presence of extensive outcrops in southeastern Arizona indicate that pre-Basin and Range deposits also are areally extensive within the basins.

Pre-Basin and Range sediments commonly are several thousand feet thick where exposed. The maximum estimated thickness for these deposits is 15,000 ft near Fort Huachuca (Brown and others, 1966 , p. 14). The thickest deposits are found in a northwest-trending zone that extends from the Huachuca Mountains in southeastern Arizona to the Artillery Mountains in west-central Arizona. Because these deposits generally occur at depths of several thousand feet in the basins, few wells penetrate the full thickness. Therefore, information on the subsurface thickness and facies distribution of the pre-Basin and Range sediments is sparse. However, seismic data (Eberly and Stanley, 1978) and data from several scattered deep exploration wells indicate that the subsurface thicknesses of the pre-Basin and Range deposits probably are less than 5,000 ft.

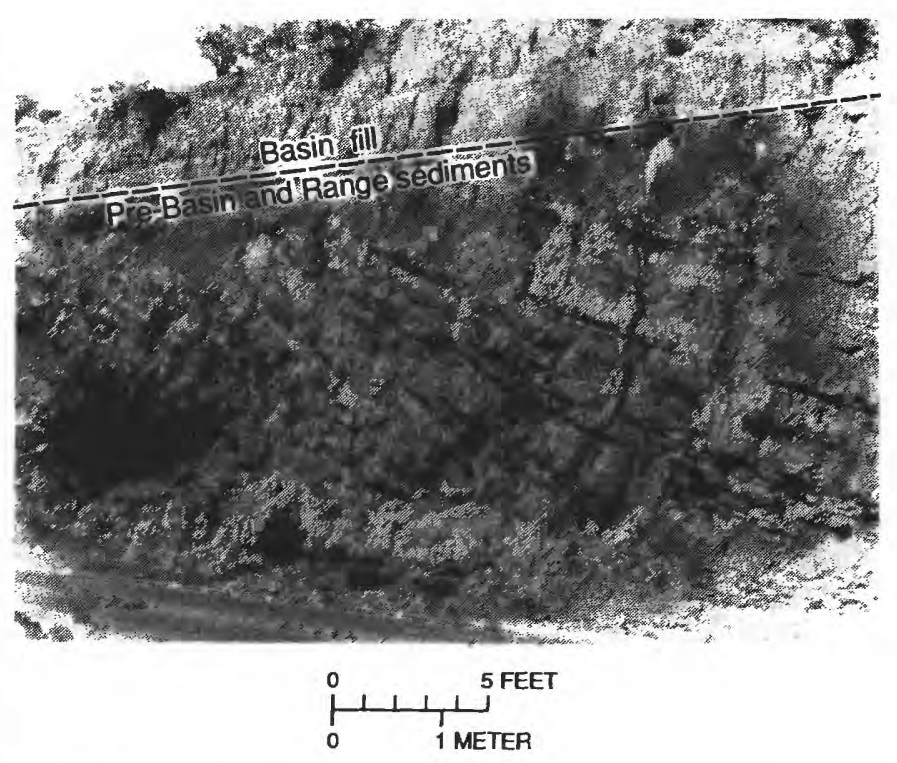

FIGURE 6.-Tilted pre-Basin and Range sediments overlain by basin fill near Tucson. 
Within the pre-Basin and Range sediments, the facies distribution is dependent on drainage patterns that are not related to present drainages. For example, the facies distribution within the middle Tertiary Pantano Formation (Finnell, 1970) near Tucson indicates that a center of deposition, and therefore the location of the bulk of the fine-grained sediments, may have been far to the east of the present basin center (Davidson, 1973, p. 19). In most other basins, however, data are not available to determine or estimate the facies distribution within the preBasin and Range deposits.

\section{BASIN-FILL SEDIMENTS}

The basins are filled with several thousand feet of sediments. Basin subsidence and internal deposition of these sediments occurred at different rates throughout the area; therefore, the thickness, areal extent, and grain size of the sediments are variable. Sedimentary deposits within groups of basins can be subdivided into units that reflect different depositional conditions. Spatial patterns in the character, thickness, and extent of the units differ among groups of basins and indicate different tectonic and depositional conditions.

Basin-fill sediments were deposited in the basins formed by the Basin and Range disturbance and range in age from late Tertiary to Quaternary (Scarborough and Peirce, 1978, p. 258). Sediments generally consist of weakly to highly consolidated gravel, sand, silt, and clay; however, they also include interbedded evaporite deposits and volcanic rocks in places. Basin-fill sediments unconformably overlie the pre-Basin and Range sediments. Clast types in the basin-fill sediments generally indicate a local source area.

Many investigators have divided the basin-fill sediments into two or more units on the basis of grain size, color, degree of consolidation or deformation, stratigraphic position, clast type, and water-bearing characteristics (Brown and others, 1966; Gillespie and Bentley, 1971; Davidson, 1973; U.S. Bureau of Reclamation, 1977a, b; Cooley, 1977; Menges and McFadden, 1981; Laney and Hahn, 1986). For purposes of this study, the basin-fill sediments that overlie the preBasin and Range sediments are divided into three general units: (1) lower basin fill, (2) upper basin fill, and (3) stream alluvium (fig. 7).

Generally, the lower basin-fill unit is more highly consolidated, deformed, and finer grained than the upper basin-fill unit. Mudstone and evaporite deposits are common in deep basins associated with the lower basin fill and generally do not occur in the upper basin fill. The age of the lower basin fill ranges from middle to late Miocene (about 15 to 8 m.y. ago) ${ }^{1}$, whereas the age of the upper basin fill ranges from late Miocene to late Pliocene (about 8 to 3 m.y. ago) ${ }^{1}$ (Brown and others, 1966, p. 1516; Davidson, 1973, p. 21 and 27; Menges and McFadden, 1981, p. 154; Shafiqullah and others, 1980). Lower basin fill generally represents deposition in topographically closed basins, and upper basin fill generally represents a transition period from a closed basin to integrated drainage basins.

Substantial differences in hydraulic characteristics between upper and lower basin fill are a result of different depositional environments. The basin-fill sediments generally are flat lying, although older parts of basin fill may be tilted $10^{\circ}$ to $15^{\circ}$ in outcrop areas and may be faulted like the pre-Basin and Range rocks (Cooley, 1977). Basin fill generally is more than $1,000 \mathrm{ft}$ thick; thicknesses may range from several hundred feet to more than $9,000 \mathrm{ft}$.

The basin-fill sediments are mainly of continental origin, although estuarine deposits occur along the Colorado River. Lithology and facies distribution of the basin-fill sediments indicate that the early stages of deposition (lower basin fill) occurred in topographically closed basins. Drainage gradually became integrated during the latter stages of deposition and appears to have been integrated earlier in the western part of the study area than in the central and eastern parts.

Basin-fill sediments have a varied and distinct facies distribution and consist mainly of weakly to moderately consolidated gravel, sand, silt, and clay that occur as distinct layers or poorly sorted mixtures. The deposits generally consist of poorly sorted gravel, sand, and some silt at the basin margins that grade, often abruptly, to sand, silt, and clay toward the basin centers. The percentage of fine-grained material (less than $0.0625 \mathrm{~mm}$ in diameter) generally is about 10 to 50 percent near the basin margins and 60 to 90 percent at the basin centers.

Stream alluvium, which overlies the basin-fill sediments, was deposited after the establishment of the present surface-drainage system. Stream alluvium consists of flood-plain material, channel deposits, terrace gravels, eolian sands, alluvial-fan deposits, and lacustrine and playa deposits. Lithology ranges from boulder and cobble gravel in the alluvial fans to clay in the lacustrine deposits. Clasts within stream alluvium commonly contain rounded gravel from

${ }^{1}$ Prior to 1983 , the time of a Miocene-Pliocene contact was defined as about 10 m.y. ago. 
DESCRIPTION OF PRINCIPAL HYDROGEOLOGIC UNITS

\begin{tabular}{|c|c|c|c|}
\hline Unit & Lithology & $\begin{array}{l}\text { Range in } \\
\text { thickness, } \\
\text { in feet }\end{array}$ & $\begin{array}{l}\text { Range in hydrologic } \\
\text { properties }\end{array}$ \\
\hline Stream alluvium & $\begin{array}{l}\text { Unconsolidated alluvial deposits along major streams and washes; } \\
\text { ranges from boulders and gravel to minor amounts of lacustrine } \\
\text { clay; typically consists of well-sorted sandy gravel with some silt }\end{array}$ & $0-<300$ & $\begin{array}{l}\text { Only locally saturated } \\
\text { Hydraulic conductivity, } \\
30-1,000 \text { feet per day } \\
\text { Specific yield, } \\
15-25 \text { percent }\end{array}$ \\
\hline $\begin{array}{l}\text { Upper basin } \\
\text { fill }\end{array}$ & $\begin{array}{l}\text { Unconsolidated to moderately consolidated alluvial deposits. Grades } \\
\text { from coarse- to fine-grained sediments toward the center of most } \\
\text { basins; includes basin-center facies with greater than } 60 \text { percent } \\
\text { fine-grained silt and clay; also includes lake deposits and basalt } \\
\text { flows in a few basins }\end{array}$ & $<100-1,000$ & $\begin{array}{l}\text { Hydraulic conductivity, } \\
1-100 \text { feet per day } \\
\text { Specific yield, } \\
3-25 \text { percent }\end{array}$ \\
\hline \multirow[t]{4}{*}{$\begin{array}{l}\text { Lower basin } \\
\text { fill }\end{array}$} & $\begin{array}{l}\text { Weakly to highly consolidated gravel, sand, silt, and clay and in } \\
\text { places contains interbedded to massive evaporites and volcanic } \\
\text { rocks }\end{array}$ & & $\begin{array}{l}\text { Hydraulic conductivity, } \\
1-50 \text { feet per day }\end{array}$ \\
\hline & $\begin{array}{l}\text { - Weakly to highly consolidated fanglomerate and alluvial deposits } \\
\text { found on the perimeter of most basins. In some places grades } \\
\text { rapidly into the fine-grained facies near major basin faults; underlies } \\
\text { the fine-grained facies in extensive areas of many basins }\end{array}$ & $0-1,000$ & $\begin{array}{l}\text { Storage coefficient, } \\
10^{-1} \text { to } 10^{-5}\end{array}$ \\
\hline & $\begin{array}{l}\text {-Basin-center fine-grained facies, weakly to moderately consolidated } \\
\text { silt and clay, generally } 55 \text { to } 80 \text { percent fine-grained sediments; } \\
\text { contains few evaporite deposits }\end{array}$ & $1,000-5,000$ & \\
\hline & $\begin{array}{l}\text {-Basin-center fine-grained facies, moderately consolidated silt and } \\
\text { clay, greater than } 80 \text { percent fine-grained sediments; gypsiferous } \\
\text { in many places. Includes extensively interbedded or massive } \\
\text { evaporites and interbedded volcanics in a few basins }\end{array}$ & $<1,000$ & \\
\hline $\begin{array}{l}\text { Pre-Basin and } \\
\text { Range sediments }\end{array}$ & $\begin{array}{l}\text { Moderately to highly consolidated fanglomerate and alluvial deposits } \\
\text { and interbedded volcanics that are structurally disturbed. Range } \\
\text { in composition from silt, clay, claystone, and limestone to gravel } \\
\text { and conglomerate and includes interbedded volcanics in places }\end{array}$ & $<1,000-15,000$ & $\begin{array}{l}\text { Hydraulic conductivity, } \\
1-13 \text { feet per day } \\
\text { Storage coefficient, } \\
10^{-2} \text { to } 6 \times 10^{-5}\end{array}$ \\
\hline $\begin{array}{l}\text { Bedrock of the } \\
\text { mountains }\end{array}$ & Igneous, metamorphic, and sedimentary rocks & & \\
\hline
\end{tabular}

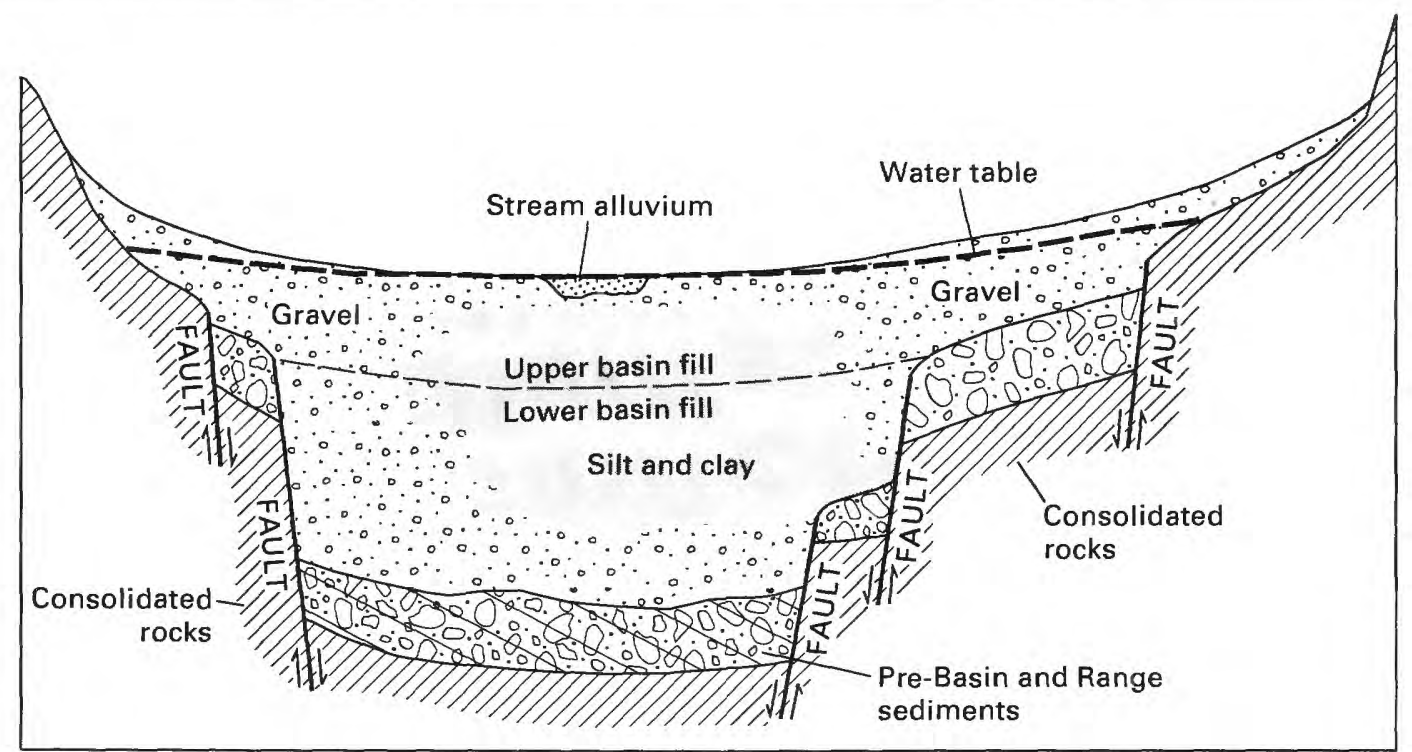

Not to scale

Figure 7.-Generalized section and description of principal hydrogeologic units of basins of the study area. 
areas outside the surrounding basin. Stream alluvium generally is unconsolidated, except where cemented with caliche, and generally is undeformed. The stream alluvium ranges in age from late Pliocene to Holocene (Davidson, 1973, p. 31-32; Schreiber, 1978, p. 281).

\section{LOWER BASIN FILL}

During this study, the lower basin-fill sediments are divided into two groups on the basis of differences in the fine-grained facies. They are (1) a very fine grained silt or clay facies with gypsiferous mudstones and massive evaporite deposits and (2) a moderately fine grained sand, silt, and clay facies. The areal extent differs for each group, and many basins have sediments of both groups (fig. 8).

Extensive and thick sequences of lower basin fill were deposited in a playa environment and consist of 80 - to 100 -percent very fine grained material in the basin centers of the central, southeastern, and a few northwestern basins. The basins were actively subsiding at the time the sediments were being deposited. The massive evaporites included in some of the central basins and in some basins adjacent to the Colorado Plateau may indicate that these basins received significant local drainage for an extended period of time. Gypsiferous mudstones are found above and below the evaporites and at correlative depths in some basins in which massive evaporites are not present.

The evaporite and mudstone deposits typically are a few thousand feet thick and generally occur in the deeper parts of the basins. Toward the basin margins, changes from mudstone to a coarser grained material may be gradational or abrupt owing to faulting; however, the relations are difficult to define because of the paucity of data.

Some coarse-grained sediments also are found beneath the fine-grained material in many basins. These sediments may have been deposited prior to or during the earliest stages of the Basin and Range disturbance and the development of closed basins. In shallow basins, these sediments may be an important water-bearing unit.

A moderately fine grained facies that contains 55to 80 -percent silt (material less than $0.0625 \mathrm{~mm}$ in diameter) is the principal fine-grained group in the western basins and overlies the 80 - to 100-percent very fine grained group in the central basins. The moderately fine grained facies of the lower basin fill contains few evaporite deposits. Deposition occurred under closed-basin conditions during late stages of basin subsidence and after subsidence had ended. This facies gradually changes from coarse to fine grained toward the basin center and generally is located basinward of major faults in the consolidated rocks where downdropping of lower basin fill has occurred. The moderately fine grained facies is more areally extensive in the central basins, where it overlies the very fine grained facies that contains gypsiferous mudstone and massive evaporites, than in the western or eastern basins. The moderately fine grained facies of the lower basin fill generally is thin-less than $1,000 \mathrm{ft}$ thick in the central basins and less than $500 \mathrm{ft}$ thick in the western basins. This facies generally overlies coarse-grained sediments that may be a part of preBasin and Range sediments.

\section{UPPER BASIN FILI}

The upper basin fill was deposited during the last stages of basin infilling and the transition from closed basins to integrated drainage basins, although significant fine-grained facies, indicative of a closedbasin environment, are present in the central basins. The change from lower to upper basin-fill deposition was caused by tectonic adjustment, climatic changes during the Pleistocene, changing base levels-both regional and local-and infilling of basins. Menges and McFadden (1981, p. 158) stated that "the upper basin fill may best be viewed as a 'last gasp' basin sedimentation developed primarily as a lag response to mountain-valley relief inherited from the earlier, now largely quiescent, Basin and Range disturbance." The presence of the extension of the Gulf of California into the lower Colorado River area and its subsequent removal may have affected the base level for drainage, especially in western Arizona. Upper basin fill generally is undeformed and tilted less than $5^{\circ}$ where exposed (Cooley, 1977). Displacement by faults, mainly in the southeastern part of the study area, is slight.

Upper basin fill generally is more coarse grained than lower basin fill. In the Tucson area, the Pleistocene Fort Lowell Formation contains 10 - to 50 percent fine-grained material in most of the basin. In the center of deposition, however, the fine-grained facies consists of about 75 percent material of silt or clay size (Davidson, 1973, p. 29). In contrast, the fine-grained facies of the "Tinaja beds," which is a lower basin-fill unit, contains 75 to 95 percent material of silt or clay size (Davidson, 1973, p. 23). Evaporite deposits that are commonly found in the fine-grained facies of the lower basin fill are conspicuously lacking in the upper basin fill. Upper 

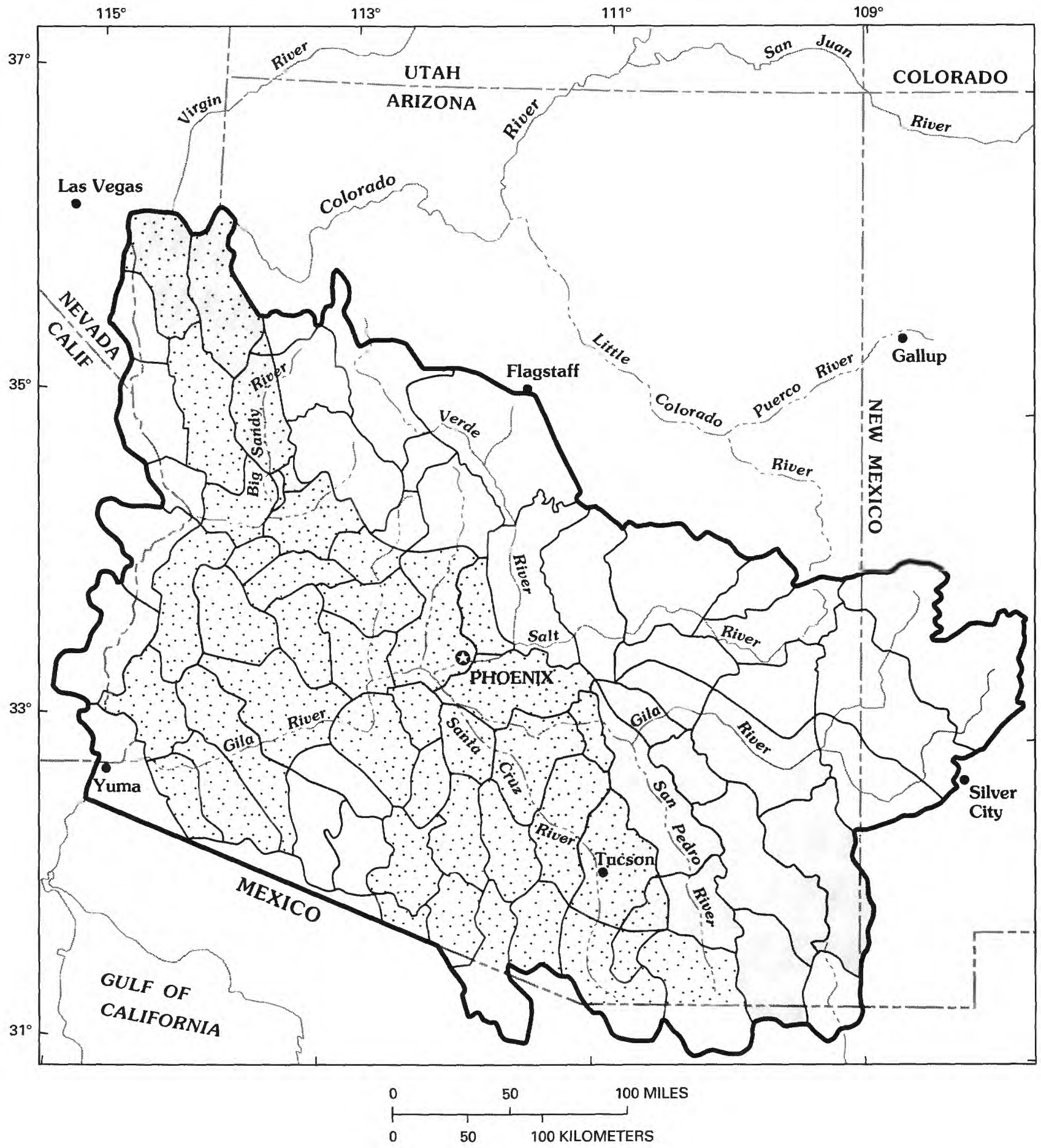

EXPLANATION

\section{LOWER BASIN-FILL SEDIMENT}

— Very fine grained ( 80 to 100 percent) with gypsiferous mudstone and massive evaporite deposits

Insufficient data or lower basin fill not present

$\because \because \quad$ Moderately fine grained (55 to 80 percent)

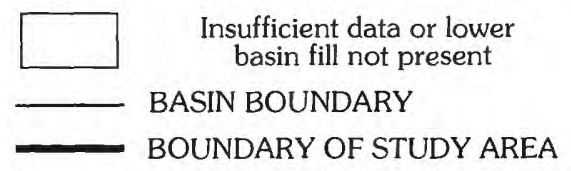

FiguRE 8.-Generalized areal extent of two groups of lower basin-fill sediments in the study area. 
basin fill is weakly consolidated to unconsolidated, although locally this unit may be tightly cemented with caliche (Davidson, 1973, p. 28-29).

Upper basin fill includes sediments deposited during the transition from closed basins to throughflowing or integrated drainage basins. The central basins contain sediments that were deposited under closed-basin drainage conditions and have a less extensive fine-grained facies than the underlying lower basin fill. These fine-grained sediments, which are less than $200 \mathrm{ft}$ thick, are overlain by coarser grained material that was deposited under an integrated-drainage environment.

The upper basin fill ranges in thickness from less than 100 to about $1,000 \mathrm{ft}$ but typically is 300 to 500 $\mathrm{ft}$ thick. The unit generally is less than $500 \mathrm{ft}$ thick in the western basins and 300 to $1,000 \mathrm{ft}$ thick in the central basins. Erosion has removed much of the upper basin fill in the southeastern basins; however, these deposits may be as much as 1,000 ft thick near Fort Huachuca (Brown and others, 1966). In the southeastern basins, upper basin fill consists of lacustrine and fluviolacustrine deposits of blue-green clays and some fresh-water limestone (Gray, 1965).

Marine-estaurine deposits that occur in the basins along the lower Colorado River are considered equivalent to the upper basin fill on the basis of the radiometric-age date of $5.5 \mathrm{~m}$.y. ago for the base of these deposits (Shafiquallah and others, 1980, p. 227). Marine beds of the mostly Pliocene Bouse Formation (Metzger, 1968) were deposited in an ancestral embayment of the Gulf of California. The Bouse Formation consists of a basal limestone overlain by interbedded clay, silt, and sand and a tufa (Metzger, 1968) and ranges in thickness from zero where removed by erosion to about $1,000 \mathrm{ft}$ in the Yuma area.

\section{STREAM ALLUVIUM}

Stream alluvium was deposited after filling of the basins and during the establishment of the present drainage system and consists of flood-plain, channel-fill, alluvial-fan, and playa deposits. The stream alluvium generally is unconsolidated except where cemented with caliche. Grain size ranges from boulder and cobble gravel in the alluvial fans to clay in the playa deposits but consists mainly of sand and gravel along the stream channels.

Stream alluvium generally was deposited during and after through-flowing basin drainages were established. Flood-plain alluvium and channel deposits may contain rounded gravel from areas outside the basin. These exotic gravels are particularly evident in the alluvium of the Colorado River (Bentley, 1979a, b, c; Metzger and others, 1973; Laney, 1979a, b, 1981) and in gravels deposited by the Salt River in the Phoenix area (Laney and Hahn, 1986). Lacustrine and playa deposits in closed basins-Willcox basin in the southeast and Hualapai Valley in the northwest-are included with the basin-fill sediments during this study because of possible continuous deposition since the Basin and Range disturbance. The uppermost parts of the upper basin fill probably are equivalent to the stream alluvium; however, because deposition was largely continuous, no attempt was made to subdivide a unit that is the age equivalent to the stream alluvium.

Although the stream alluvium generally forms a thin cover over the basin-fill deposits, the unit has the greatest hydrologic significance where it occurs in the flood plains of present streams. The thickness of the unit generally is $100 \mathrm{ft}$ or less, although a maximum thickness of $600 \mathrm{ft}$ is reported in the Yuma area (Cooley, 1977). Above-average thicknesses of 200 to $300 \mathrm{ft}$ also are present in the Phoenix area (Laney and Hahn, 1986).

Stream alluvium generally is undeformed, although it may have been cut by normal faults in some areas, particularly in the Mexican Highland section (Morrison and others, 1981). The unit also has been subjected to regional uplift in eastern Arizona and subsidence in central and extreme southeastern Arizona (Morrison and others, 1981, fig. 1; Péwé, 1978). Although stream alluvium is dissected along nearly all stream courses, the unit has undergone limited dissection in the Mexican Highland section and generally is undissected in the Sonoran Desert section (Cooley, 1977).

\section{OCCURRENCE AND MOVEMENT OF GROUND WATER}

Principal aquifers of the study area are contained in the basins and are composed of unconsolidated to semiconsolidated clastic deposits. Poland and others (1972, p. 2) define an aquifer system as "A heterogeneous body of intercalated permeable and poorly permeable material that functions regionally as a water-yielding hydraulic unit; it comprises two or more permeable beds separated at least locally by aquitards that impede ground-water movement but do not greatly affect the regional hydraulic continuity of the system." The basins are connected in a dendritic pattern, similar to the surface drainage, to form an integrated regional flow system. Aquifers 
mainly serve as reservoirs with water being stored in the pores of the basin sediments. The basin aquifers are hydraulically interconnected through small areas of alluvium and ground water flows from basins of higher altitude to basins of lower altitude.

\section{GROUND-WATER CONDITIONS}

Water generally occurs under unconfined conditions in the basin aquifers, although, in places, confined conditions may occur with depth (Davidson, 1979 , p. 6). Confined conditions occur where extensive fine-grained facies of the basin fill overlie coarser grained facies, such as in parts of the San Pedro and San Simon Valleys (see pl. 1) and in parts of some basins in western Arizona. Confined conditions also may occur in basins where volcanic rocks overlie or are interbedded with basin-fill sediments, such as in Chino Valley (U.S. Bureau of Reclamation, 1974 , p. 58).

Depths to the water table range from at land surface near perennial streams to as much as $1,300 \mathrm{ft}$ below land surface in some basins near the mountain front. In places where confined conditions occur, near the center of basins, a few flowing wells were documented before development; however, the occurrences of flowing wells were not widespread.

\section{STRUCTURAL INFLUENCE}

Faults may influence the movement and quality of ground water within a basin. Facies distribution within the basin fill was influenced by the location of active faults during deposition. Most Quaternary faults that would affect the major water-bearing units are in the Mexican Highland physiographic section (Morrison and others, 1981). In general, the Sonoran Desert section has been tectonically inactive since Quaternary time (Morrison and others, 1981; Tucker, 1980). In most basins, faulting affects mainly the lower basin-fill deposits.

The thickness and type of the basin fill influence the movement, quantity, and quality of ground water and are directly related to the regional structure. Most deep basins-greater than $8,000 \mathrm{ft}$ deep-and the thickest sediments are in central Arizona in and near the Gila Low of Peirce (1974). Thick evaporite deposits associated with deep basins occur within basins that are adjacent to or within the Mexican Highland. Inflow of large quantities of water necessary for the accumulation of the existing thick evaporite deposits may have come from the adjacent highlands to the internally drained basins. Disseminated evaporite deposits generally are found within the fine-grained facies of the lower basin fill throughout the study area.

\section{INFLUENCE OF ROCK TYPE ON BASIN HYDROLOGY}

The hydrology of the alluvial basins is strongly influenced by the adjacent consolidated rocks. The rocks that form the mountains affect the rate and amount of runoff. Detritus that was eroded from the mountains and deposited in the basins affects the aquifer characteristics and the ground-water chemistry. The regional tectonic setting governs basin structure, orientation, and altitude, which in turn affect groundwater occurrence and movement.

Mountains that surround the basins were uplifted during the tectonic events associated with the Basin and Range disturbance. The unweathered crystalline and consolidated sedimentary rocks that form the mountains are flow boundaries of the basin aquifers owing to drastic contrast between the permeability of unweathered rocks and the permeability of the basin fill. The subsurface location of the unweathered rocks, therefore, effectively delineates the extent of the basin aquifer laterally and with depth. The lateral extent of the principal aquifer of a basin is controlled in many instances by the location of a pediment edge. In the west basins, pediments are extensively developed and buried by alluvium; therefore, the boundaries of the basin aquifers may be a considerable distance from the mountain fronts. The east basins do not have extensive buried pediments, and the boundaries of basin aquifers are close to the mountain fronts. In places, the unweathered but fractured crystalline rocks may yield a few tens of gallons per minute of water to domestic and stock wells. The amount of available water in these crystalline rocks is highly variable, and the location of reliable supplies is difficult to predict.

The mountains locally include consolidated sedimentary rocks that store and transmit water better than the crystalline rocks. Water in the consolidated sedimentary rocks is discharged to some basin aquifers along the Mogollon Rim from a sequence of sedimentary rocks that extends from the Colorado Plateau province. In the Verde Valley, water in the Paleozoic sedimentary rocks also discharges to the upper Tertiary Verde Formation or to the land surface through springs. Excessive ground water from consolidated sedimentary rocks (limestone) in the mines of the Tombstone area in southeastern Arizona was one of the major factors in the decline of that mining 
district, and Hollyday (1963) concluded that these sedimentary rocks could provide sufficient water for municipal use.

Altitudes of the mountains directly affect the amount of precipitation and recharge to a basin. Altitudes in the Mexican Highland generally are higher than those in the Sonoran Desert. Recharge from precipitation, therefore, is greater in the basins of the Mexican Highland. Nearly all the perennial streams in the study area are within the Mexican Highland with the exception of the Colorado River.

Volcanic rocks may be a local source of ground water. Occurrence and movement of ground water through volcanic rocks depend mainly on secondary permeability features, such as fractures and joints; however, brecciated parts of flows and interbedded sediments may also transmit water. Well yield, location, and dependability of the water supply generally are dependent on the existence and density of fractures. Heindl (1967) reported ground-water flow through fractured volcanic rocks on the Tohono O'Odham Indian Reservation (formerly the Papago Indian Reservation) of southern Arizona. Volcanic rocks provide the source for part of the municipal water supply for the City of Kingman, Arizona (Gillespie and Bentley, 1971). Trauger (1972) reported that the volcanic rocks of Grant County, New Mexico, may be a local source of ground water.

Basin fill that constitutes the principal aquifers of the study area is the most permeable unit and contains vast quantities of water in storage. The source of ground water in the area is precipitation either in the basins or in the watershed upstream from the basins. A large percentage of precipitation that falls on the area is subsequently lost to evapotranspiration; the remainder either runs off or infiltrates. Harshbarger and others $(1966$, p. 5) estimated that evapotranspiration depletes 95 percent of the total precipitation. Recharge, therefore, is limited. Recharge occurs as infiltration of precipitation where it falls or after it collects as runoff in stream channels. Runoff and its associated recharge occurs in perennial and ephemeral streams. Streams and rivers in the recharge areas that contain perennial flow provide a constant source of water to the basin aquifers. Ephemeral streams, which are dominant in the study area, provide a source of recharge during and for short times following runoff events.

\section{WATER-BEARING CHARACTERISTICS OF THE BASIN SEDIMENTS}

The water-bearing characteristics of the basin sediments are variable areally and vertically. In gen- eral, well yields tend to decrease with increasing depth. The stream alluvium is the most productive unit in the study area.

\section{PRE-BASIN AND RANGE SEDIMENTS}

The pre-Basin and Range sediments generally do not yield large quantities of water to wells because of their consolidated nature. These sediments are not continuous throughout the study area owing to faulting and provide only a local source of water, mainly near the basin margins where these sediments occur at shallow depths.

Because of the variable nature of these sediments in terms of lithology and degree of cementation, their hydraulic property is difficult to estimate. In the Tucson area, the pre-Basin and Range sediments (Pantano Formation) have hydraulic conductivities that range from 1 to $13 \mathrm{ft} / \mathrm{d}$ (Davidson, 1973, p. 19), and these values probably are typical for the preBasin and Range sediments. Recent work by Anderson (1988) indicates that many of the sediments designated by Davidson (1973) as Pantano Formation may be younger and more correctly assigned to the lower part of the Tinaja beds (informal designation). Davidson's reported hydraulic-conductivity values of the Pantano are still considered to be representative values of the pre-Basin and Range sediments. Hydraulic-conductivity values of pre-Basin and Range sediments in Vekol Valley range from 5 to $6 \mathrm{ft} / \mathrm{d}$ (Hollett and Marie, 1987, p. 13). Specific capacities range from 20 to $40(\mathrm{gal} / \mathrm{min}) / \mathrm{ft}$ of drawdown in wells that penetrate 500 to $1,000 \mathrm{ft}$ of the Pantano Formation. Porosity, which is calculated from borehole-geophysical logs, ranges from 20 to 27 percent, and storage coefficients computed from aquifer tests in wells that penetrate the Pantano Formation near the basin margin range from 0.01 to 0.001 . Storage coefficients for pre-Basin and Range sediments in Vekol Valley range from $2 \times 10^{-4}$ to $6 \times 10^{-5}$ (Hollett and Marie, 1987, p. 13).

The pre-Basin and Range sediments generally are not penetrated by wells except in areas near the basin margins because water is easily obtained in shallower sediments. Recharge to the pre-Basin and Range sediments by infiltration of runoff along the basin margins probably is small because of the high degree of consolidation. As water levels decline in the basin-fill sediments, the pre-Basin and Range sediments may become important. Available data, although sparse, indicate that the pre-Basin and Range sediments are widespread at depth in the study area and may contain large volumes of water 
in storage. Surface-resistivity data near Tucson indicate a potential aquifer, which may correlate to the pre-Basin and Range sediments, below the finegrained basin fill. This potential aquifer is more than $2,000 \mathrm{ft}$ deep.

\section{BASIN-FILL SEDIMENTS}

Most of the water is stored in the basin-fill sediments, which form the major aquifers in the study area. Basin-fill sediments include materials that were deposited under several depositional environments, have a wide range of grain size and degree of consolidation, and consequently have a wide range of hydraulic conductivity (about 1 to $100 \mathrm{ft} / \mathrm{d}$ ). The saturated thickness may be more than several thousand feet in some basins, although most water is obtained from the upper $1,000 \mathrm{ft}$. On the basis of hydrogeologic differences, the basin fill is divided into two units-the upper and lower basin fill; however, the units are hydraulically connected. The units differ in their hydraulic characteristics and water quality.

Lower basin fill generally yields less water than upper basin fill, although lower basin fill generally has a greater saturated thickness. Hydraulic conductivity of the lower basin fill ranges from less than 1 to about $50 \mathrm{ft} / \mathrm{d}$ and generally is less than $20 \mathrm{ft} / \mathrm{d}$ (fig. 7). Specific yields are 0.1 or less where the overlying deposits have been dewatered. Values for hydraulic conductivity and specific yield are much lower in the fine-grained sediments than in the coarse-grained sediments. Davidson (1973, p. 24) reported specific capacities of the Tinaja beds-a lower basin-fill equivalent in the Tucson basin-that ranged from about 1 to 40 ( $\mathrm{gal} / \mathrm{min}) / \mathrm{ft}$ of drawdown and porosity from geophysical logs that ranged from 25 to 35 percent. In the Hualapai and Sacramento Valleys in northwestern Arizona, specific capacities were estimated to be between 3 and $13(\mathrm{gal} / \mathrm{min}) / \mathrm{ft}$ of drawdown for lower basin-fill deposits (Gillespie and Bentley, 1971, p. 24). In the basins of western Arizona, the coarse-grained sediments yield more water than the overlying finegrained sediments in the lower basin fill. Transmissivity values of the coarse-grained sediments may be as much as $30,000 \mathrm{ft}^{2} / \mathrm{d}$ but generally average about 10,000 to $15,000 \mathrm{ft}^{2} / \mathrm{d}$. The fine-grained sediments generally do not yield large quantities of water but contain a large volume of water in storage that will drain slowly to more permeable deposits as water levels decline as a result of continued pumping. Massive evaporite deposits within the lower basin fill function as barriers to ground-water flow and tend to increase the salinity of ground water caused by dissolution of evaporites.

The upper basin fill generally has a greater transmissivity than does the lower basin fill because it is less consolidated and cemented and generally is coarser grained. Therefore, in central Arizona, the upper basin fill is a major part of the basin aquifers. In the western part of the study area, however, the upper basin fill generally is above the water table; in southeastern Arizona, the upper basin fill is fine grained and much of it has been removed by erosion.

Upper basin fill consists of weakly cemented clay, silt, sand, and gravel and is heterogeneous and anisotropic. An increase in fine-grained material will result in an associated decrease in hydraulic conductivity. The greatest amount of fine-grained material and the thickest part of the upper basin fill is in the deepest part of the basin, which indicates a closedbasin depositional environment. Deposits are coarser grained in the direction of the source area. The change in percentage of fine-grained material from the source area to the center of the basin is variable from basin to basin within equivalent units. The change in percentage of fine-grained material with distance from the mountain front in east Salt River Valley and in the Tucson basin for both the upper and lower basin fill is shown in figures $9 A-D$.

In east Salt River Valley, the percentage of finegrained material increases rapidly within a few miles of the hardrock-alluvium contact at the base of the Superstition Mountains (figs. 9A, B). Beginning at the base of the Santa Catalina Mountains in the Tucson basin, a gradual basinward increase in finegrained material extends throughout a 12-mile zone adjacent to the mountain front (figs. $9 C, D$ ). The difference in shape of the curves could be influenced by geologic differences of rocks in the source area or could be related to climatic or depositional environment such as drainage patterns. Because the upper basin fill generally is undeformed, the difference probably is not caused by faults.

Results of analyses of aquifer-test data in east Salt River Valley and Tucson basin indicate that the hydraulic conductivities are related to the percentage of fine-grained material. However, this relation is not constant but varies from basin to basin. For example, in east Salt River Valley (fig. $9 E$ ), hydraulic conductivity of the upper basin fill with fine-grained material less than about 55 percent generally is about 30 percent less than that for upper basin fill with the same percentage of fine-grained material in the Tucson basin (fig. 9F). The hydraulic-conductivity relation for the Tucson 
basin shown in figure 9 is based on a small sample and may be influenced by the presence of saturated stream alluvium. Textural differences such as angularity, packing, and cementation may also influence the relation.

Data are insufficient to compare the relation of percentage of fine-grained material and hydraulic conductivity of lower basin fill between basins. Comparison of the relation between the upper and lower basin fill in the Tucson basin (figs. $9 F, G$ ) indicates the lower, older material has a consistently lower hydraulic conductivity for an equal percentage of fine-grained material. The lower basin fill probably is less permeable because it is more compacted and cemented than the upper basin fill.

East Salt River Valley and the Tucson basin are the only areas for which data are adequate to explore the existence of relations among percentage of fine-grained material, distance from mountain fronts, and hydraulic conductivity. The areal applicability or general consistency of these relations in other basins is unknown. A comparison of the relations between the hydraulic conductivity and distance from mountain fronts for upper basin fill in east Salt River Valley and the Tucson basin shows a marked contrast in the curve shapes (figs. $9 H, I$ ). A difference is also shown in the distribution of percentage of finegrained sediments of the upper basin fill (figs. $9 E$, $F$ ) as a function of distance from the mountain-front boundary. In the Tucson basin, comparison of the relation of the upper and lower basin fill indicates that the curve shape of the percentage of fine-grained material and distance from mountain fronts (figs. $9 C, D$ ), and the curve shape of the hydraulic conductivity and distance from mountain fronts (figs. 9I, J) are similar. However, the magnitude of the hydraulic conductivity differs probably because of differences in compaction and cementation.
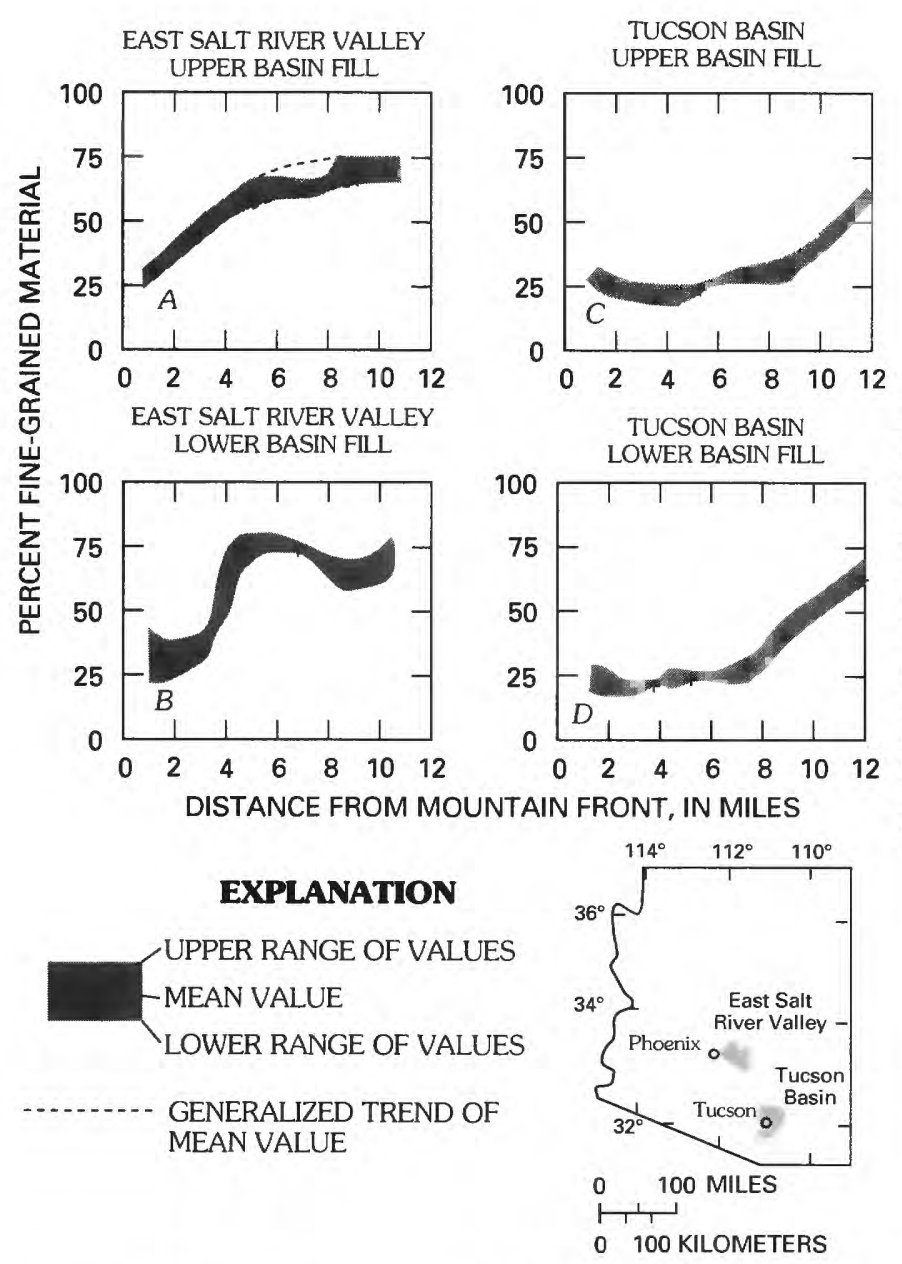

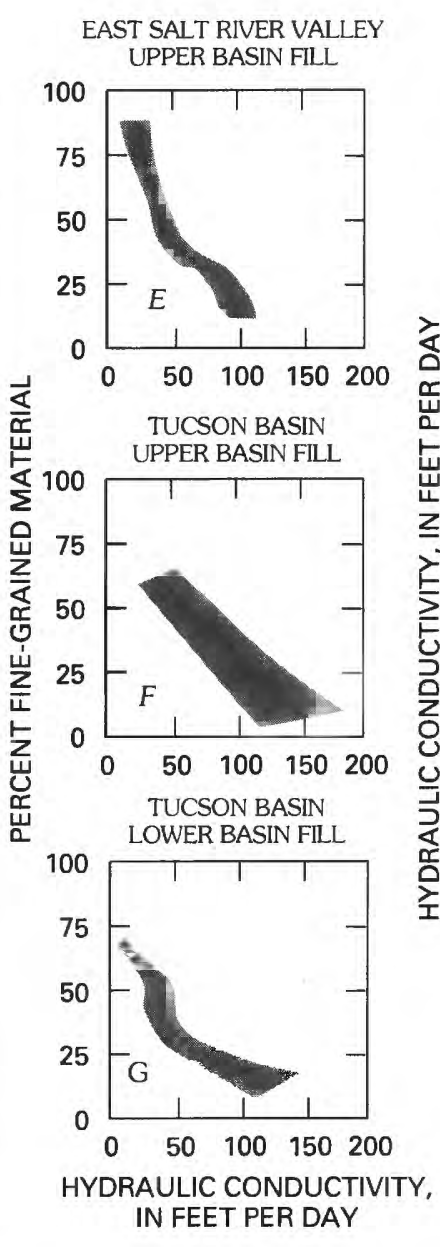

FIGURE 9.-Relation of percentage of fine-grained material in drilling samples, hydraulic conductivity, and distance from mountain front for basin fill in east Salt River Valley and the Tucson basin. 
Hydraulic conductivity of upper basin fill ranges from about 1 to more than $100 \mathrm{ft} / \mathrm{d}$. Hydraulicconductivity values of the upper basin fill in central Arizona generally are 30 to $90 \mathrm{ft} / \mathrm{d}$ on the basis of analyses of all aquifer-test data available to this study. In southeastern Arizona, these deposits generally are more fine grained than in central Arizona, and hydraulic-conductivity values of these sediments generally are less than $20 \mathrm{ft} / \mathrm{d}$. Values for specific yield are commonly between 0.10 and 0.15 but may range from 0.03 to 0.25 within a basin (fig. 7). Davidson $(1973$, p. 30$)$ reported that specific capacities range from 10 to $100(\mathrm{gal} / \mathrm{min}) / \mathrm{ft}$ of drawdown and porosities range from 26 to 30 percent in the Fort Lowell Formation, which is an upper basin-fill equivalent in the Tucson basin. As in the lower basin fill, values of hydraulic conductivity vary within the upper basin fill because of differences in lithology.

Specific-yield information is lacking. It is impractical to calculate the value of specific yield from any short duration aquifer-test data because of the effect of long-term delayed drainage. Waterbudget analyses have been used to estimate average values of specific yield. Results indicate a range of specific yield for the upper basin fill from 9 to 16 percent (Halpenny and others, 1952, table 3 ; White and others, 1966, p. 36). On the basis of analysis of basin-sediment characteristics, the range of specific yield in a basin probably is from about 3 to 25 percent.

Drillers' logs were used as a means of estimating the areal distribution of specific yield. The study was done under a contract developed with the Arizona Department of Water Resources (Evans and Haimson, 1982) and was a computerized version of a technique used and described by Davis and others (1959). Values of hydraulic conductivity and specific yield, based on laboratory analysis of drilling samples, were assigned to the various deposits described in the drillers' logs. Coarse-grained material was assigned a high value and fine-grained material was assigned a low value; intermediatesized material or a combination of all three types of material was assigned an intermediate value. For basins where the upper basin fill was the uppermost saturated zone, the resultant areal pattern showed low specific yield in the center of the basin and high specific yield near the basin margins.

Distinct lateral changes in grain size are common and may reflect facies changes or be the result of faulting in the lower basin fill. The areal pattern of grain size, which grades from fine grained in the basin center to coarse grained on the basin perimeter, generally is similar within both units of basin fill. Lower basin fill probably contains a consistently higher percentage of fine-grained material than does the upper basin fill. The relation between percentage of fine-grained material and hydraulic conductivity for the lower basin fill in the Tucson basin is shown in figure $9 G$. In the range of 20 to 60 percent, the hydraulic conductivity is less in the lower basin fill than for the same percentage of fine-grained material in the upper basin fill. The difference probably stems from differing degrees of cementation and from differences in the coarseness of the sand and gravel fraction of the material (Davidson, 1973, p. 29). If more than 60 percent of fine-grained material is present, differences in hydraulic conductivities in the two units are difficult to define. Hydraulic conductivity of the pre-Basin and Range sediments is variable and generally is about an order of magnitude lower than that in the overlying basin fill. No areal patterns are discernable on the basis of existing information.

\section{STREAM ALLUVIUM}

The occurrence of productive aquifers is correlative with the high-energy depositional environment. If saturated, the stream alluviums are the most productive aquifers in the basins because of their coarse-grained and unconsolidated nature. However, the stream alluvium is only locally saturated. In areas where consumptive use greatly exceeds recharge, the stream alluvium may be dewatered.

Stream alluvium along major drainages consists of unconsolidated silt, sand, gravel, and cobbles and where saturated has the greatest well yield of all units in the basin. Regionally, stream alluvium is a major aquifer along the Colorado, Gila, Salt, Santa Cruz, Verde, and San Pedro Rivers. The high hydraulic conductivity and specific yield make stream alluvium highly amenable to accepting, storing, and transmitting recharge from surface runoff. Small stream channels and washes that issue from the mountains contain fluvial deposits that allow rapid infiltration of runoff into the basin-fill sediments.

Along the lower Colorado River, hydraulic conductivity of the stream alluvium ranges from 200 to 400 $\mathrm{ft} / \mathrm{d}$ and locally may be nearly $1,000 \mathrm{ft} / \mathrm{d}$ (Metzger and others, 1973, p. 31). Metzger and others (1973, p. 31) reported specific capacities of more than 100 (gal/min)/ft of drawdown from wells that tap sufficient thicknesses of Colorado River gravels. Stream alluvium that underlies the Gila, Salt, Santa Cruz, 
and San Pedro Rivers is also highly permeable, although the saturated thickness generally is less than the stream alluvium along the Colorado River.

Specific yield of the stream alluvium in the Yuma area and Parker Valley, estimated from analyses of drillers' logs, averaged more than 18 percent and locally may be as much as 25 percent. Specific yield for stream alluvium in the San Pedro Valley derived from model calibration ranges from 13 to 15 percent (Freethey, 1982). Stream alluvium, because of its high hydraulic conductivity and specific yield, permits rapid infiltration of recharge to the underlying aquifer.

\section{WATER-RESOURCES DEVELOPMENT}

\section{HISTORY OF DEVELOPMENT}

From prehistoric times through the late 19th century, the base flow of streams was an important source of water in the study area. A number of streams, including almost the entire length of the Gila River, flowed perennially. Archeological evidence indicates that prehistoric people used surface waters for agricultural purposes. Remnants of major irrigation systems have been found in several areas, particularly in the Salt River Valley and along the Gila River.

Early settlers were attracted by perennial streamflow because they recognized the importance of water in the arid environment. The flat land of the flood plains, fertile soil, and lush vegetation were added attractions to settlement. Development of population centers and areas of intense water use adversely affected the hydrologic balance. The degree of development and the immediacy of the effect were variable from basin to basin, depending on the hydrologic setting.

In general, human activities affected the hydrologic setting of the region by altering the surfacerunoff characteristics. Trapping of beavers and woodcutting in the riparian zone probably had an impact on hydrology. Introduction of livestock by Spanish missionaries in the late 1600's and early 1700 's and importation of cattle in the 1870's also had some effects. The long-term effect was overgrazing followed by increased runoff and erosion. Severe headward erosion in most drainages was first documented in the latter part of the 19th century and continues today. Other developments resulted in much more dramatic responses. The construction of dams resulted in some reaches of perennial streams being completely dried up.
Early settlers began developing the water resources in the late 1800's. In 1867, an enterprising group of men formed a ditch company and diverted water from the Salt River near present-day Phoenix to irrigate a few acres of pasture. By 1875 , surface water of the Gila River was being diverted at several locations from Cliff, New Mexico, to Yuma, Arizona. In 1877, diversion of water from the Colorado River began near Blythe, California.

By 1889, the total irrigated acreage in Arizona was nearly 66,000 acres (Davis, 1897, p. 54). Because of the arid environment, any successful agricultural development depended on a reliable water supply; however, the lack of reservoirs for regulation of flow to sustain agriculture during drought periods resulted in a high variability of crop production and economic return. More than 132,000 acres were being irrigated in the Phoenix area when the Federal Reclamation Act of 1902 was passed. The act provided funds for construction of dams and reservoirs that would regulate surface water and provide water for irrigation. In 1911, Roosevelt Dam was completed on the Salt River about $60 \mathrm{mi}$ eastnortheast of Phoenix. Subsequently, additional dams were constructed on the Salt, Verde, Gila, and Agua Fria Rivers to supply water for irrigation. In 1945, the total available surface-water storage in these reservoirs was about 3.4 million acre-ft. Flow of the Colorado River has been regulated since 1936 by a series of reservoirs with a total storage capacity of more than 30 million acre-ft.

The combined base flow of the Gila, Salt, Verde, and San Pedro Rivers was almost fully appropriated by the early 1900's. Increased use of ground water was necessary to supply increasing water demands and sustain the extensive development that now exists in many areas.

The first wells were shallow hand-dug wells of large diameter. Well drilling was encouraged by the Arizona Territorial Legislature in the hopes that vast quantities of ground water could be found that would result in an agricultural boom. In 1875 the legislature offered a $\$ 3,000$ reward to the first person to drill a flowing artesian well. Thereafter, wells were drilled deeper than was really necessary until 1883, when the reward was claimed and paid.

In the late 1800 's and early 1900's, a few wells existed along the riparian zone of perennial streams. Centrifugal pumps were the only type available at that time, and pumping was limited by the lifting capacity of the pumps. By 1915, an estimated 123,000 acre-ft of ground water was pumped from wells, mainly in the Florence-Coolidge and Phoenix areas (U.S. Geological Survey, 1982). 
Several factors greatly affected the use and development of the ground-water resources. Development of the deep-well turbine pump in the 1930's increased the accessibility of ground water. Availability of cheap electric power aided in the growth of ground-water use. Increased demands for agricultural products during and after the 1930's resulted in vast increases in pumpage. During World War II, the most substantial increase was in the acreage of cotton being grown in support of the war effort.

Since World War II, the aquifer systems have been increasingly stressed to support agricultural activities. By analyses of available water-use data, the estimated pumpage in 1942 was about 1.7 million acre-ft (fig. 10) and was the beginning of a period of rapid growth. By 1952, the estimated pumpage liad more than doubled to 3.8 million acre-ft, and by 1962, pumpage was about 4.8 million acre-ft. During 1950-80, average pumpage was estimated to be 4.8 million acre-ft/yr. The large volume of pumpage is about 2 to more than 200 times greater than the recharge rate in individual basins.

\section{RESPONSE OF AQUIFER SYSTEMS TO GROUND-WATER DEVELOPMENT}

The effects of extensive development of ground water include depletion of streamflow, capture of natural discharge, and areally extensive water-level declines that result from removal of water from storage (described in greater detail in the later section entitled "Water-Resources Development and Effects on Hydrologic Systems"). Initial development of water resources resulted in depletion of streamflow not only because of surface-water diversions but also because the first pumping occurred along streams where water levels were shallow. The pumping removed water from surface flow by inducing additional infiltration. As development increased, water levels were lowered and hydraulic gradients were reversed in some places. Reversal of hydraulic gradients resulted in decreases in natural discharge, including ground-water underflow out of the basin, evapotranspiration, and ground-water discharge to streams.

By far the greatest response in the aquifers to ground-water development was the water-level declines in developed basins. Water-level declines, which ranged from less than $50 \mathrm{ft}$ to more than 450 $\mathrm{ft}$ (pl. 2), were greatest in major agricultural areas. The magnitude of the water-level declines varies from basin to basin and reflects the influences of the geohydrologic environment and the magnitude and duration of the development. In areas where surface water is abundant, such as along the Colorado River, water levels rose in places because of the recharge of excess applied irrigation water, which was derived from surface diversions rather than from groundwater pumping. In basins where no perennial surface flow occurs and recharge to the basin is small, ground-water pumping of almost any magnitude represents withdrawals of water from aquifer storage; thus water-level declines occur.

Problems associated with water-level declines include land subsidence, which is a result of aquifer compaction; decreasing aquifer productivity with increasing depth to water; and increasing pumping lifts. The inelastic compaction of aquifer fine-grained deposits not only results in land subsidence but also in a permanent loss of aquifer storage. The severity of this problem is a function of not only the magnitude of ground-water withdrawal in relation to the available resource but also the character of the aquifer material. Therefore, lithologic information on characteristics and extent of fine-grained facies within the basin-fill sediments is important because of their influence on land subsidence.

\section{REGIONAL WATER BUDGET}

The regional water budget of the basin aquifers accounts for inflows to and outflows from the basins, and changes in the volume of water stored in the aquifers. Before 1940, the basin aquifers, except the aquifer in Salt River Valley, were in hydrologic equilibrium-that is, the inflow was approximately equal to outflow on the basis of the long-term flow conditions. Effects on the basin aquifers before 1940 from change in climate and withdrawals of ground water by early settlers were assumed to be small and negligible.

Climatic changes, if any, probably would affect the entire study area but are not thought to be substantial. Smith (1981) and Smith and Stockton (1981) concluded on the basis of tree-ring data that mean runoff for 1900 to 1979 was the same as that for 1580 to 1979 and that only minor climatic variations occurred during the past 400 years. Tectonic events, such as the earthquake of 1887 in northern Mexico, affected the ground-water conditions for at least a short time in the southeastern part of the study area (DuBois and Smith, 1980). The rest of the area is thought to be tectonically inactive; therefore, effects of this type should be minor if they occur at all.

Activities of Spanish explorers and early settlers may have slightly affected the basin aquifers. Surface-water diversions and associated relocation of 
potential recharge might have some effects, but their magnitude was small. Overgrazing might alter the rainfall-runoff relations within a watershed and was thought to be linked to the arroyo cutting that was common throughout the region in the late 19th century (Hastings and Turner, 1965). Downcutting of stream bottoms may have drained the shallow aquifers.

Other activities such as the building of stock ponds, timber cutting, and wildfire control probably had little effect. Data are not available to document changes in aquifer storage because development before 1940 was limited. Changes in aquifer storage before 1940 are small in contrast to the extensive removal of water from storage associated with the ground-water development after 1940.

Since development, outflow (mostly pumpage) from individual basins has exceeded inflow by 2 to more than 200 times. The increased outflow is de- rived mainly from water in aquifer storage. Of the total of 184 million acre-ft of water pumped from the aquifers during 1915-80 (fig. 10), about 100 million acre-ft of water was removed from the aquifer storage. Part of the pumped water returns to the aquifer through percolation under irrigated fields and part of the water returns to the aquifer from infiltration of surface flow in streams and canals. In 1980, the estimated total ground-water pumpage in the study area was about 4.5 million acre-ft, of which about 2.5 million acre-ft was supplied by withdrawal from aquifer storage.

\section{SUMMARY OF FLOW COMPONENTS}

A water budget describes all components of inflow, outflow, and change in volume of water in aquifer storage; however, only the components that affect

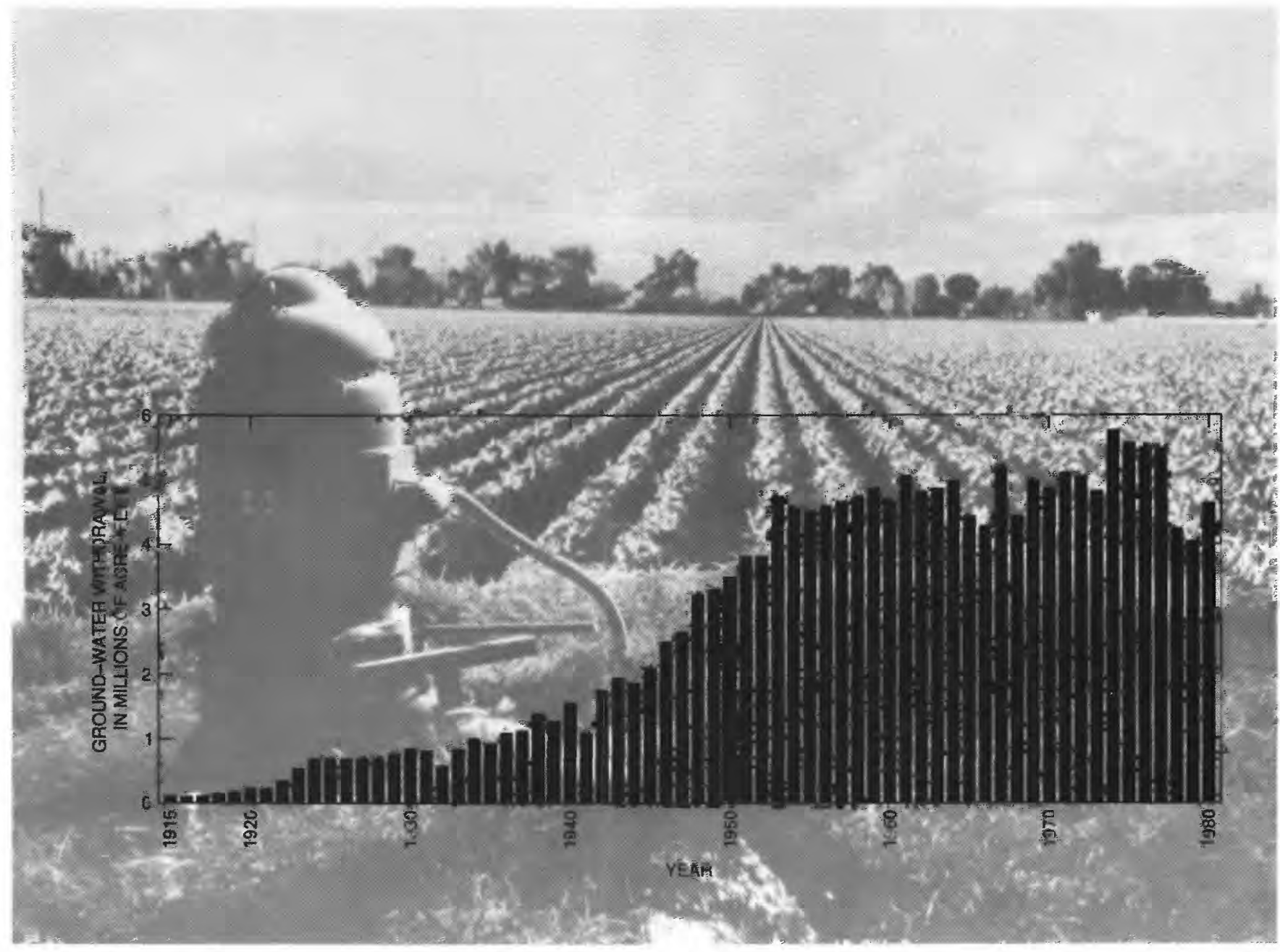

FIGURE 10.-Annual ground-water withdrawals, 1915-80. 
the basin aquifers are discussed here. Inflow components include ground-water underflow from adjacent basins and surface-water infiltration along the major streams of a basin and along mountain fronts (fig. 11). Outflow components include ground-water underflow leaving the basin, discharge to springs and streams, and evapotranspiration. An added outflow component is the consumptive use directly or indirectly related to human activities in a basin, such as agricultural irrigation, municipal, and industrial water uses. Two of the human activities in a basin are diversion of surface water and pumping of ground water, which, in turn, result in additional inflow such as seepage from canals and infiltration of excess irrigation water.

\section{INFLOW TO AQUIFERS}

Ground-water recharge to basin aquifers is from infiltration of surface water along the major drainage in the basins and at the mountain front and as underflow from upgradient, tributary basins. The magnitude of the individual components of inflow is dependent on the hydrologic setting of the individual basins.

Consolidated rocks of the mountains collect precipitation mainly as runoff to streams and washes that drain the mountains and provide recharge to the basins along the mountain fronts. Different types of consolidated rocks may influence the amount and mode of recharge. Wilson and others (1980, p. 4-24 and 4-25) stated that "Lowpermeability soils and bedrock give rise to high surface-runoff rates, and thus increase the potential of recharge to occur as streamflow infiltration along the mountain fronts. High-permeability soils and bedrock give rise to greater infiltration of precipitation in the mountains and thus increases the potential for recharge to occur as subsurface inflow into the regional aquifer."

Although the type of consolidated rock may influence the amount of recharge from the mountains, supporting information is lacking. Other factors, such as altitude and orientation of mountains, affect the amount of precipitation so that the effect of rock type on the amount of recharge would be difficult to determine. Available data indicate that the type of consolidated rock does not affect the chemical quality of ground water in the basins. Minerals within the basin-fill sediments are the primary control on the chemical quality of the ground water. Accumulation of chemical constituents in water that flows over consolidated-rock areas prior to recharging the basin aquifers is small compared to the rock-water reactions that take place in the basin-fill sediments.

Water also infiltrates to basin aquifers from surface-water bodies, such as streams, rivers, lakes, and canals. Because of low rainfall and large potential evaporation, the amount of water that reaches the basin aquifers directly from rainfall is limited. The areal distribution of recharge is controlled by the location of the mountain-front zone and the major surface-water bodies in the basins.

Mountain-front recharge occurs in a wide area at the mountain-basin interface and extends basinward for an unknown distance. The extent of the mountain-front recharge area is probably a function of the amount of water available for recharge and the hydrogeological characteristics of the soils and rocks. Mountain-front recharge generally occurs in areas that are underlain with coarse sediments and alluvial-fan deposits eroded from the adjacent mountains. These sediments provide a permeable path for water to enter the unsaturated zone and eventually move downward to the water table.

The other areas where a significant amount of water recharges the basin aquifers are along the major surface-water drainages in the basins. The stream course, whether it contains perennial or ephemeral flow, is incised in stream alluvium that may range from a few feet to as much as $300 \mathrm{ft}$ in thickness and from several hundred feet to more than $10,000 \mathrm{ft}$ in width. The stream alluvium generally is coarse grained, unconsolidated, rounded, and well sorted and allows rapid infiltration and a large storage of infiltrated water.

Underflow recharging a basin aquifer originates as infiltrated surface water in upgradient basins. This recharge differs from the recharge that originates from infiltration along major surface-water drainages within the basin because this recharge integrates the subsurface outflow from the upgradient basin. A time lag occurs between the time that water infiltrates the upgradient basin and when it enters the downgradient basin. The upgradient basins attenuate the amplitude of temporal variations in recharge so that the long-term recharge to the downgradient basin as underflow is virtually constant.

The total average annual recharge to the basin aquifers before development (about 1940) is estimated to be about 2.5 million acre-ft on the basis of the summation of recharge to individual basins in the study area. Recharge to individual basins was considered as the sum of mountain-front recharge, stream infiltration, and underflow-these components being adjusted to balance the estimated or 

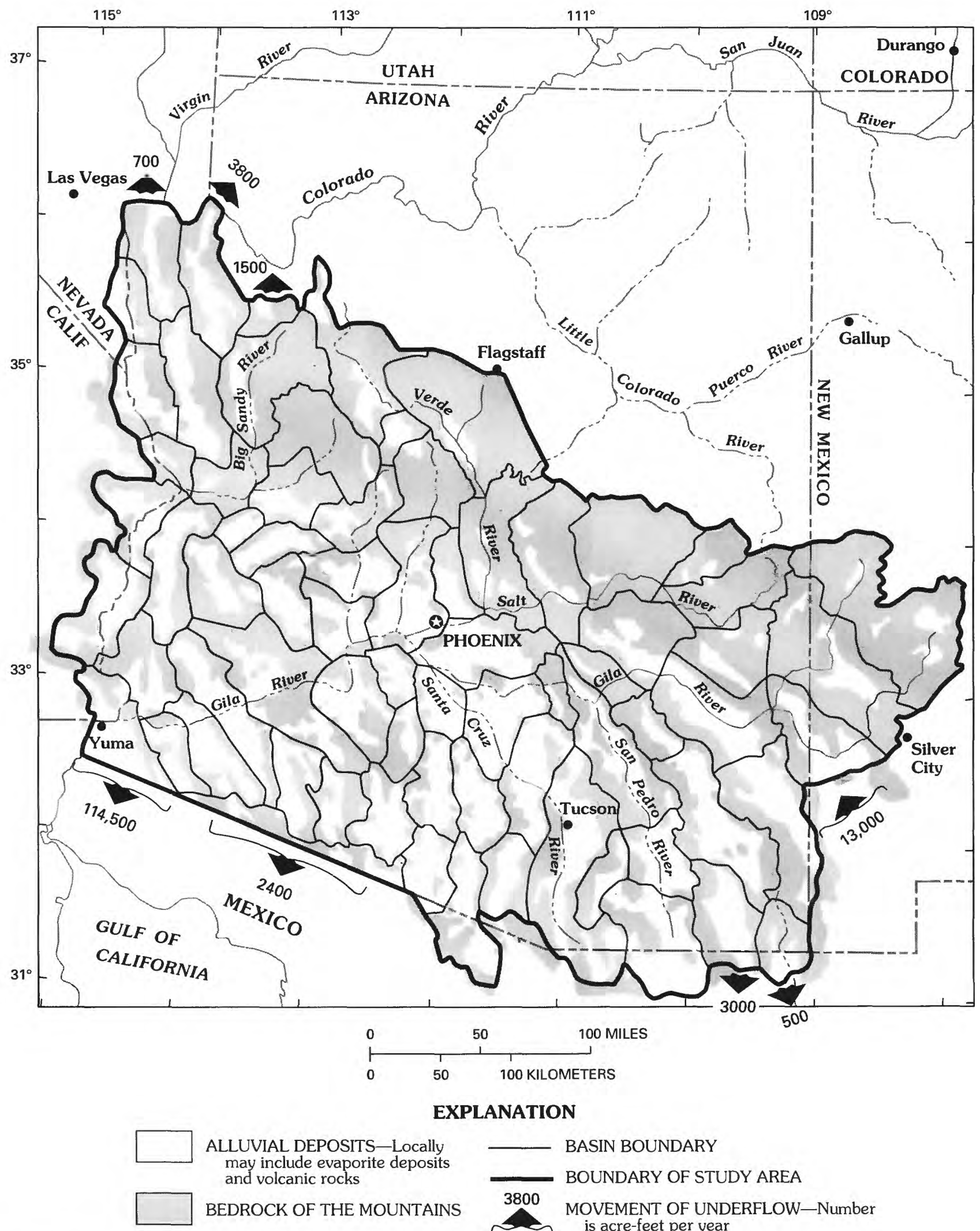

ALLUVIAL DEPOSITS-Locally may include evaporite deposits and volcanic rocks

BEDROCK OF THE MOUNTAINS

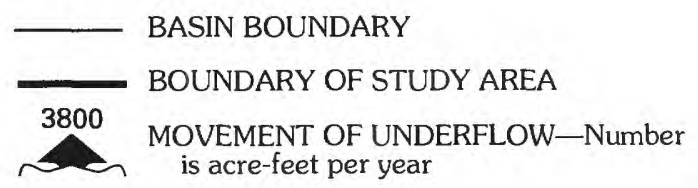

Figure 11.-Typical inflow and outflow components for predevelopment conditions in basins of the study area. 
measured discharge as described in Freethey and Anderson (1986). Total recharge to all basins includes about one-third as mountain-front recharge and two-thirds as infiltration along the surface-water drainages. A large part of the stream infiltration occurs along the Colorado River. Less than 1 percent of the estimated total recharge is underflow through the boundary of the study area (fig. 12). Most of the north-to-northeast boundary of the study area is assumed to approximate the ground-water divide between the Basin and Range lowlands and the Plateau uplands provinces; therefore, no underflow is assumed.

As a result of development in the study area, changes in the annual recharge rate occurred on!y in the component of infiltration along formerly perennial streams. Pumping near streams induces additional infiltration.

Changes in recharge can best be illustrated by examining the average annual flow of the Gila River near Dome, Arizona. This site is about $10 \mathrm{mi}$ upstream from the mouth of the Gila River near Yuma; the total surface runoff from the Gila River drainage is monitored at this point. During 190340 , the average annual flow past that point was 620,000 acre-ft/yr (U.S. Geological Survey, 1954); the average annual flow for 1941-78 was less than 22,000 acre-ft/yr (U.S. Geological Survey, issued annually). Assuming that no long-term changes in the precipitation and runoff patterns occurred in the drainage area, this reduction in streamflow indicates an increase in water usage of nearly 600,000 acre- $\mathrm{ft} / \mathrm{yr}$. This increase in water use probably represents an increase in recharge along the formerly perennial streams and the effects of surface storage. Changes in recharge along the Colorado River, if any, are difficult to define because of the large magnitude of flow in the river.

\section{AQUIFER STORAGE AND MOVEMENT OF GROUND WATER}

The amount of water stored in the voids of the basin-fill sediments is large. The water was accumulated over thousands of years. The volume of water stored in aquifer sediments greatly exceeds annual inflow and outflow. Freethey and Anderson (1986) estimated that about 900 million acre-ft of recoverable water was stored in the upper $1,200 \mathrm{ft}$ of the basin-fill sediments prior to ground-water development. This amount of water represents about five times the total volume of water that has been pumped from the basin aquifers during 1915-80 and is nearly 400 times the estimated annual rate of ground-water depletion. Although the estimated volume of water is in storage and recoverable, it is distributed throughout the study area, and in places the chemical quality of the water may not be suitable for all uses.

Rate of movement of water through a basin is a function of the hydraulic characteristics of the aquifer. The preponderance of the flow probably occurs within the upper 1,000 to $2,000 \mathrm{ft}$ of saturated basin sediments because the deeper sediments generally are more dense and more cemented. Before development, the direction of ground-water flow was generally parallel to the direction of the surface-drainage system. The only exception might be in the low-relief topographic areas where the ground-water divide did not coincide with the surface-water divide. Flow occurred from the perimeter of the basins toward the basin axis, then flowed downvalley toward the outflow point, which typically is a constriction formed by a narrowing and thinning of the basin sediments between mountain masses.

\section{OUTFLOW FROM AQUIFERS}

Before development, water outflow from the basin aquifers occurred as flow to the surfacedrainage system, such as springs or base flow in streams, as evaporation and transpiration from soil and vegetation, or as underflow out of the basin. The relative magnitude of each outflow component in a particular basin depends on the hydrologic setting, which cannot be readily quantified during the study without additional geohydrologic information. One or all of these components may have occurred in a basin. Large-scale pumping is another major outflow component added to the natural outflow components since ground-water development began.

Discharge of ground water to streams and springs indicates that the water table in the discharge areas intersects the land surface, which indicates that the combined hydraulic conductivity and cross-sectional area at the outflow point along the basin boundary is insufficient to transmit all of the downvalley flow. The controlling factors on this downvalley flow are hydraulic conductivity of the sediments, the cross-sectional area of the basin where underflow occurs, and the hydraulic gradient between the upgradient and downgradient basin. Typically, some part of the cross section of the aquifer outflow is underlain by flood-plain alluvium that has a high hydraulic conductivity. If the 


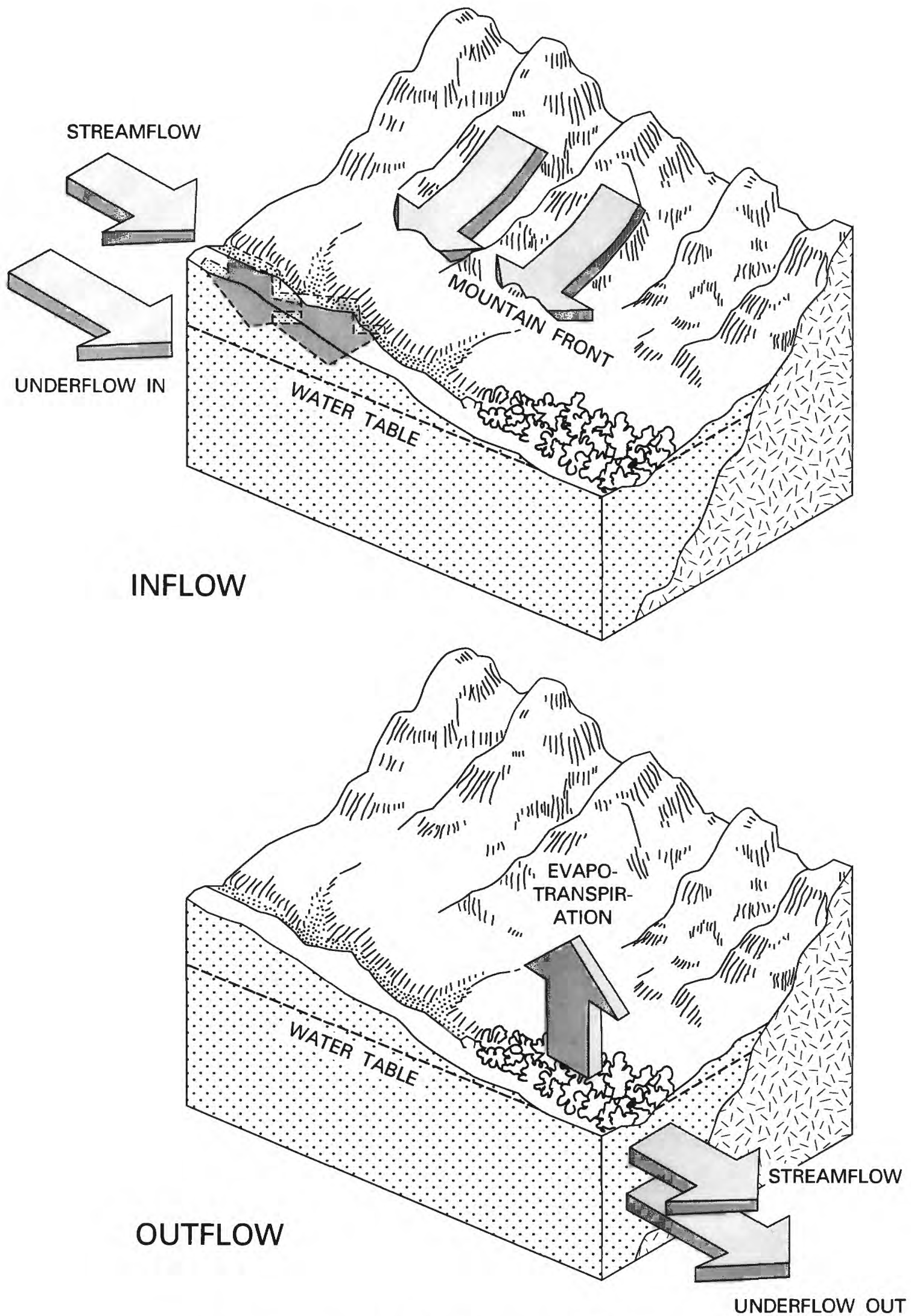

Figure 12.-Ground-water underflow into and out of the study area. 
outflow area is large enough or the flow quantity is small, the water table near the outflow area may be deep and phreatophytes may not be present.

The presence of phreatophytes and riparian vegetation, such as mesquite and cottonwood, indicates the availability of shallow ground water. Consumptive use by riparian vegetation was a significant ground-water discharge in many basins before major development occurred. Information on size, density, and areal extent of phreatophytes can be used as an aid in the definition of the local hydrologic setting.

Development within a basin affects the quantity of natural discharge. Ground-water pumpage is a major discharge in many developed basins. As pumpage increases, natural discharge tends to decrease. The decrease in natural discharge is termed "capture" (Lohman and others, 1972, p. 3). Perennial streamflow has been depleted in many places as a result of ground-water withdrawals and construction of surface-water storage reservoirs in the upstream areas. Decrease in evapotranspiration by phreatophytes is closely associated with the decrease in streamflow and lowering of water levels. The eradication of phreatophytes may also reduce evapotranspiration in some places.

\section{REGIONAL PATTERNS OF FLOW COMPONENTS}

The generalized hydrologic conditions before development were discussed by Freethey and Anderson (1986). The general ground-water flow direction, shown on plate 3 , was markedly similar to the pattern of the surface runoff. Differences in magnitude of flow exist among basins as a result of differences in basin physiography and hydrology. The reaction of the basin aquifers to development also depends at least in part on the magnitude of the components of inflow and outflow.

Data for estimating inflow and outflow components for individual basins are sparse. Precipitation and streamflow data were compiled and used as a starting point in analyzing the water budgets. Evapotranspiration was estimated on the basis of 1935 rerial photography to map riparian vegetation and an estimated value of consumptive use for the particular vegetation type.

\section{GROUND-WATER UNDERFLOW}

Underflow from outside the study area into the basin aquifers is small. A large part of the north boundary of the study area is assumed to coincide with a ground-water divide; therefore, no underflow moves across the boundary. Underflow to the basin aquifers occurs only along a small reach of the southeast boundary where ground water in a contiguous alluvial basin in New Mexico flows toward the study area (fig. 12). The underflow from the New Mexico basin was estimated to be about 13,000 acre-ft/yr (O'Brien and Stone, 1983; Freethey and Anderson, 1986). Ground-water development has been insignificant in the underflow area; therefore, no change in the underflow estimate is assumed.

Underflow out of the study area occurs mainly along the southern part of the study boundary across the international boundary between Mexico and the United States (fig. 12). A minor amount of discharge occurs from the basins in the northwest where ground water discharges to the Colorado River. Total underflow was estimated to be about 130,000 acre-ft/yr on the basis of hydraulic gradient, hydraulic conductivity, and estimated basin-fill thickness near the study boundary. Ground-water development in the study area may reduce outflow from the Yuma and Douglas basins; however, the exact amount cannot be estimated without additional information.

Ground-water underflow between individual basins within the study area ranges from a few hundred to several thousand acre-feet per year. The flow pattern closely parallels the surface-water drainage pattern; however, the quantity of underflow does not always increase in the downstream direction. The factors that control the quantity of underflow are the quantity of recharge and the consumptive use within the upgradient basins. Three factors that influence whether the discharge occurs as surface or subsurface flow are cross-sectional area of the alluvial interconnection between basins, the hydraulic conductivity of the alluvial deposits, and the hydraulic gradient of ground water between the basins. In many basins the underflow is minimal because of limited cross-sectional area between basins. In these areas, ground water dominantly discharges through springs to streams and as evapotranspiration. Estimates of underflow from individual basins range from zero to about 30,000 acre-ft/yr (Freethey and Anderson, 1986).

The effects of ground-water development on underflow between basins ranges from no effect to an almost complete capture of the underflow. In major developed basins, where significant depletion of storage and water-level declines have occurred, a decrease in the underflow into the next downstream basin has resulted. 


\section{MOUNTAIN-FRONT RECHARGE}

Mountain-front recharge is water that infiltrates into the zone of coarse alluvium that extends several miles basinward from the mountain-basin interface. Water flows downward through the unsaturated zone in a broad band paralleling the mountain front. The width of the recharge zone is dependent on the nature and magnitude of the runoff from the consolidated-rock areas. Infiltration takes place in the coarse-grained, unconsolidated sediments. Subsequent movement of water through the unsaturated zone is controlled by the unsaturated hydraulic conductivity, which varies with the physical nature and the moisture content of the sediments. The thickness of the unsaturated zone in the recharge areas typically is in the range of 200 to $700 \mathrm{ft}$. The water is assumed to enter the basin aquifer at a nearly uniform flow rate owing to the damping effects in the unsaturated zone. Some perched water may occur on hardrock pediments near the mountains or overlying low permeability fine-grained sediments in the recharge zone.

The quantity of water potentially available for recharge is approximately equal to the precipitation minus evapotranspiration on the watershed. Part of the precipitation accounts for changes in soil moisture, which are assumed to be small over a long period. Part of the precipitation leaves the basin as surface runoff, at least during periods of greater than average rainfall. Mountain-front recharge was assumed to have an areal distribution that is a function of the average annual precipitation in the adjacent mountain areas. Average annual precipitation is related to altitude. Mountain-front recharge, therefore, is expected to be greater in those basins surrounded by the higher mountain ranges.

In spite of the differences in geology, topography, vegetation, and surface-runoff characteristics, a regression equation was established between the average mountain-front recharge $\left(Q_{\text {rech }}\right)$ and the total annual volume of precipitation on the watershed when the precipitation $(P)$ is in excess of $8 \mathrm{in} . / \mathrm{yr}$ $(P>8)$. The equation was initially based on available previous estimates of recharge in a few basins (Anderson, 1972; Freethey, 1982; Halpenny and others, 1952). By using this equation, the average annual mountain-front recharge to each basin in the study area was estimated. These estimates were then used in the water budgets of the individual basins. Adjustments were made to balance the water budgets of the individual basins and the water budget of the entire study area. After an iterative process of balancing and modifying, the resulting mountain-front recharge estimates were of similar magnitude and, although there were a few exceptions, appeared reasonable for basins with similar physiography and hydrology. The final equation used to estimate the mountain-front recharge from precipitation is

$$
\log Q_{\text {rech }}=-1.40+0.98 \log P \text {, where } P>8 \text {. }
$$

The equation represents a means of approximating the total annual volume of mountain-front recharge to an entire basin. The process of developing a general equation with which to estimate the average annual mountain-front recharge to each basin was somewhat circuitous and may be biased because of the limited areas where data are available. The equation is calibrated only by the fact that the individual basin water budgets and the regional water budget are in balance. The reliability of the recharge estimates, therefore, is dependent on the reliability of estimates of other budget components.

Precipitation data are readily available throughout the area. The distribution of the average annual precipitation shown in figure $2 A$ was used to obtain the total volume of precipitation that is greater than $8 \mathrm{in} . / \mathrm{yr}$. The regression equation is calibrated on the basis of recharge values from 12 numerical models (Robertson, 1991) and previous estimates of recharge in a few basins; however, the equation needs further testing. The regression equation should not be applied to small watersheds and should not be used for isolated areas. The equation is also not adjusted for variations in geology, vegetation, and other factors.

The use of the annual volume of precipitation that is greater than 8 in./yr on the entire watershed yielded better estimates of mountain-front recharge than using the total volume of precipitation (figs. $13 A, B)$. The correlation index $(R)$ for the regression is 0.95 using precipitation rates greater than $8 \mathrm{in} . / \mathrm{yr}$ and is 0.85 using the total precipitation. The threshold value below which little or no recharge may occur was set arbitrarily at the precipitation of $8 \mathrm{in} . / \mathrm{yr}$. Use of this threshold value effectively subtracts the amount of precipitation that is lost to soilmoisture deficits and evapotranspiration.

If the water budget of a basin is small, then values associated with each flow component are also small. The estimates of various flow components can be greatly influenced by the degree of uncertainties of the flow component. For example, the 95-percent confidence interval of the regression equation diverges rapidly when the mountain-front recharge is less than 1,000 acre-ft/yr (fig. 14). This is due to lack of data and uncertainties associated with a small 
water-budget component and low precipitation volumes. Attempts to refine the low end of the graph may not be justified.

Mountain-front recharge is independent of development in a basin. The only factor that could affect the quantity of mountain-front recharge is surficial alterations in the mountain areas that would result in a change in runoff. Climatic cycles may also affect this recharge. The regression equation does not include such factors as geology, land slope, vegetation, and soil type that may need to be considered for any future refinement of the equation.

\section{STREAMFLOW INFILTRATION}

Ground-water recharge occurs through infiltration of surface water in parts of the basins. In the most arid western basins, some recharge probably originates as infiltration along the main stream that drains the basin. The amount, in terms of total annual recharge to the basin, is unknown but probably is highly variable because of large variations in runoff from year to year. During many years, no flow occurs in the main streams of the most arid western basins. The other extreme occurs in basins transected by perennial streams where the aquifer is dominated by surface-water infiltration.

Recharge from infiltration of surface water along major streams is related to the magnitude and duration of surface flow. Availability of near-surface pore space within which to store and transmit water is critical. In stream reaches that contain perennial flow, the amount of water stored and transmitted through the aquifer is maintained at the maximum level possible for the prevailing hydrologic conditions. Additional surface flow can infiltrate and recharge the aquifer only if some of the ground water is withdrawn.

Stream infiltration was a substantial part of the water budget before development in basins that are crossed by the Colorado, Gila, Salt, Verde, Santa Cruz, San Pedro, and Bill Williams Rivers (fig. 14). These rivers were both gaining and losing streams depending on location along the river and time of year. Before development and initiation of surface-flow depletion, the river stages functioned as major controls on the heads in the alluvial aquifers. The construction of
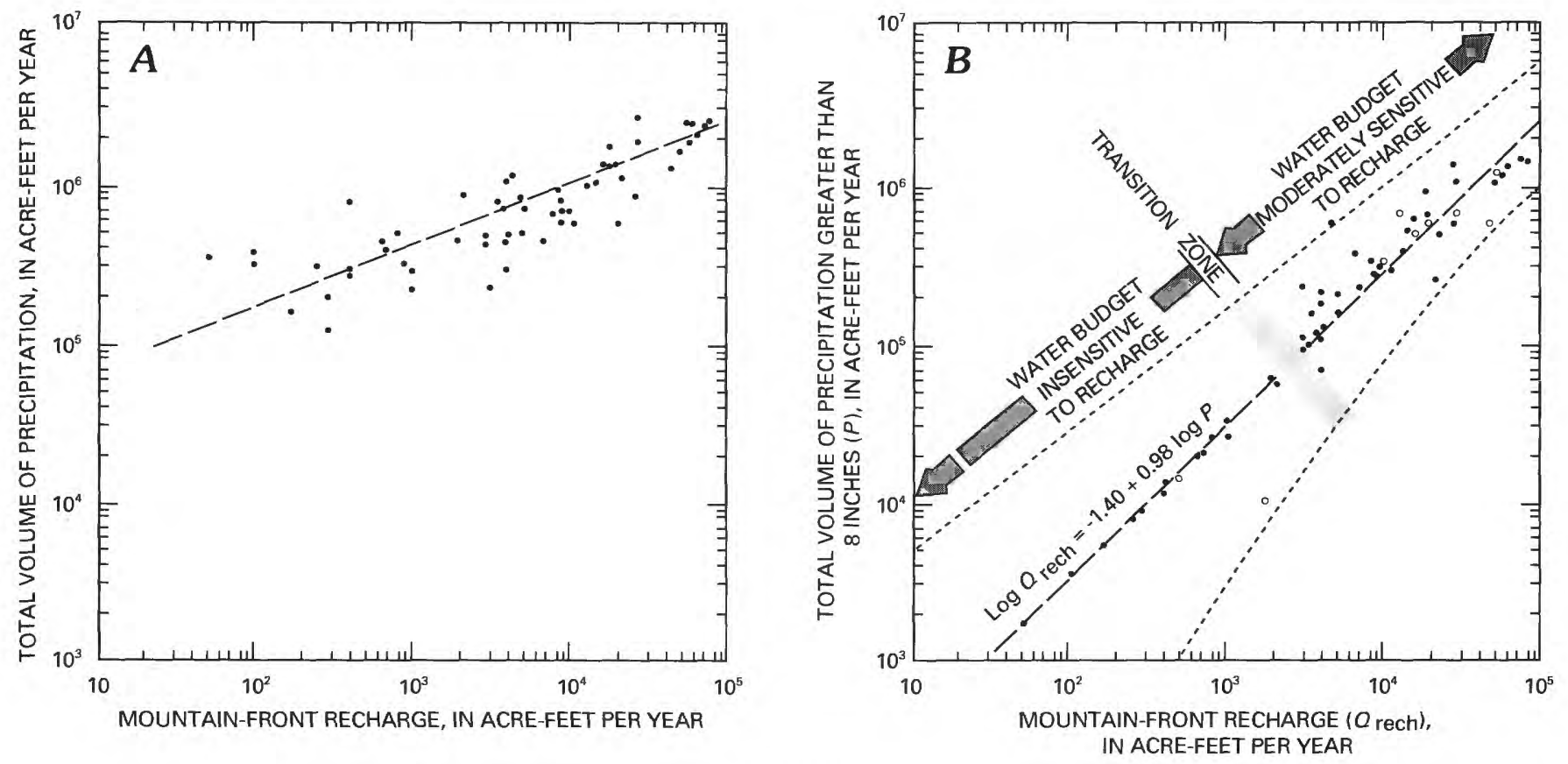

EXPLANATION

- MOUNTAIN-FRONT RECHARGE VALUE USED IN NUMERICAL MODEL OF BASIN - Shown only in B

- MOUNTAIN-FRONT RECHARGE VALUE USED IN REGIONAL WATER BUDGET

Figure 13.-Relation of estimated mountain-front recharge to total volume of precipitation. $A$, Total precipitation on basin. $B$, Total precipitation greater than 8 inches. 


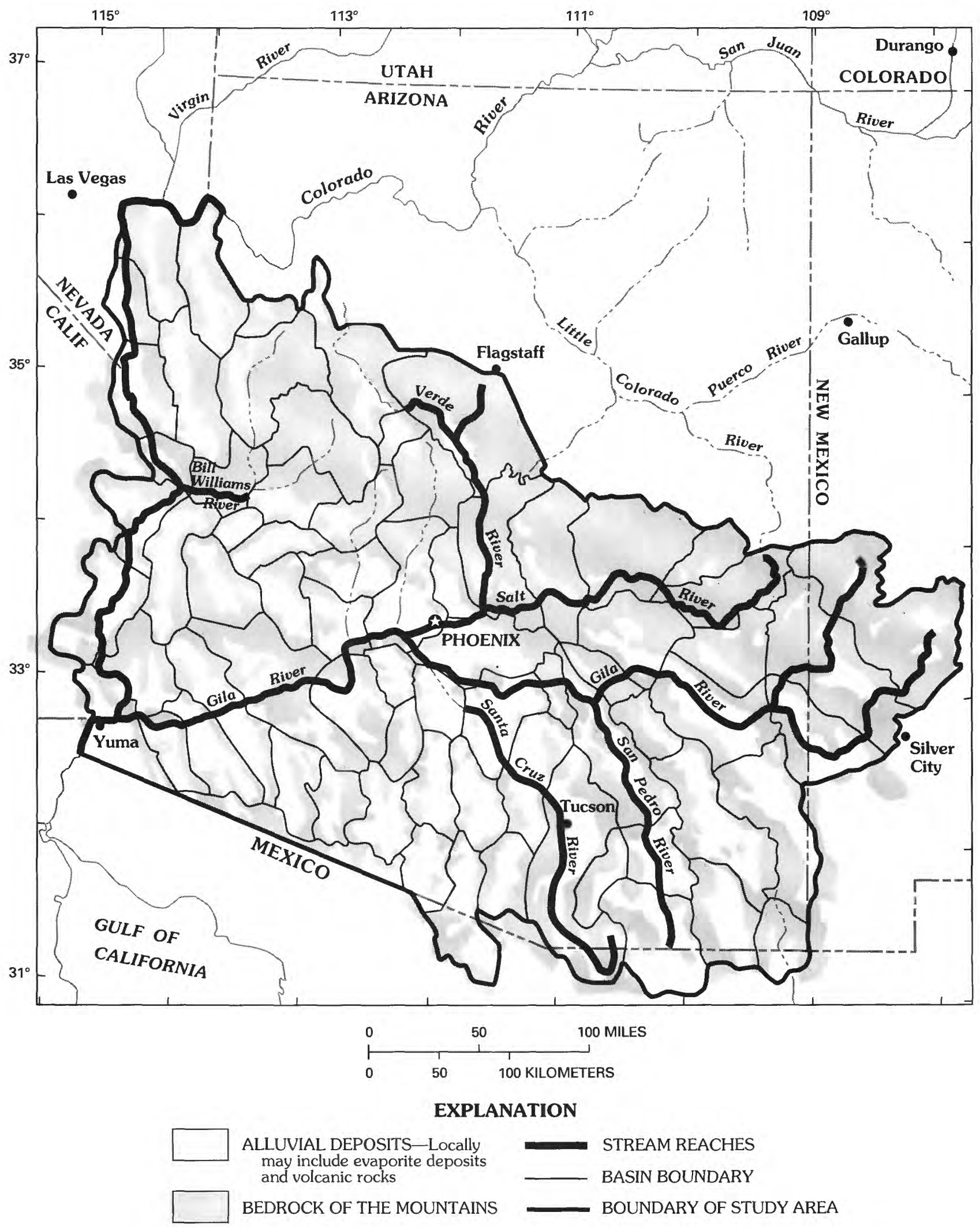

Figure 14.- Stream reaches in which infiltration was a significant part of the predevelopment water budget. 
reservoirs for storage and regulation of surface water and the extensive development of ground water greatly altered this condition along several streams. As ground-water levels declined, a condition which could be beneficial by inducing more stream infiltration and reducing evapotranspiration, a larger volume of alluvial deposits became available to store infiltration from intermittent flow events. Changes in the pattern of infiltration occurred in varying degrees along reaches of the Gila, Salt, San Pedro, Santa Cruz, and Verde Rivers.

\section{EVAPOTRANSPIRATION}

In many basins, evapotranspiration was the principal ground-water discharge before development. Evapotranspiration occurs extensively in areas of perennial streamflow and (or) shallow ground water. The quantity of consumptive use through evapotranspiration is primarily a function of depth to water, vegetation type, and characteristics of soils (Robinson, 1958). Depending on the hydrologic setting of an individual basin, the occurrence of evapotranspiration could be limited to the extreme downstream area of the basins-at the outlet-or occur throughout the entire reach of the main streams.

The area of greatest evapotranspiration is along the perennial streams. The Colorado and Gila Rivers are the two largest perennial streams (fig. 14). Mesquite and associated riparian vegetation are abundant along these streams, and ground water occurs at shallow depth throughout extensive flood-plain areas. Basins along the Colorado River continue to have evapotranspiration as the largest component of ground-water discharge. Along the Colorado River, the total predevelopment consumptive use by evapotranspiration was estimated to have been about 1.3 million acre- $\mathrm{ft} / \mathrm{yr}$ on the basis of identification of vegetation from aerial photographs taken in the 1930's. Along the Gila River and its tributaries, consumptive use by evapotranspiration before ground-water development was estimated to be about 800,000 acre$\mathrm{ft} / \mathrm{yr}$. The long-term effect of development has decreased the annual evapotranspiration by native vegetation. Along the Colorado River, a large part of the native riparian vegetation has been replaced by agricultural crops. In the Gila River drainage basin, the increased depths to water have resulted in a small reduction in consumptive use by riparian vegetation. Estimates of the present total discharge through evapotranspiration by native vegetation along the Gila River are not available but probably remain a large percentage of the original estimate.
The estimated water budget before development of ground water in the study area is summarized in table 2.

\section{EFFECTS OF DEVELOPMENT ON BASIN WATER BUDGETS}

Development resulted in changes of selected flow components-particularly outflow components. Ground-water pumpage was the major increase in ground-water discharge and resulted in an imbalance of the inflow-outflow equation. During the 1970 's, annual ground-water withdrawals averaged about 4.5 million acre-ft (fig. 10), which is nearly double the estimated total predevelopment outflow from the basins (table 2). More than one-half of this pumpage was derived from storage within the individual basins.

Discharge of ground water to streams and as evapotranspiration decreased in most of the developing basins. In the extreme cases, stream reaches that formerly contained perennial flow now are dry except for periods following severe precipitation events. Also, some areas that formerly were covered by riparian vegetation are now barren because of the lowering of water levels below the root zone of the vegetation. Some inflow which represents additional recharge that has accompanied development include infiltration of sewage effluent, canal seepage, and recharge from excess applied irrigation water (Anderson, 1983). Estimates of recharge from seepage and excess applied irrigation water have been made for individual areas. Sewage effluent is a substantial source of inflow in a reach of the Santa Cruz River downstream from the sewage treatment plants in Tucson and in reaches of the Salt and Gila Rivers downstream from the sewage treatment plants in Phoenix. Other areas also receive inflow from the release of sewage effluent to stream channels.

\section{GROUND-WATER FLOW PATTERNS}

\section{AREAL PATTERN OF HYDRAULIC HEADS}

Differences in areal patterns of hydraulic heads exist and are directly related to ground-water flow within the basin. Two extreme conditions that exist in the study area can be shown by the predevelopment head distribution of the upper San Pedro Valley and Harquahala Plain. In upper San Pedro Valley, the generalized water-level contours are Vshaped; the apex of the "V" is located near the San 
TABLE 2.-Estimates of water budget before development (about 1940), in acre-feet per year ${ }^{1}$

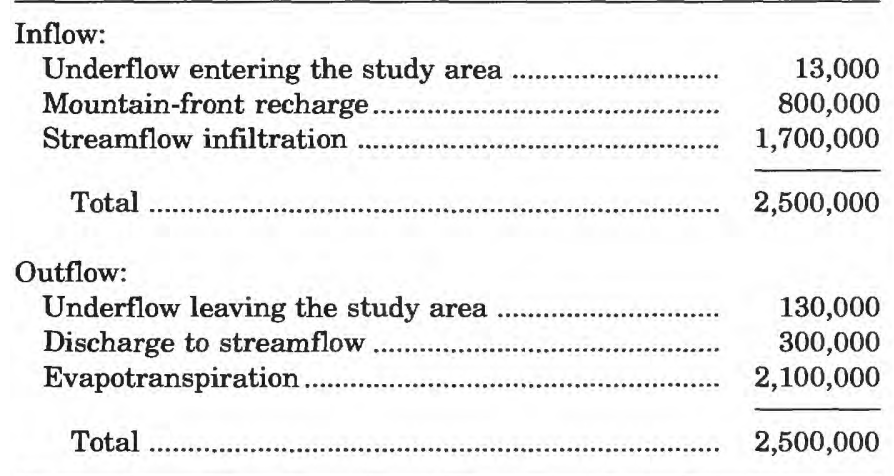

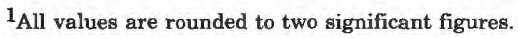

Pedro River, which is near the center of the basin (fig. 15). In contrast, in Harquahala Plain, the generalized water-level contours are almost straight lines extending across the basin normal to the direction of the main surface-water drainage. Between these two extremes are basins that have U-shaped contours (fig. 16).

The V-shaped contour is an indication of substantial basin perimeter recharge and a high rate of ground-water discharge along a stream near the center of the valley. For example, in the upper San Pedro Valley (fig. 15A), mountain-front recharge is large compared to other inflow components and the water-level contours are nearly parallel to the mountain fronts. The central drainage (the San Pedro River) represents an almost continuous linear discharge. The San Pedro River is a gaining stream in places, and ground-water discharge occurs throughout the flood-plain area through transpiration by riparian vegetation and evaporation from surface water and soils where water level is shallow. The distance that ground water flows in this type of basin is short.

In contrast, the generalized head distribution in the Harquahala Plain (fig. $15 B$ ) is a series of parallel contour lines normal to the axis of the basin. Water enters the basin mainly at the upstream end, and if mountain-front recharge occurs, it is minimal. Generally, data are inadequate to define any small curvature in the hydraulic head contours near the basin boundary. Discharge is only at the downstream end of the basin. Long flow paths characterize groundwater flow in this type of basin.

The generalized U-shaped contours of head distribution indicate various combinations of groundwater recharge and discharge. The water-level con- tours for the Tucson basin illustrate a composite flow condition in which multiple sources of inflow and outflow exist (fig. 16). The shape of the water-level contours indicates that mountain-front recharge occurs along the basin perimeter and underflow occurs at the upstream end. Surface-water infiltration represents an additional inflow source.

Head distribution may be used to infer certain characteristics of flow in a basin. For example, areas of mountain-front recharge generally can be delineated. The quantity and distribution of recharge may also be estimated using flow-net analysis with a known water-level configuration.

Where streamflow infiltration is a large source of recharge, head distribution can be affected. In the study area, however, the effect of streamflow infiltration on the water-level contours generally is not apparent because data are insufficient to document small head differences in the water table and to define small water-level changes over large areas.

\section{VERTICAL MOVEMENT OF GROUND WATER}

Most ground-water flow is assumed to occur in the upper 1,000 to $2,000 \mathrm{ft}$ of the basin-fill sediments. Several basins, however, are as much as $10,000 \mathrm{ft}$ or more in depth. The ability of the deeplying deposits to transmit water is related to composition, cementation, and degree of consolidation of the overlying materials. Wells penetrate only the upper 1,500 to $2,000 \mathrm{ft}$ in most basins because of economic and practical constraints. A sufficient supply of water generally can be developed within this depth, and deeper drilling is not necessary. Well yields generally decrease with depth; analogously, the flow through the basin aquifer probably decreases with depth. Because of the general concept of deposition of extensive fine-grained sediments at depth in a closed-basin environment, hydraulic conductivity of these fine-grained sediments is assumed to be small. Other contributing factors are the greater degree of consolidation of the deeper sediments because of greater overburden pressures. Storage of water within and movement of water through the deep-lying sediments probably are substantially lower than those of the uppermost sediments.

Vertical variations in head at a single location are documented for several basins. The measured heads increase and decrease as a function of increasing depth. Davidson (1973) attributed the vertical-head differences in the Tucson basin to the presence of clay and silt lenses. Known vertical head differences 
in the basins range from about 5 to $20 \mathrm{ft}$. A general trend cannot be documented at the present time; however, the variations probably are related to the heterogeneous character of the basin deposits. The head in most wells probably represents a composite for the various fine- and coarse-grained stringers and lenses penetrated by the well.

\section{REGIONAL GEOHYDROLOGIC CATEGORIZATION}

The initial procedure for categorizing the 72 basins in the study area was restricted to using observable surface characteristics. This procedure functioned only as a guide to develop representative conceptual models of the hydrologic conditions in the basins. The purpose of the categorization was to formulate, apply, and evaluate information that can be transferred among the basins within a group.

As part of the concept of information transfer, similarities in ground-water inflow and outflow and subsurface lithology were used in the basin categorization, which were based on two geohydrologic factors-(1) estimated total downvalley flow, and (2) lithology of the basin aquifers. Both factors influence the response of a basin aquifer to development
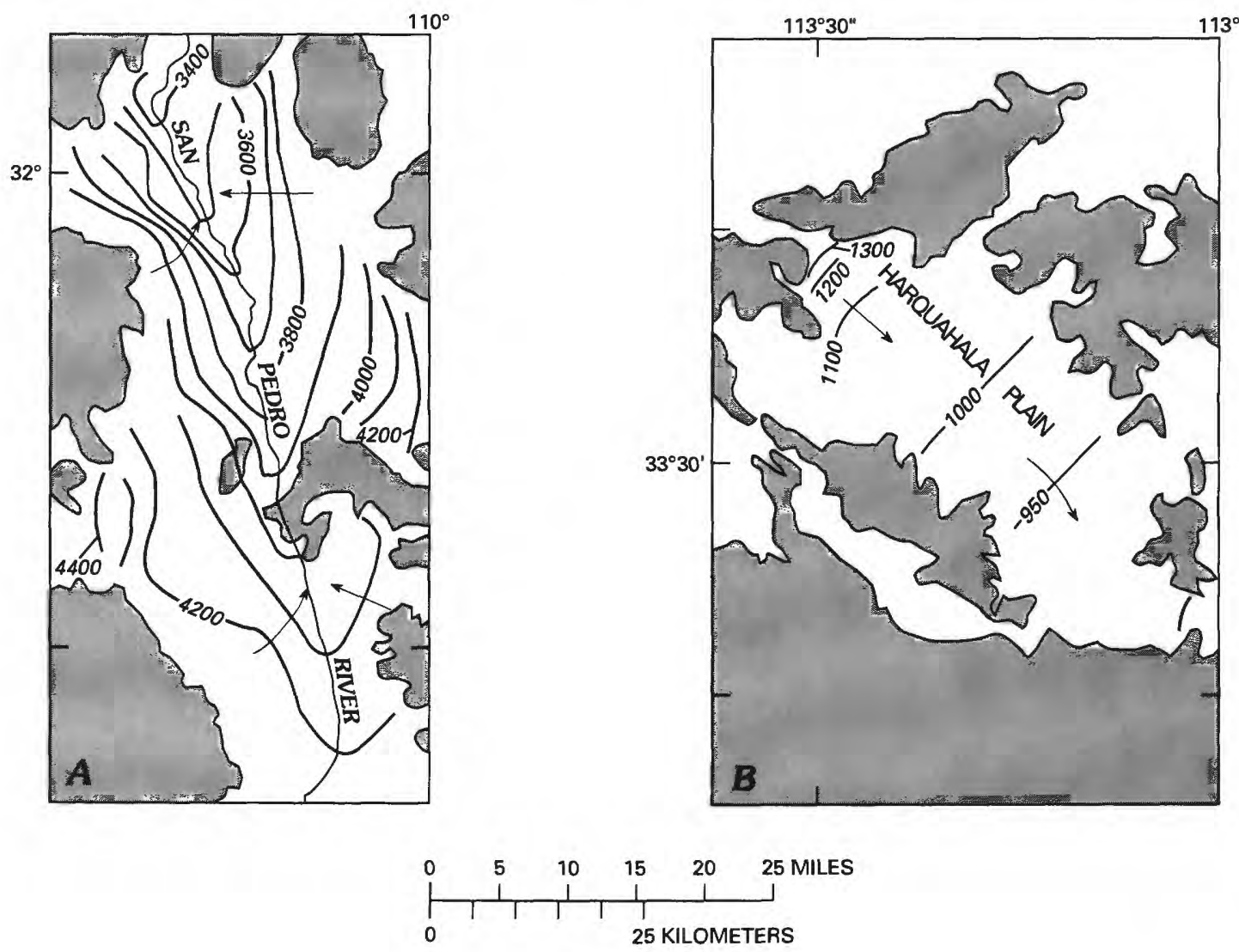

EXPLANATION

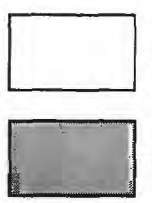

ALLUVIAL DEPOSITS

BEDROCK OF THE MOUNTAINS

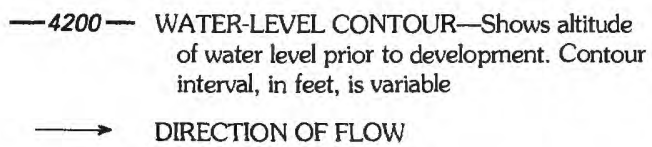

Figure 15.-Extremes in shape of water-level contours in basins of the study area. A, Upper San Pedro Valley. B, Harquahala Plain. 
stresses. On the basis of the two geohydrologic factors, the basins are divided into five groups-(1) southeast, (2) central, (3) west, (4) Colorado River, and (5) highland basins (fig. 17).

The quantity of downvalley flow (ground water and stream base flow) was divided by the areal extent of basin fill in each basin to develop the value of

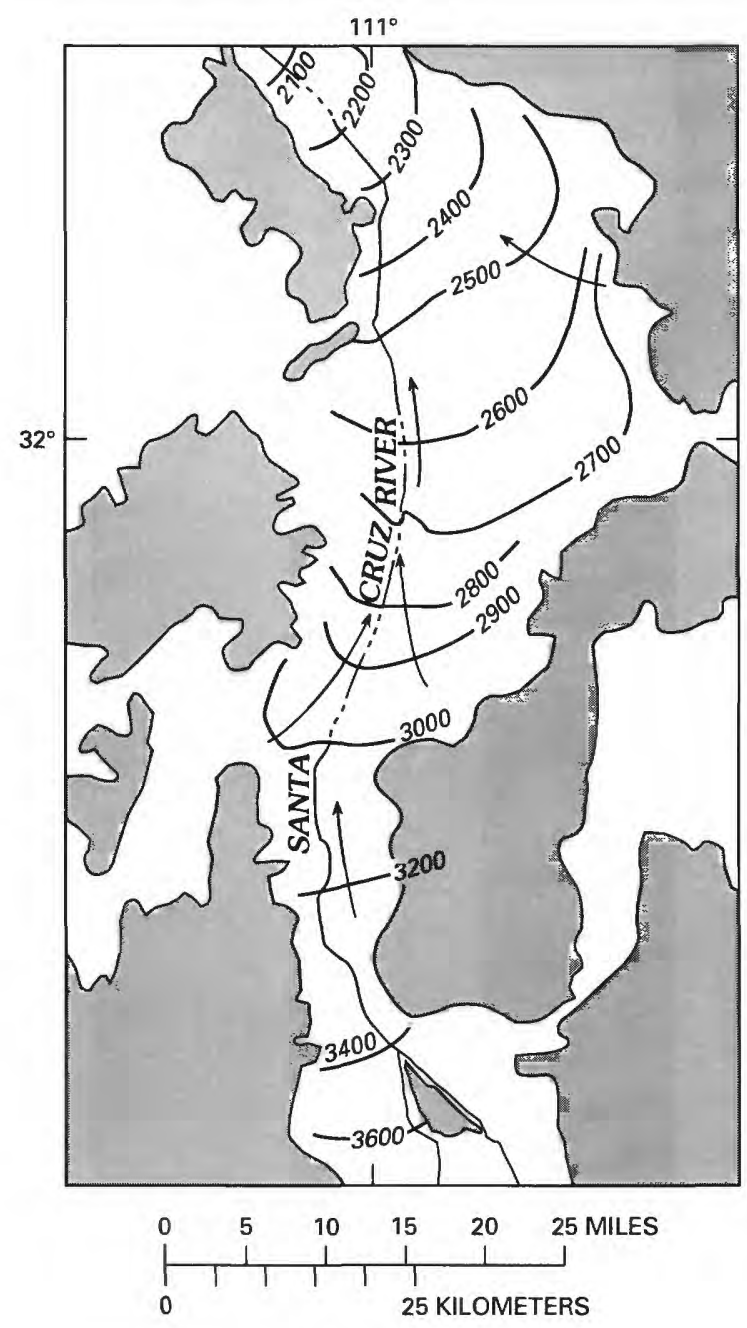

EXPLANATION

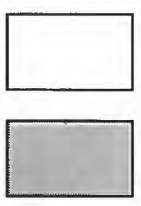

ALLUVIAL DEPOSITS

BEDROCK OF THE MOUNTAINS

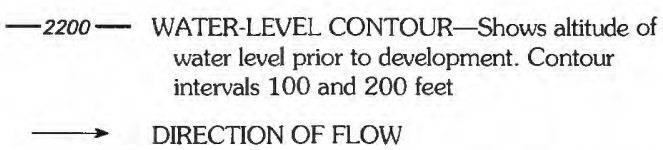

FIGURE 16.-U-shaped water-level contours that are indicative of multiple inflow and outflow components in the Tucson basin. annual unit downvalley flow for each basin. Generally, a basin with a high unit flow has more water available for development than a basin with a low unit flow. The lithology of the sediments that constitute the aquifers has a great influence on groundwater development. Lithofacies within the basin fill have different water-bearing properties, which affect ground-water movement and storage. Basin fill in most basins is composed of a similar lithologic sequence; however, because of areal differences in structural and depositional histories of the basins, the thickness of a particular lithologic unit varies throughout the study area. The result is differences in saturated thickness of the units; also, the unit within which the water table is located varies throughout the area. Consequently, the occurrence and movement of ground water and the response of the aquifer to ground-water withdrawal vary. A lithologic unit or facies of a unit that is composed of fine-grained sediments has the greatest control on the geohydrology. Given equal pumping stresses, a basin with an extensive fine-grained facies would have more adverse responses than a basin with a coarse-grained facies; those adverse responses include greater water-level decline, less recharge, and greater potential for inelastic compaction and associated land subsidence.

\section{DOWNVALLEY FLOW}

The hydrologic setting can best be expressed as a function of the annual unit downvalley flow of a basin. The quantity of downvalley flow represents the annually renewable water resources in the basin. The range of values of annual unit downvalley flow may exceed several million acre-feet per year in basins traversed by the Colorado River to basins where the annual unit downvalley flow probably is only a few hundred acre-feet per year.

The downvalley flow was estimated for each basin. The estimation was made on the basis of streamflow records, extent of phreatophytes estimated from 1930's aerial photographs, and precipitation-recharge relations as discussed previously. The estimated total downvalley flows were adjusted to fit the estimated regional water budget. Unit downvalley flow was derived from the estimated downvalley flow divided by the areal extent of the basin fill within the basin. Because the unit downvalley flow was to be used only for categorization, any discrepancy between the areal extent of basin fill and the actual areal extent of the aquifer was judged to be of similar proportion in all basins and therefore was 


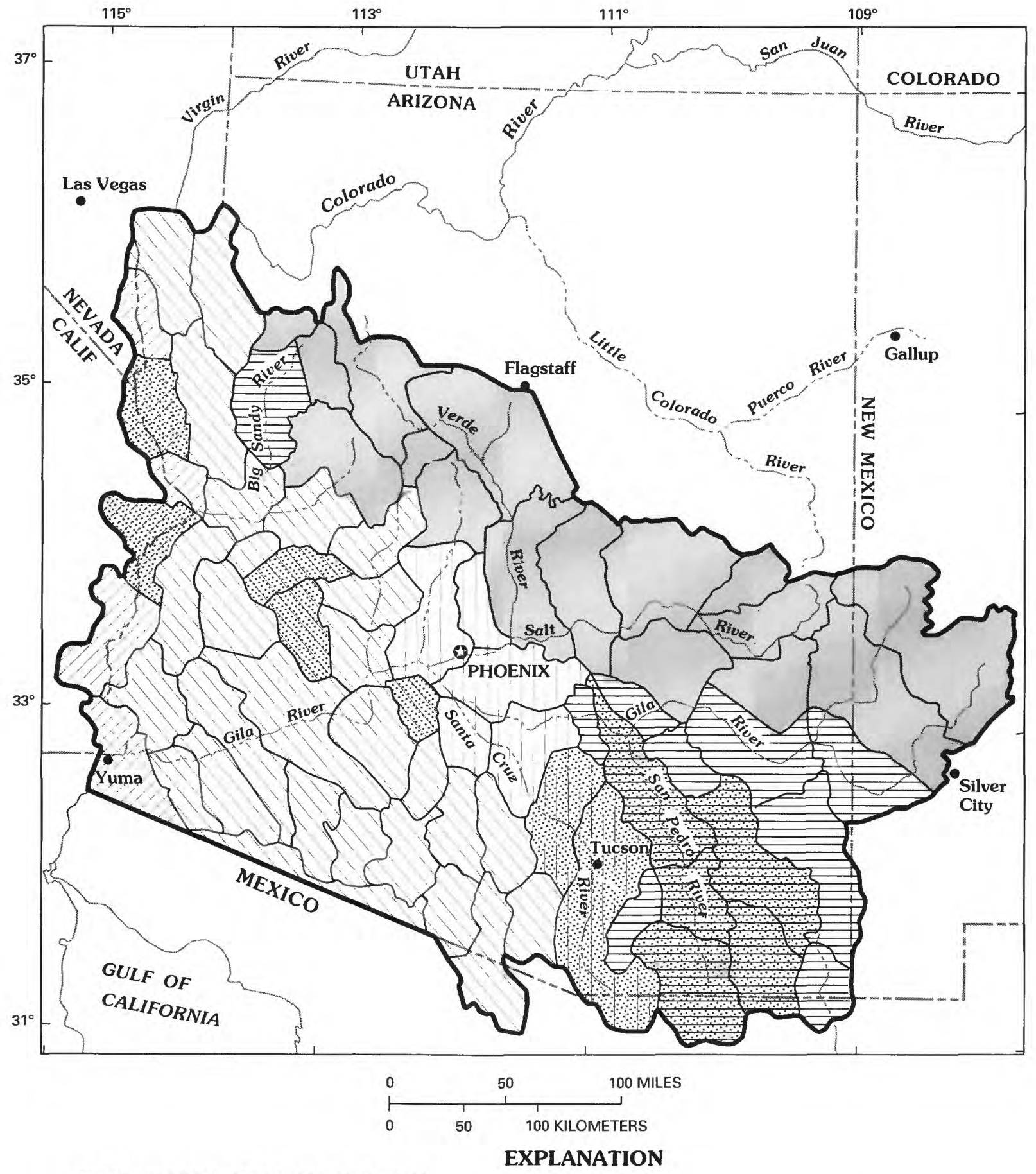

SUMMARY OF CATEGORIES OF BASINS

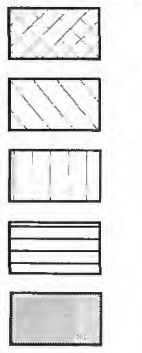

Colorado River

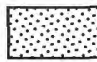

MODELED BASINS

West

BASIN BOUNDARY

Central

BOUNDARY OF STUDY AREA

Southeast

Highland

FIGURE 17.-Categories of alluvial basins based on geohydrologic factors. 
ignored. The annual unit downvalley flow for individual basins ranged from more than 10 (acre$\mathrm{ft} / \mathrm{acre}) / \mathrm{yr}$ in the northernmost basin traversed by the Colorado River to less than 0.001 (acre-ft/acre)/yr in Ranegras and La Posa Plains.

The basins were grouped into three broad categories on the basis of the magnitude of the annual unit downvalley flow. The groups are (1) river-dominated, (2) multiple source-sink, and (3) storage-depletion basins (fig. 18). Basins in the highland area were not included in the categorization by downvalley-flow criteria because of the differences in hydrologic setting and because of the limited areal extent of alluvium. Consolidated rocks underlie large parts of the highland basins and control most of the ground-water flow in those basins. Alluvium represents a minor part of the basin aquifers in the highland area and generally occurs in outflow areas of the consolidatedrock aquifers.

Basins in the river-dominated group have annual unit downvalley flows greater than 1.0 (acre$\mathrm{ft} / \mathrm{acre}) / \mathrm{yr}$ and are traversed by streams such as the Colorado River. The river-dominated basins principally are affected by streams in the basin. Ground-water pumping has limited effect on water levels because of the comparative immensity of surface-water resources and infiltration induced from surface flow. Basins in the multiple sourcesink group have unit downvalley flows that range from about 0.01 to 1.0 (acre-ft/acre)/yr and have multiple flow components of which one may be dominant. The response of the basin aquifers to pumping are dependent on location of the pumping wells and magnitude of pumpage in relation to location and magnitude of the basin inflow and outflow components. Basins in the storage-depletion group have annual unit downvalley flow of less than 0.01 (acre-ft/acre)/yr and have a total downvalley flow of less than 10,000 acre-ft/yr. Basin aquifers in this group rapidly undergo some degree of storage depletion after significant pumping begins.

The concept of using annual unit downvalley flow as a means to categorize the basins can be illustrated by the generalized relation of magnitude of annual unit downvalley flow to magnitude of potential development within a basin (fig. 19). The graph illustrates the potential effect in each group of basins. Three general responses are possible within the three categories of basins.

In river-dominated basins, the degree of development effect on the basin aquifers before depletion of aquifer storage is a function of the amount of available surface water in the stream and the proximity of wells to the stream (fig. 19). Colorado
River basins are an example of this category. Without considering legal controls on the downstream use of surface water, ground-water development near the Colorado River can increase infiltration from the river. The same relation could apply to small basins traversed by a perennial stream.

In multiple source-sink basins, surface water may be fully appropriated or consumed, and other sources of water, such as capture of natural discharges from evapotranspiration or ground-water underflow, may be available. For example, in the upper San Pedro Valley, as the pumping rate from wells has increased, a proportionally greater part of the pumpage is supplied by decreases in evapotranspiration and reductions in aquifer storage (Freethey, 1982).

In storage-depletion basins, almost all groundwater pumpage comes from aquifer storage (fig. 19). Recharge in storage-depletion basins is small and may be highly variable from year to year. As a result, water-level decline is associated with depletion of storage as development progresses.

The grouping of the basins on the basis of annual unit downvalley flow is applicable to predevelopment and development conditions, although certain basins may need to be reclassified following development. Reclassification would depend on the magnitude of the development compared to the magnitude of annual unit downvalley flow. As an example, the Salt River Valley was a riverdominated basin under predevelopment conditions. However, as development started, the river flow was controlled by reservoirs and the river flow was fully utilized. Minimal depletion of aquifer storage occurred at the beginning of the development and demands for water were almost completely met by downvalley flow. Under these conditions, the basin would be classified as a multiple source-sink basin. As development increased, the main source of ground water to meet the increasing demand was from aquifer storage; therefore, the basin would then be classified as a storage-depletion basin. McMullen Valley and Harquahala Plain are examples of basins in which storage depletion occurred as soon as an appreciable amount of ground water was withdrawn. In summary, a basin that is initially a river-dominated or multiple source-sink type will evolve toward a storage-depletion type as development increases (fig. 19).

One of the problems in categorizing basins on the basis of annual unit downvalley flow is that various parts of a basin may properly belong in different categories. The Salt River Valley is a good example. In low-lying areas along the Salt and Gila Rivers, the basin was river dominated and evolved 
under development to a multiple source-sink basin. $\mid$ could act as a storage-depletion basin. CategorizaAreas that are remote from the rivers, however, tion of an entire basin as a single entity, therefore,

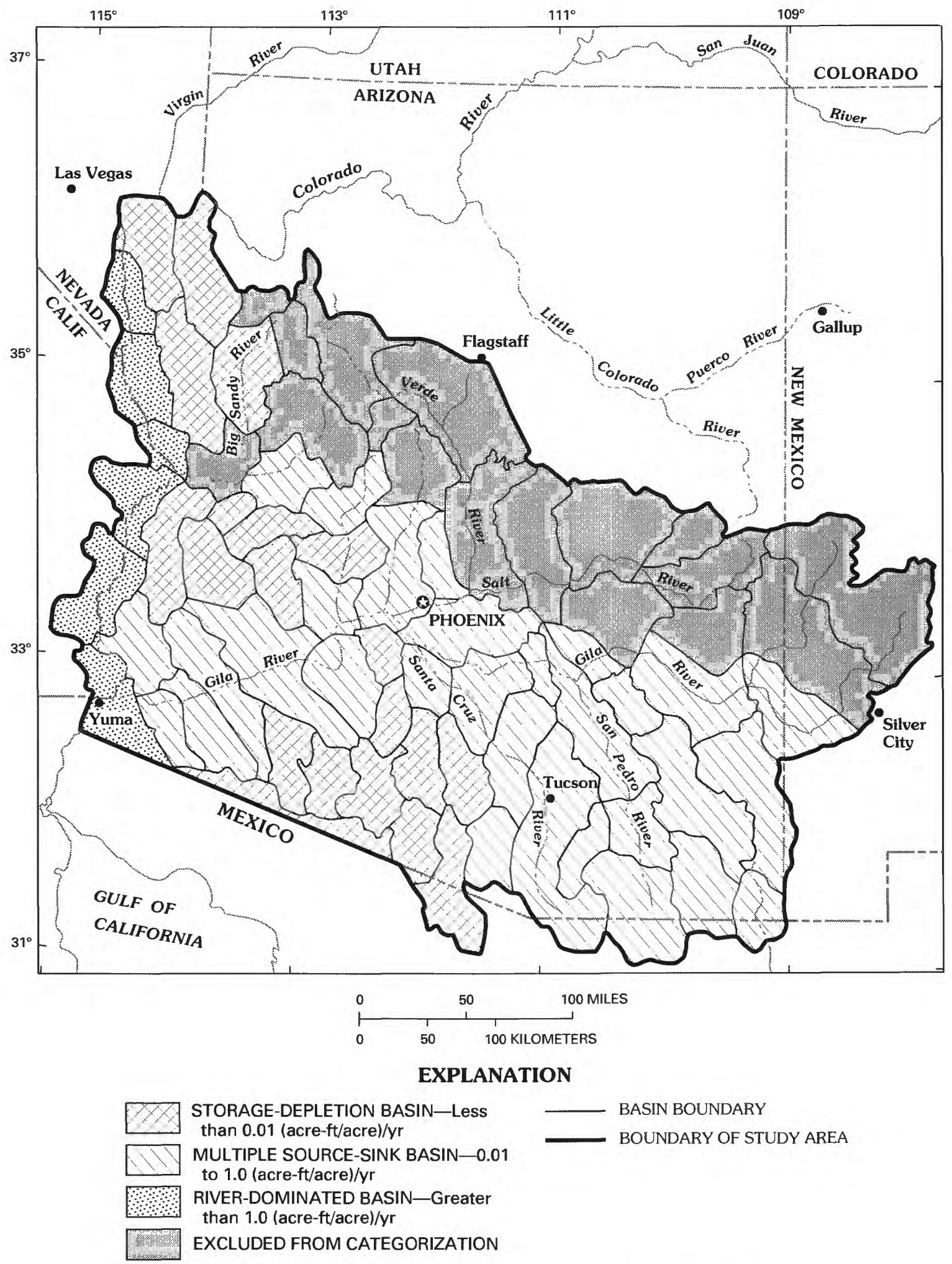

FIGURE 18.-Basin categories based on annual unit downvalley flow. 
is subjective and potentially misleading. Predevelopment categorization is based on the total annual unit downvalley flow; however, within the basin a large range in conditions may exist and locally any of the three basin categories may apply.

\section{LITHOLOGY OF BASIN SEDIMENTS}

The presence or absence of areally extensive units of low hydraulic conductivity is a major factor in the response of a basin aquifer to development. The
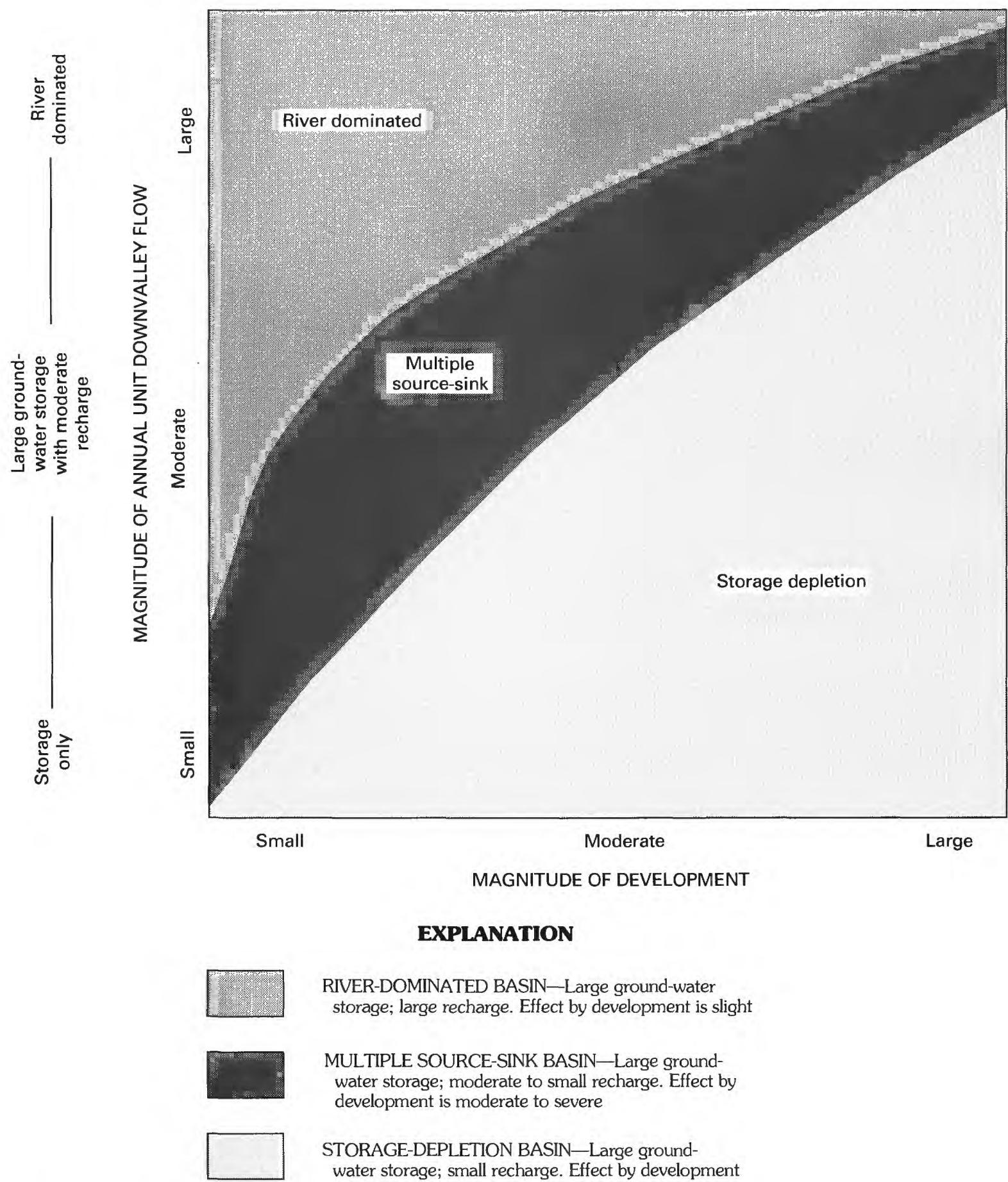

RIVER-DOMINATED BASIN-Large ground-water storage; large recharge. Effect by development is slight

MULTIPLE SOURCE-SINK BASIN-Large groundwater storage; moderate to small recharge. Effect by development is moderate to severe

STORAGE-DEPLETION BASIN-Large groundwater storage; small recharge. Effect by development is severe

Figure 19.-Conceptual relation of annual unit downvalley flow and magnitude of development in a basin. 
lithologic units of low hydraulic conductivity commonly are fine-grained facies of basin-fill sediments that include interlayered volcanics or evaporite deposits in places. The areal extent and integrity of these layers determine whether ground water in the major water-bearing sediments occurs under confined or unconfined conditions or as some combination of the two. Most basins have some combination of confined and unconfined conditions, depending on the thickness and areal extent of deposits that have low hydraulic conductivity.

Basins in which unconfined conditions occur are common; however, there are few in which the entire sedimentary sequence could be construed as a single, unconfined aquifer. In its simplest form, the most common unconfined aquifer occurs in the alluvium along major streams. The alluvium provides readily assessable and reliable sources of water before and during early stages of development. The few examples in which the principal aquifer is confined include San Simon Valley, San Bernardino basin, Empire Ranch area, and part of Little Chino Valley. Unconfined aquifer systems may have existed locally in these basins; however, they were of minor significance before development and are insignificant today.

Saturated stream alluvium is a narrow stringer of material that may be directly connected to the major aquifer (basin-fill sediments). Basins in which stream alluvium was a significant part of the basin aquifer generally are those that contained perennial streamflow before development occurred in the basin (fig. 20A). Stream alluvium has a high hydraulic conductivity and specific yield and probably receives a large part of recharge. Stream alluvium is the most significant part of the basin aquifer in the Colorado River basins. Stream alluvium is also a major part of the basin aquifer of the highland basins; however, the principal aquifer in the highland basins consists of consolidated rocks, which normally yield water to wells through fractures or joints and whose yields are highly variable from place to place.

All basins of the southeast, central, west, and Colorado River groups have an upper and lower unit of basin fill, but the thickness, areal extent, and integrity of the fine-grained facies in each unit varies throughout the study area. In general, the upper basin fill in the southeast basins includes a very fine grained facies composed of playa, lacustrine, and fluviolacustrine sediments. The central basins contain upper basin-fill sediments that tend to be moderately fine grained in the basin center (fig. 20B). In the west basins, the upper basin fill is thin, is coarser grained than in the central and southeastern basins, and commonly is above the water table.

In the center of a basin, fine-grained facies of the lower basin fill consists of mudstones, siltstones, evaporite deposits, and a small amount of coarser material. These fine-grained facies generally are divided into two groups-(1) deposits that contain 80- to 100-percent fine-grained material (less than $0.0625 \mathrm{~mm}$ in diameter) and (2) deposits that contain 55- to 80-percent fine-grained material (Freethey and others, 1986). The percentage of fine-grained materials is used as a description of the entire vertical sequence or a particular vertical segment of the lower basin fill. Units consisting of the 80 - to 100-percent fine-grained material mostly occur in the southeast and in a few basins in the central part and the northwestern part of the study area (fig. $20 \mathrm{C}$ ). Units consisting of the 55- to 80 -percent fine-grained material occur mostly in west basins and in some of the central basins (fig. $20 D$ ). Massive evaporites are associated with these fine-grained materials in some central basins and in a few basins adjacent to the Colorado Plateau. Locally, the lower basin fill also contains thin beds of volcanics interbedded with the fine-grained sediments. The coarse-grained facies of the lower basin fill and, in places, the upper part of the pre-Basin and Range sediments form the aquifer system in the southeast and west basins. The upper basin fill and, in places, the stream alluvium are the main water-bearing units of the aquifer in the central basins.

\section{SUMMARY OF BASIN CHARACTERISTICS}

Hydrology and geology of the basins are two principal factors that control the development of water resources in a basin. These two factors vary among basins. However, the basins can be divided into five groups-southeast, central, west, Colorado River, and highland-that have similar hydrologic and geologic characteristics.

\section{SOUTHEAST BASINS}

\section{LITHOLOGY}

The principal water-bearing deposits of the southeast basins are moderately thick pre-Basin and Range sediments and an overlying coarse-grained facies of lower basin fill, which may represent reworked pre-Basin and Range sediments in some 
places (fig. 21). The remainder of the lower basin fill is composed of fine-grained facies, generally greater than $1,000 \mathrm{ft}$ thick, that typically contain the 80 - to 100-percent fine-grained materials near the center of the basins. Upper basin fill generally consists of about $300 \mathrm{ft}$ of lacustrine and fluviolacustrine silts and clays and some limestone. Stream-alluvium deposits consist of thin layers of sand and gravel along major streams. Consolidated sedimentary rocks of the mountains may yield a small amount of water to wells for basins bounded by these rocks.

\section{HYDROLOGY}

In the southeast basins, the major inflow components are mountain-front recharge, stream infiltration, and some underflow from upgradient basins. Outflow consists of evapotranspiration, discharge to streams as base flow, and some underflow to downgradient basins. The basin aquifer consists of two or more water-bearing units separated by a finegrained unit that forms a leaky confining layer over the lower basin fill. Ground water occurs under confined conditions in the lower basin fill. Before development, the potentiometric surface was above the land surface in places resulting in flowing wells. Ground water in the stream-alluvium deposits is hydraulically connected to streams, which results in shallow water levels, high evapotranspiration losses, and extensive areas of phreatophytes. Ground water generally flows from the basin perimeter toward the central axis of the basin, where most discharge occurs. Depths to water range from above land surface in a few areas along perennial streams to more than $500 \mathrm{ft}$ at the basin perimeter.

\section{RESPONSE TO DEVELOPMENT}

Ground-water withdrawals in the southeast basins can continuously affect the magnitude of evapotranspiration, stream base flow, and stream infiltration (fig. 21C). Mountain-front recharge is not affected. Underflows can be moderately affected; however, due to its small magnitude the impact is not significant. Initial development in these basins results in an adjustment of all flow components and only minimal change in the volume of water stored in the aquifer material. Increased pumping will result in a corresponding increase in the volume of water withdrawn from storage until the major discharge components are captured as a result of large declines in water levels.

\section{CENTRAL BASINS}

\section{LITHOLOGY}

The depth to the base of water-bearing sediments in the central basins ranges from 8,000 to $12,000 \mathrm{ft}$ near the basin centers. Pre-Basin and Range sediments occur at great depth within the basins, and little is known of their extent or character. Lower basin fill, which is as much as $5,000 \mathrm{ft}$ thick in a few basins, consists of extensive fine-grained sediments. As defined earlier, the fine-grained sediments of the lower basin fill consist of two groups-a lower part that contains 80 - to 100 -percent fine-grained material and an upper part that contains 55- to 80-percent fine-grained material. The transition between these two groups is gradational. The 80 - to 100 -percent fine-grained material contains evaporite deposits that range from disseminated gypsum to massive halite. The 55- to 80-percent fine-grained material is as much as $1,000 \mathrm{ft}$ thick and becomes coarser toward mountain fronts. Upper basin fill consists of less than $1,000 \mathrm{ft}$ of sediments and includes basin-center deposits of more than 60 -percent fine-grained material. The fine-grained material of the upper basin fill grades laterally to coarse-grained material near mountain fronts. The sediments also grade vertically from fine grained at depth to coarse grained at land surface. Stream-alluvium deposits consist of as much as $300 \mathrm{ft}$ of coarse material along major streams.

\section{HYDROLOGY}

Inflow to the central basins consists of small to moderate amounts of mountain-front recharge and streamflow infiltration. Underflow in and out of the central basins is a significant component. Before development, ground-water discharge was mainly by evapotranspiration, with minor discharge to streams as base flow (fig. 22). The principal water-bearing sediments consist of stream-alluvium deposits, where saturated, and upper basin fill. Ground water occurs under unconfined conditions, although head differences with depth may occur because of the presence of clay lenses in the heterogeneous basin fill. Before development, water levels ranged from at land surface near perennial streams to as much as $700 \mathrm{ft}$ below land surface in places near mountain fronts. Ground water flows from the perimeter of a basin and from the upgradient end toward the basin center and then downvalley to the outflow point at the downstream end of a basin. Some ground water flows through the entire length of the basins. 

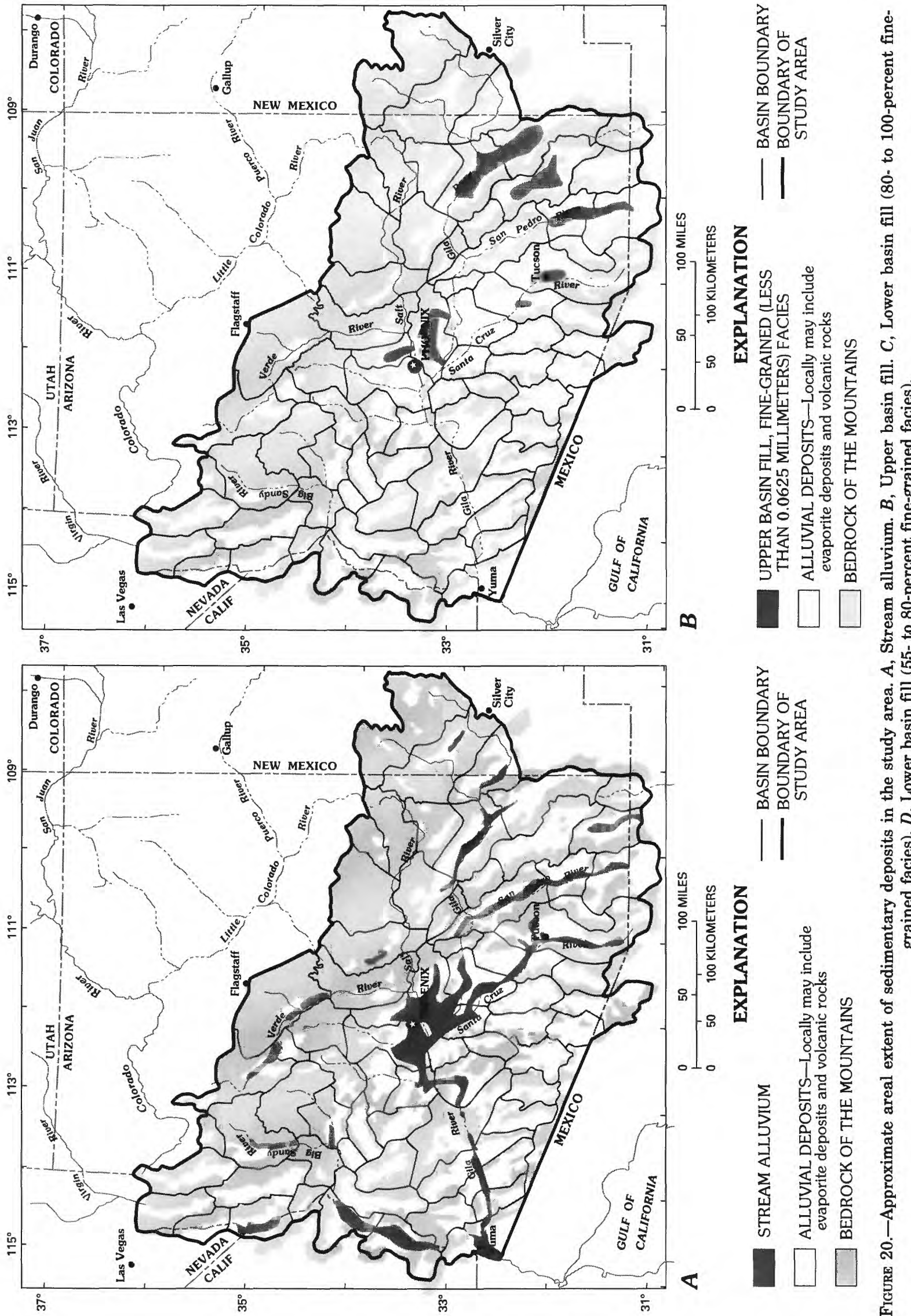

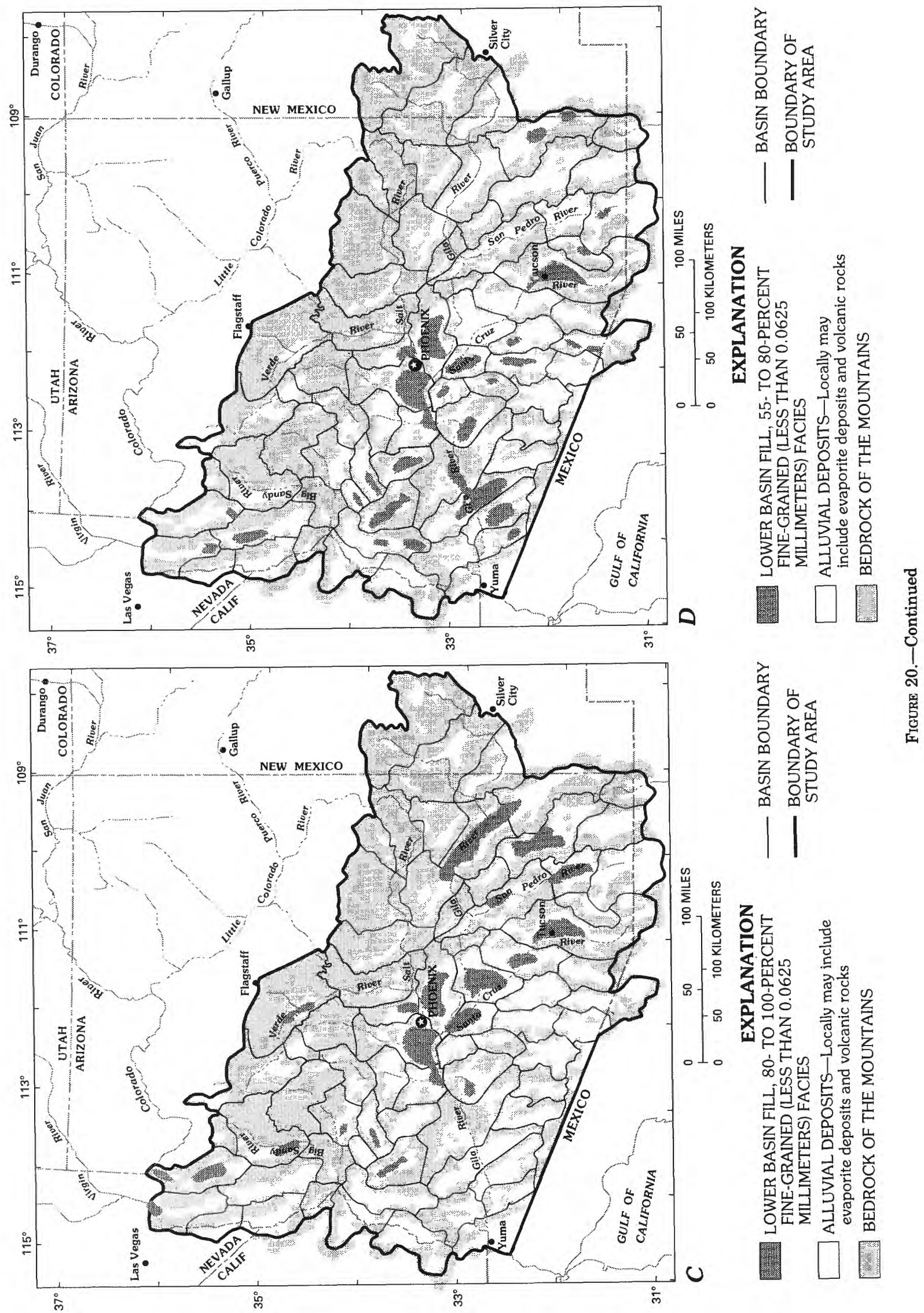


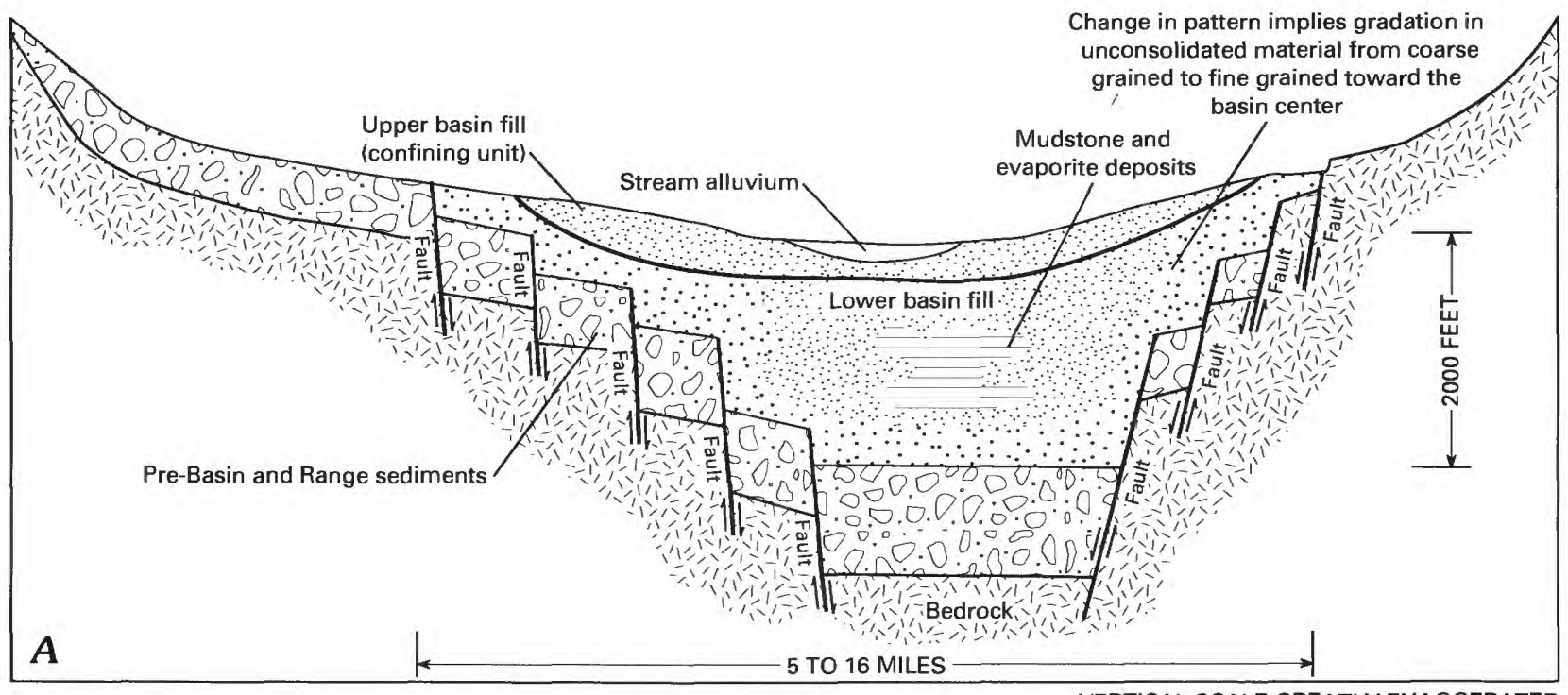

VERTICAL SCALE GREATLY EXAGGERATED
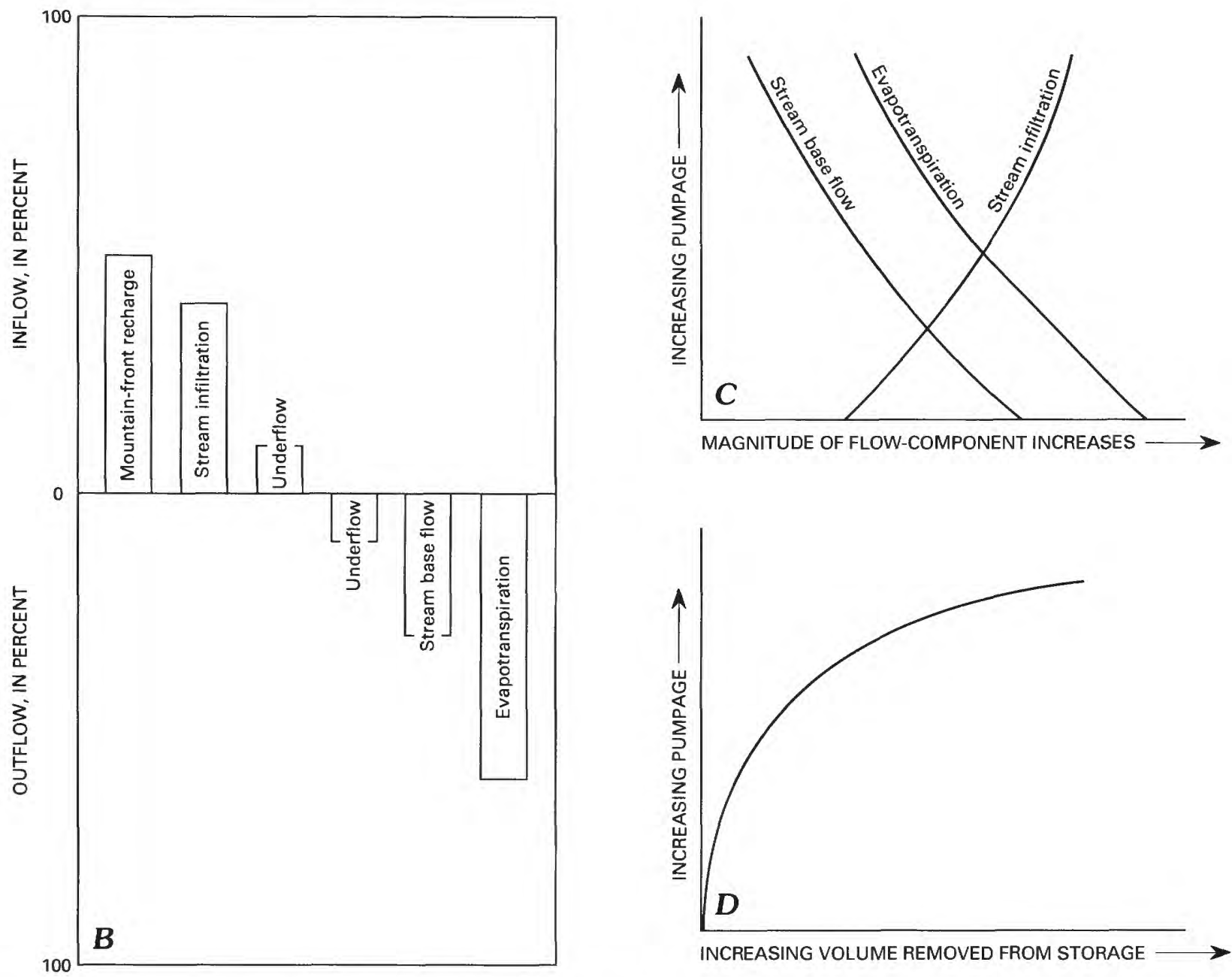

Figure 21-Generalized geologic and hydrologic characteristics of the southeast basins. $A$, Physical system. $B$, Water budget before development. $C$, Flow-component response to pumping. $D$, Change in storage in response to pumping. 

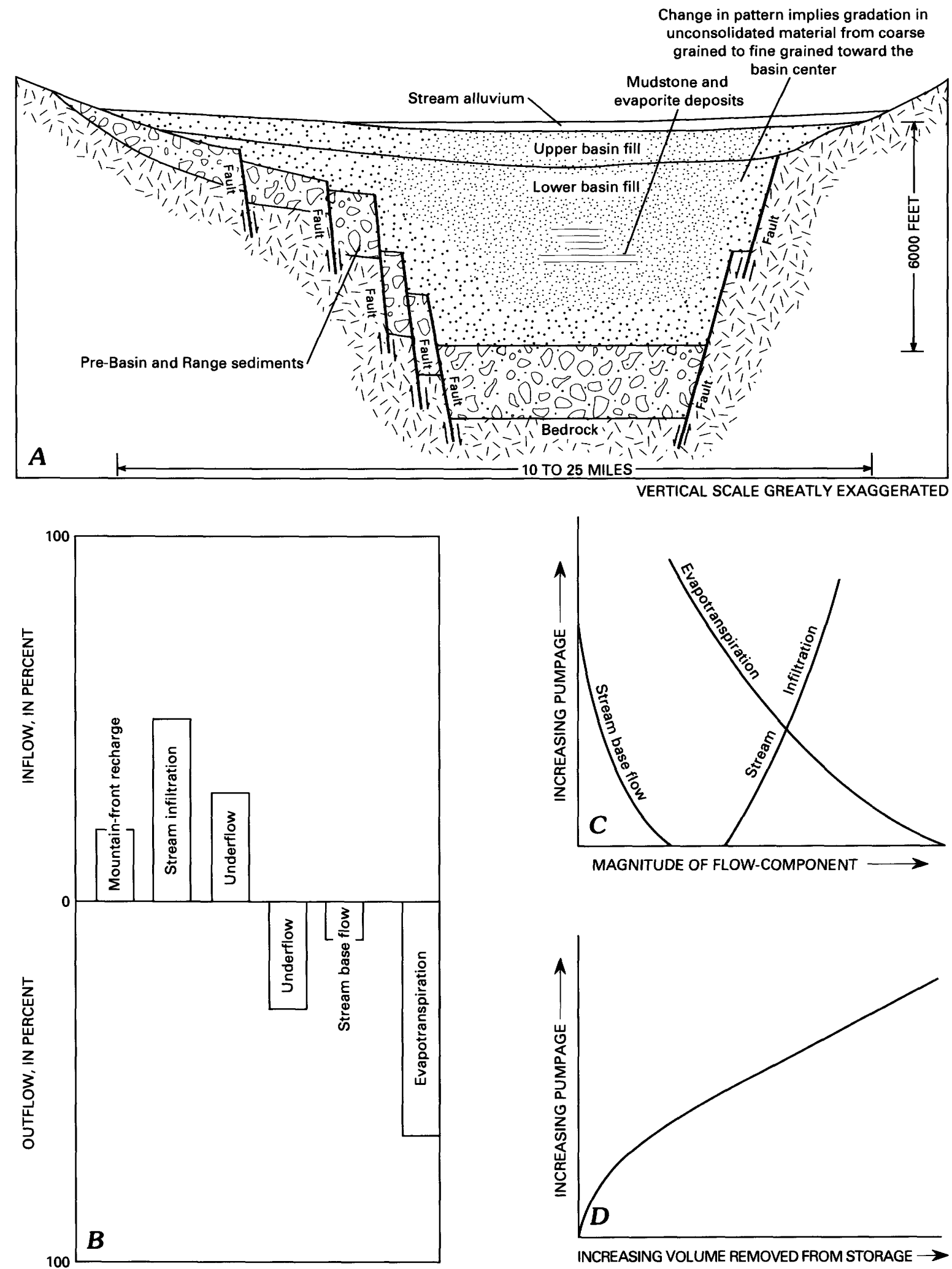

FIGURE 22.-Generalized geologic and hydrologic characteristics of the central basins. $A$, Physical system. $B$, Water budget before development. $C$, Flow-component response to pumping. $D$, Change in storage in response to pumping. 


\section{RESPONSE TO DEVELOPMENT}

Pumping in the central basins has captured evapotranspiration and stream base flow. Surfacewater infiltration has increased locally because a larger volume of sediments is available for storage. Mountain-front recharge has not been affected by development. Most ground water is derived from storage within the aquifer, and water levels have declined as much as $450 \mathrm{ft}$. Some additional recharge reaches the water table from the application of irrigation water in excess of the plant requirements and from canal leakage. However, the source of the irrigation water is predominantly ground water pumped from the basin aquifer; therefore, this recharge of irrigation return flow and canal leakage constitutes recycling and redistribution of some ground water within the basin. In most pumping areas groundwater levels are declining; however, in localized areas the rate of decline may be reduced by the recharge of the irrigation return flow. Some water levels in the irrigated areas may also remain relatively stable owing to reduced pumping and recharge of excess applied irrigation water.

\section{WEST BASINS}

\section{LITHOLOGY}

Pre-Basin and Range sediments occur at shallow depths in the west basins (fig. 23) and are overlain by lower basin fill, which consists of a medium- to coarse-grained facies and an overlying facies containing 55- to 80-percent fine-grained material. Upper basin fill is thin and heterogeneous. Streamalluvium deposits are limited to areas along the lower Gila River.

\section{HYDROLOGY}

The west basins include the most arid part of the study area. Inflow to the basins is minimal and is composed of minor amounts of mountain-front recharge and infiltrated flow from streams. Underflow in and out of the basins is a significant flow component, however, it is limited in magnitude. Outflow consists of small amounts of evapotranspiration at the extreme downstream end of the basins; stream base flow is practically nonexistent. The basin consists of the lower coarse-grained facies of lower basin fill and at least the upper part of pre-Basin and Range sediments.

For the most part, the upper basin fill is above the water table. In a few basins, especially along the
Gila River, stream-alluvium deposits are productive water-bearing sediments but only significant locally. Before development, the sediments of the basins functioned hydrologically as a single aquifer. After development, the sediments may function as two distinct hydrologic units because a fine-grained facies occurs near the middle of the lower basin fill. Ground water flows downvalley and depths to water range from a few feet below the land surface to more than $1,300 \mathrm{ft}$ near mountain fronts.

\section{RESPONSE TO DEVELOPMENT}

The inflow and outflow to the west basins are extremely limited and do not represent a substantial source of water as withdrawals increase. Groundwater pumpage is derived almost exclusively from storage within the aquifer. In the areas immediately adjacent to the Gila River, ground-water development may result in capture of evapotranspiration losses.

\section{COLORADO RIVER BASINS}

\section{LITHOLOGY}

The Colorado River basins include the Miocene(?) fanglomerate overlain by the Bouse Formation. Older alluvial deposits overlie the Bouse Formation, and stream alluvium overlies and occupies channels cut into the older alluvium (fig. 24). The Miocene(?) fanglomerate is described as being "composed chiefly of cemented sandy gravel" (Metgzer and others, 1973, p. 10) and is present in all the basins along the lower Colorado River. The Bouse Formation unconformably overlies the fanglomerate and is a marine estuarine deposit equivalent to upper basin fill deposited in an embayment of the Gulf of California (Metzger, 1968).

\section{HYDROLOGY}

The occurrence and movement of ground water in the Colorado River basins are totally dominated by the amount of streamflow in the Colorado River. Infiltration of water from the river represents the main source of inflow to the basin aquifers of the Colorado River basins. Underflow and mountainfront recharge are small as compared with the infiltration from the river and are negligible in most basins. Ground-water outflow is almost entirely through consumptive use by phreatophytes and 


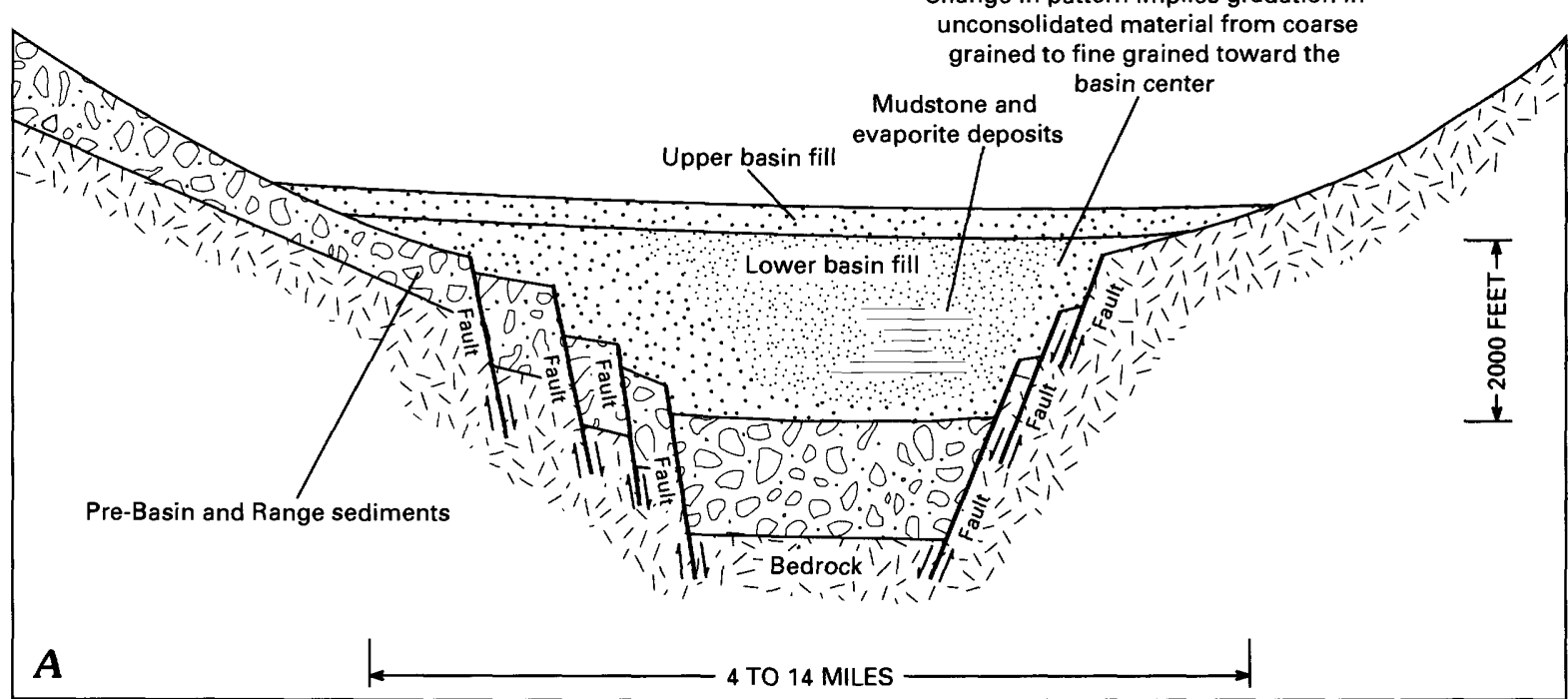

VERTICAL SCALE GREATLY EXAGGERATED
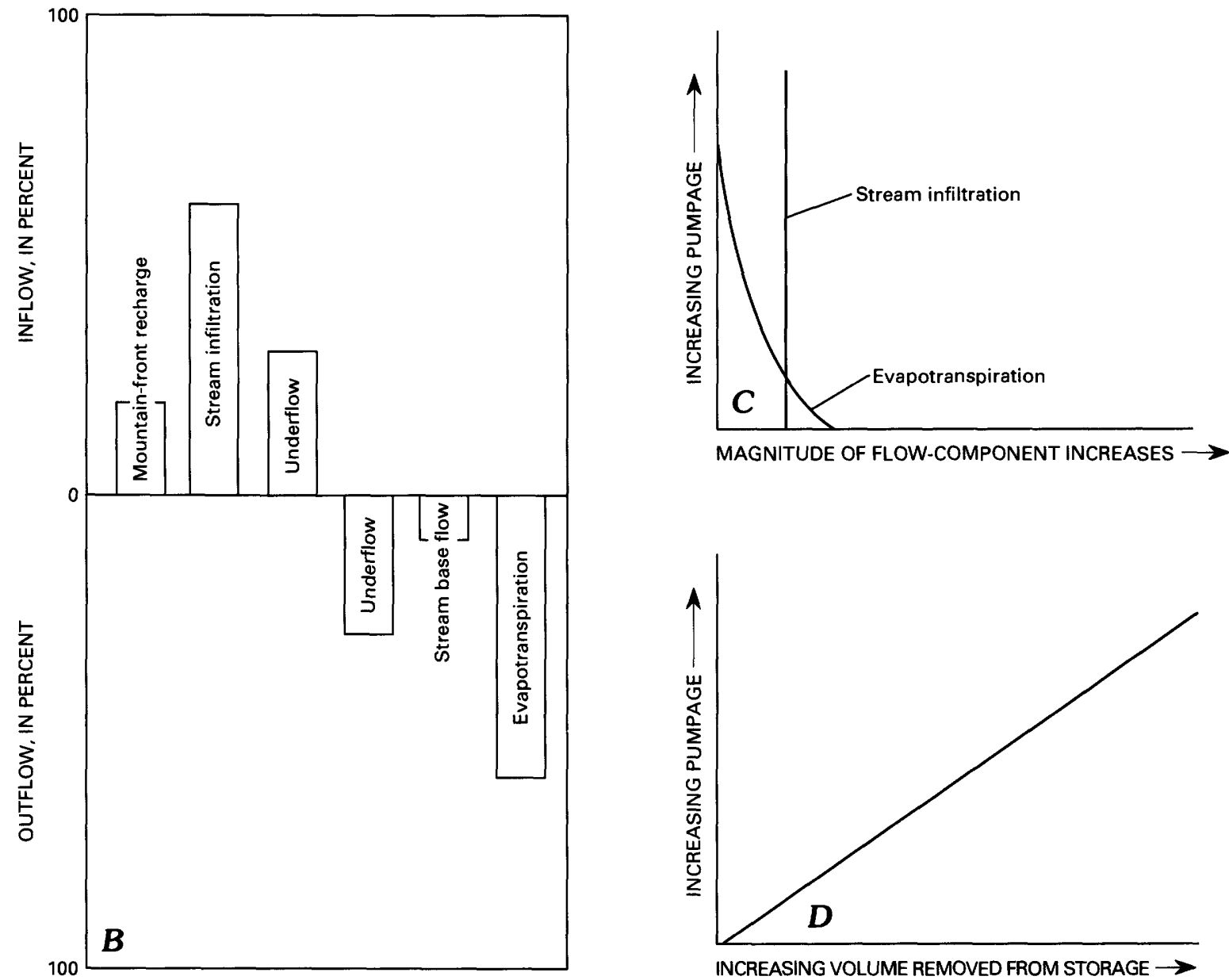

Figure 23.-Generalized geologic and hydrologic characteristics of the west basins. $A$, Physical system. $B$, Water budget before development. $C$, Flow-component response to pumping. $D$, Change in storage in response to pumping. 

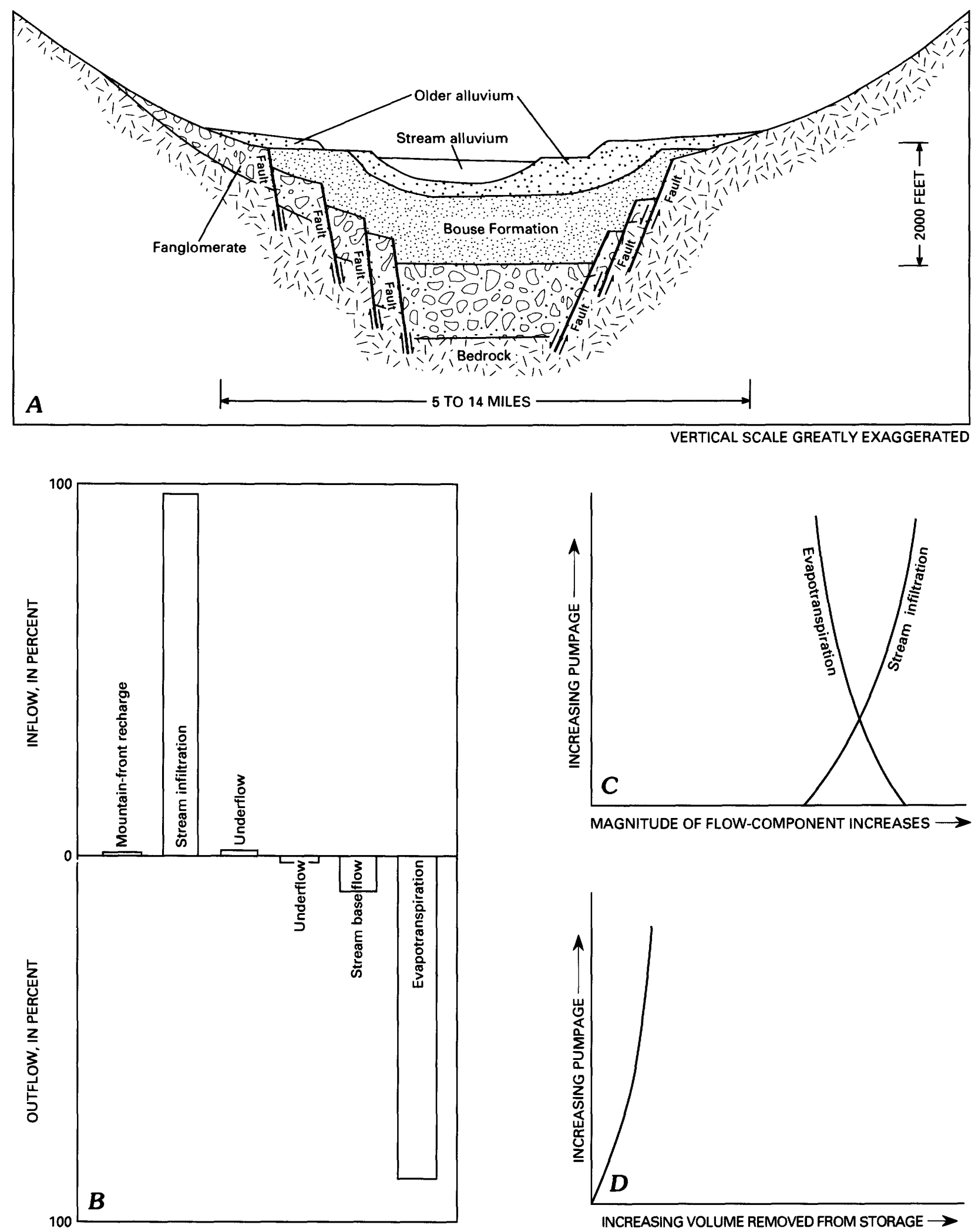

FIGURE 24.-Generalized geologic and hydrologic characteristics of the Colorado River basins. $A$, Physical system. $B$, Water budget before development. $C$, Flow-component response to pumping. $D$, Change in storage in response to pumping. 
riparian vegetation. A minor amount of underflow occurs in a few basins. The aquifer consists principally of the stream-alluvium deposits underlying the flood-plain area. Older alluvium that lies beyond the flood plain is hydraulically connected to the sediments underlying the flood plain and is part of the aquifer. Hydraulic conductivity of the older alluvium is lower than that of stream alluvium because the older alluvium is more cemented and more indurated. Ground water occurs under unconfined conditions in the stream alluvium and older alluvium as well as in the upper part of the Bouse Formation. Ground water occurs under confined conditions in the underlying fanglomerate; however, the fanglomerate has not been developed as a source of water because of the availability of water in the upper sediments. The water table ranges from at land surface adjacent to the Colorado River to a few hundred feet below land surface. Ground-water flow occurs laterally in the basins away from the river toward the discharge area, which is the entire flood plain where evapotranspiration prevails; some ground water also flows parallel to the Colorado River.

\section{RESPONSE TO DEVELOPMENT}

Ground-water withdrawal in the Colorado River basins will have minimal effects on water levels because of the immensity of the quantity of water that infiltrates to the aquifer from the river. Ground water that is pumped from the flood plain is mostly derived from water in the river, which infiltrated a few days to months previously. Locally, evapotranspiration could be decreased by lowering the water table. This lowering of the water table also increases the hydraulic gradient from the river, which would result in additional infiltration from the river. Only a minor amount of water would be removed from aquifer storage. Where surface water is used for irrigation, water levels have risen to within a few feet of land surface. Locally, the hydraulic gradient in the area irrigated by surface water has been reversed, and ground water flows toward the river.

\section{HIGHLAND BASINS}

\section{LITHOLOGY}

The highland basins contain as much as $500 \mathrm{ft}$ of basin-fill sediments that are limited in areal ex- tent. These sediments typically are superimposed on a sequence of pre-Cenozoic sedimentary rocks (fig. 25). The Verde Formation in Verde Valley is a basin-fill equivalent and consists of heterogeneous lake deposits that include limestone, mudstone, and sandstone (Twenter and Metzger, 1963). Little is known about the lithology of the basin fill in other basins of the highland group because of the few wells that penetrate the unit. The basin fill sediments were deposited in downdropped basins formed in the consolidated rocks. These basins were limited in areal extent and were subsequently filled with locally derived erosional material that now forms the basin-fill unit. Stream alluvium, which overlies the basin fill, is common along the flood plains.

\section{HYDROLOGY}

The basin aquifers consist of basin fill and stream alluvium, which are hydraulically connected. The aquifers are limited in areal extent and have large amounts of ground water in storage compared to the consolidated-rock aquifers beneath and surrounding the basin aquifers. Inflow to the basin aquifers includes underflow from the adjacent consolidated-rock aquifers and infiltration from streams. Mountainfront recharge probably also occurs in places. Ground-water discharge occurs as evapotranspiration and as base flow to streams. Because of the discontinuous nature of the basin aquifers in the highland group; underflow from one basin aquifer to another basin aquifer does not occur. Ground water generally occurs under unconfined conditions. Depth to the water table ranges from at land surface to a few tens of feet below land surface.

\section{RESPONSE TO DEVELOPMENT}

Ground-water withdrawals in the highland group could result in increased streamflow infiltration, decreased base flow, decreased evapotranspiration, or a combination of these effects. Mountain-front recharge and underflow into the aquifers will not be affected by pumping from the aquifers. As water is withdrawn from storage, additional streamflow may infiltrate to fill the volume temporarily dewatered. As long as the total withdrawal does not exceed the stream base flow, the stream will continue to contain perennial flow and no long-term decline of water levels in the basin aquifers will occur. When withdrawals exceed the magnitude of stream base flow, the stream will become 


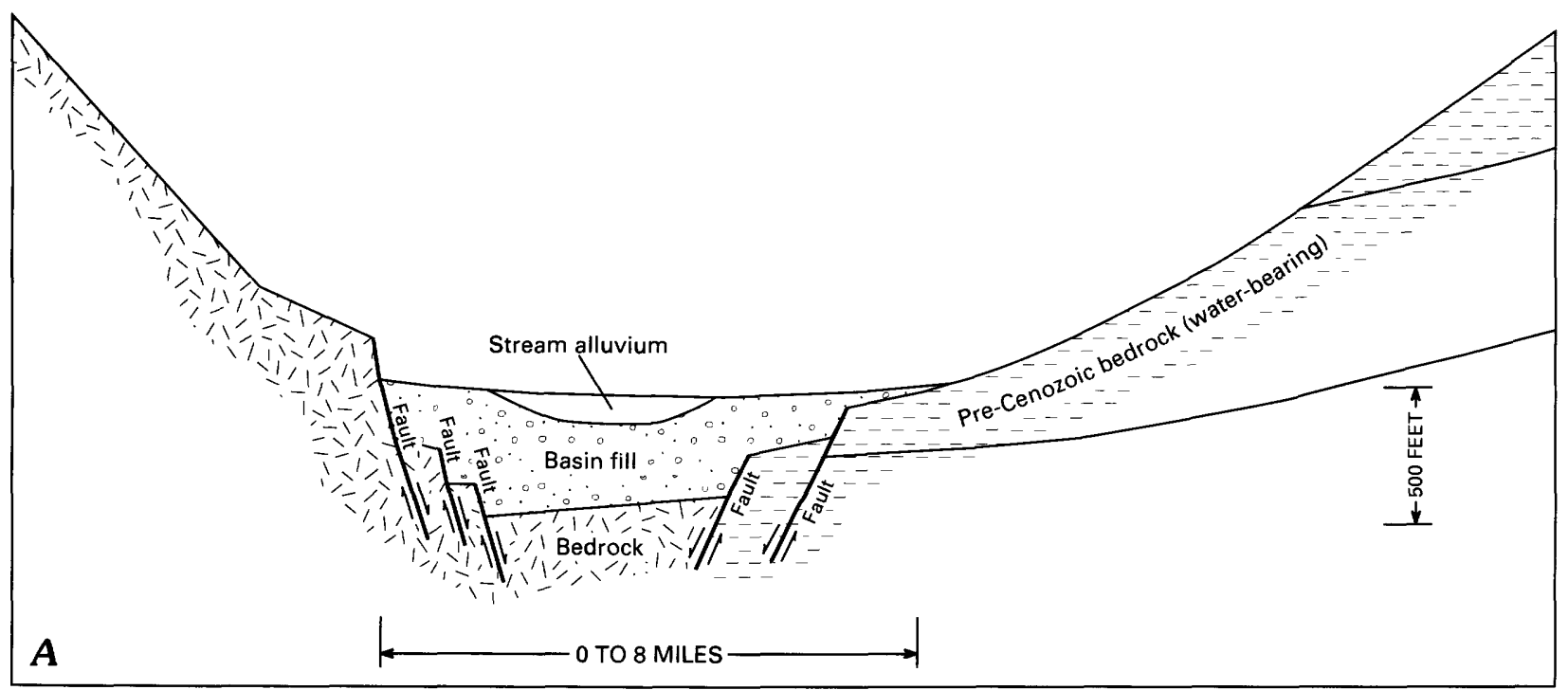

VERTICAL SCALE GREATLY EXAGGERATED
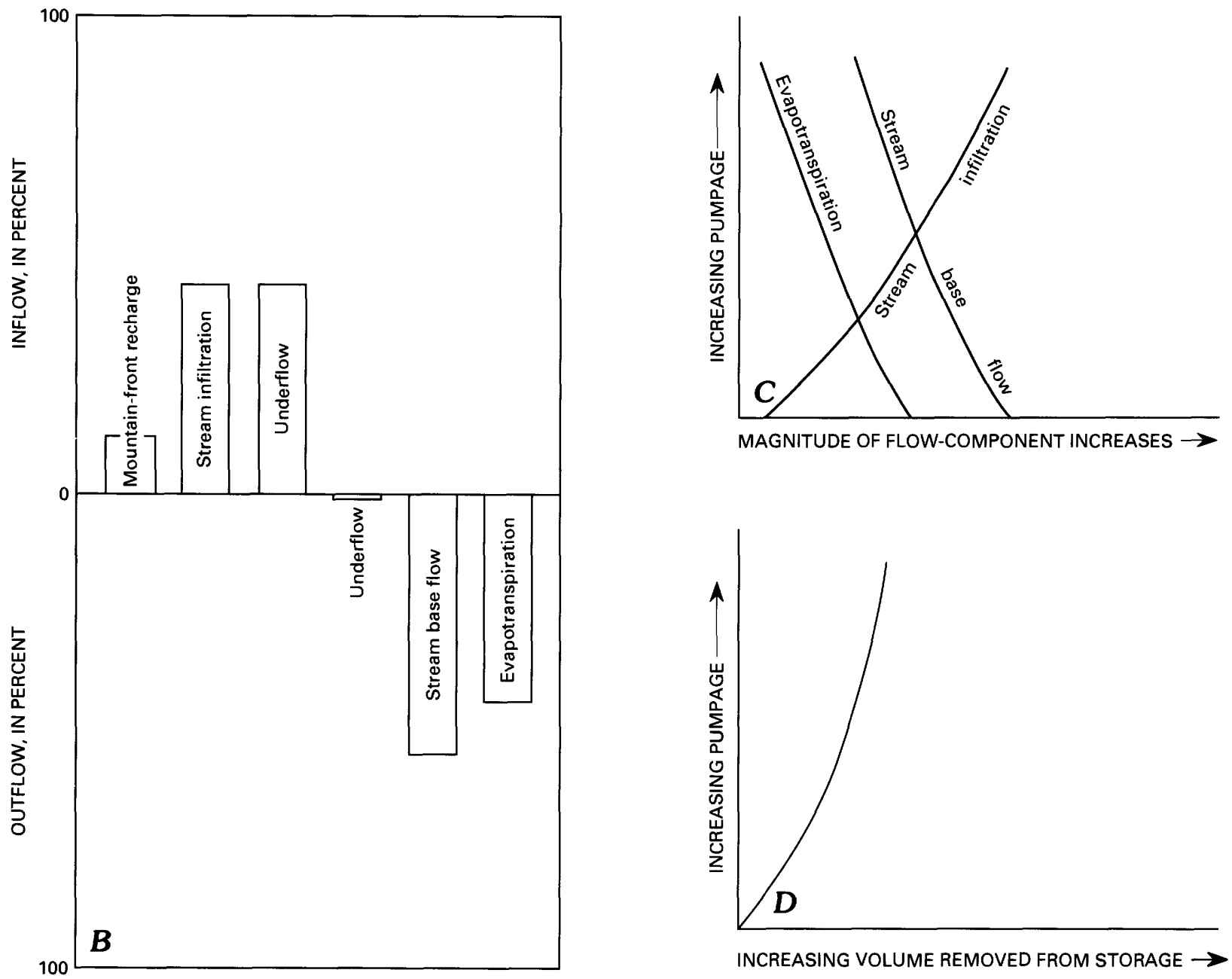

INCREASING VOLUME REMOVED FROM STORAGE $\rightarrow$

FIGURE 25.-Generalized geologic and hydrologic characteristics of the highland basins. $A$, Physical system. $B$, Water budget before development. $C$, Flow-component response to pumping. $D$, Change in storage in response to pumping. 
ephemeral and water levels in the basin aquifers will decline, at least on a seasonal basis.

\section{WATER-RESOURCES DEVELOPMENT AND EFFECTS ON HYDROLOGIC SYSTEM}

Many of the effects of water-resources development in the study area are a result of uneven spatial and temporal distribution of the availability of water. Water-resource development partially alleviates the problem of distribution through regulation of streamflow. Ground water was developed initially as a supplement to the surface-water supply to dampen the temporal variability. Additional ground-water development was designed to overcome some of the spatial variability especially where surface-water supplies were not available.

Large volumes of ground water are in storage and can be readily withdrawn for use. Historic withdrawals of over 184 million acre-ft through 1980 have resulted in a reduction in stored water in aquifers of nearly 100 million acre-ft throughout the study area. During this study it was estimated, on the basis of available hydrologic and geologic data, that depletion of the volume of ground water in aquifer storage in a basin through 1980 ranged from less than 1 percent to as much as 15 percent of the total volume of water in storage. The immediate question of developing ground water in the study area, therefore, is not one of running out of water; however, the amount of ground water in aquifer storage is limited. If the magnitude, distribution, and duration of groundwater withdrawals exceed natural recharge, then overdevelopment of the basin aquifer will occur. However, the degree of overdevelopment is a function of the hydrologic factors within the basin and the magnitude of development.

Overdrafts of water from basin aquifers have caused water levels to decline throughout most of the developed areas. The effects on water levels that accompany overdraft of ground water include the need to continually deepen wells and install new high-lift pumping equipment. This causes increases in capital investment, in maintenance costs, and in costs of pumping. Another serious consideration is the decrease in well yield with depth; although not strictly the case in every basin, decreased well yield may be considered a general trend in many basins. Physical problems that accompany overdraft of ground water include land subsidence and earth fissuring in some basins that have thick, compressible fine-grained sediments accompanied by large water-level declines. Finegrained sediments tend to compact as the buoyant effect of water is removed and the effective overburden increases. Water-quality problems may also develop. The most common problem will be the effect of variable water quality with depth in many basins. In addition, contamination from development activities can effectively reduce the availability of a usable water supply.

The magnitude of these effects can be magnified if the development of water resources in basins is not regulated and managed. Such was the case in the 1940 's through 1960's. Currently, the development and management of the water resources is regulated by the Arizona Groundwater Management Act of 1980 (Arizona Groundwater Management Study Commission, 1980). Mandatory water conservation and management are integral parts of the act, which are essential to the maintenance of reliable groundwater supplies.

\section{WATER-LEVEL DECLINE}

Removal of water from aquifer storage at a rate in excess of the natural rate of replenishment has resulted in widespread water-level declines. Declines of 50 to $100 \mathrm{ft}$ have occurred throughout large parts of developed basins (pl. 2). Through 1980, the maximum long-term water-level decline exceeds $450 \mathrm{ft}$ in the Stanfield area and is more than $420 \mathrm{ft}$ southeast of Chandler (Laney and others, 1978). Declines of more than $200 \mathrm{ft}$ by 1980 occurred in Harquahala Plain, McMullen Valley, Willcox basin, San Simon Valley, and extensive parts of the Eloy and Stanfield basins and the east and west parts of the Salt River Valley.

Historic changes in water levels in selected basins and for selected time periods are shown in figure 26. As shown in the hydrograph representing the Stanfield basin, the water level in a well in sec. 1, T. 6 S., R. 2 E. (fig. $26 A$ ), declined at a rate of nearly $24 \mathrm{ft} / \mathrm{yr}$ during the 1950 's, about $17 \mathrm{ft} / \mathrm{yr}$ during the 1960 's, and only $8 \mathrm{ft} / \mathrm{yr}$ during the 1970's. The well is near the edge of the basin and the large water-level decline rate reflects the boundary effect of the virtually impermeable consolidated rock on the basin perimeter. The decreasing rate of water-level decline in recent years probably reflects the decreased pumpage in the area. Pumping levels are more than $700 \mathrm{ft}$ below the land surface, and the increase in pumping costs during recent years probably resulted in a decrease in irrigated acreage or a switch to crops that use less water.

Maximum water-level decline rates of about 18 $\mathrm{ft} / \mathrm{yr}$ occurred in places in the Salt River Valley 

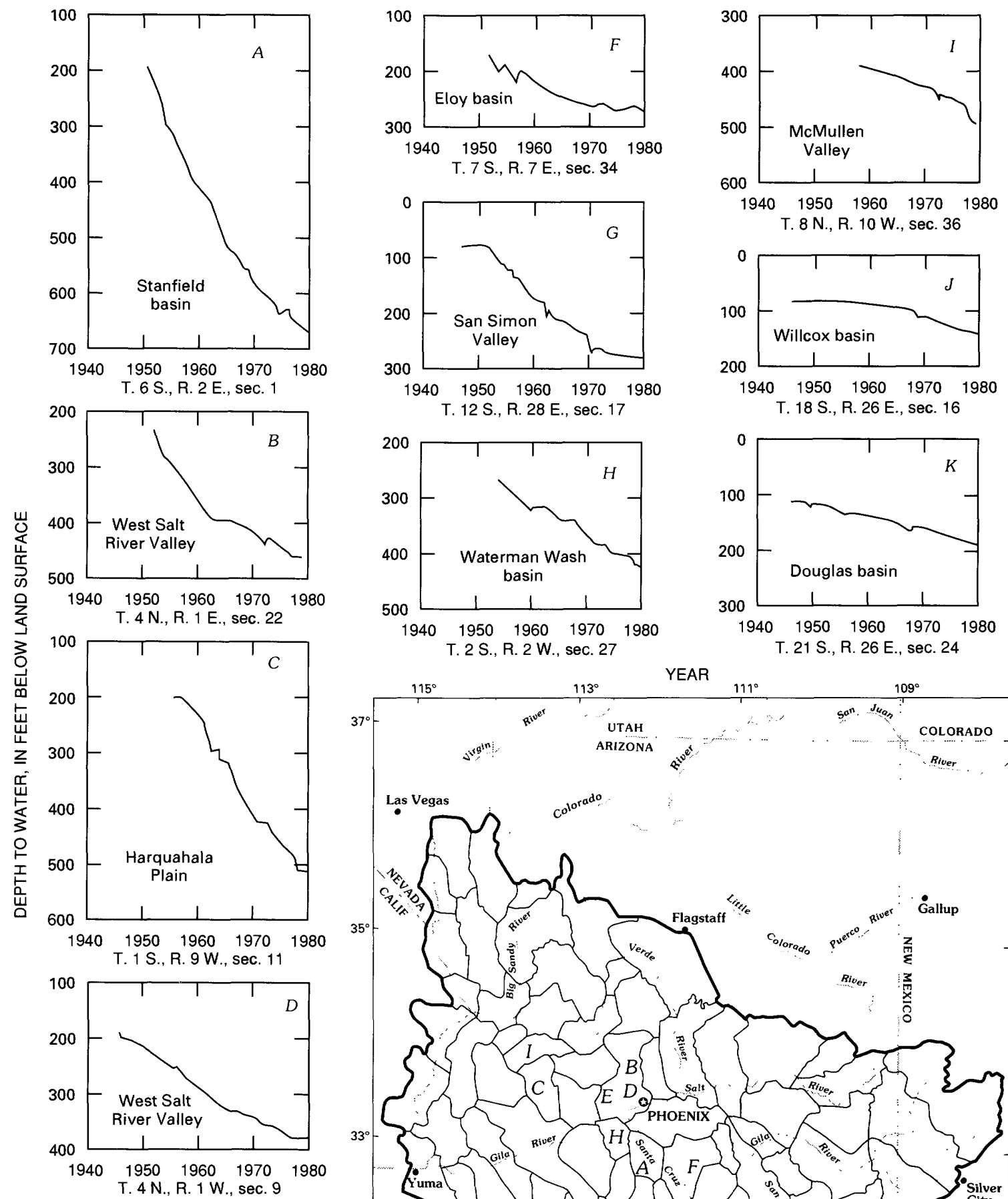

$35^{\circ}$
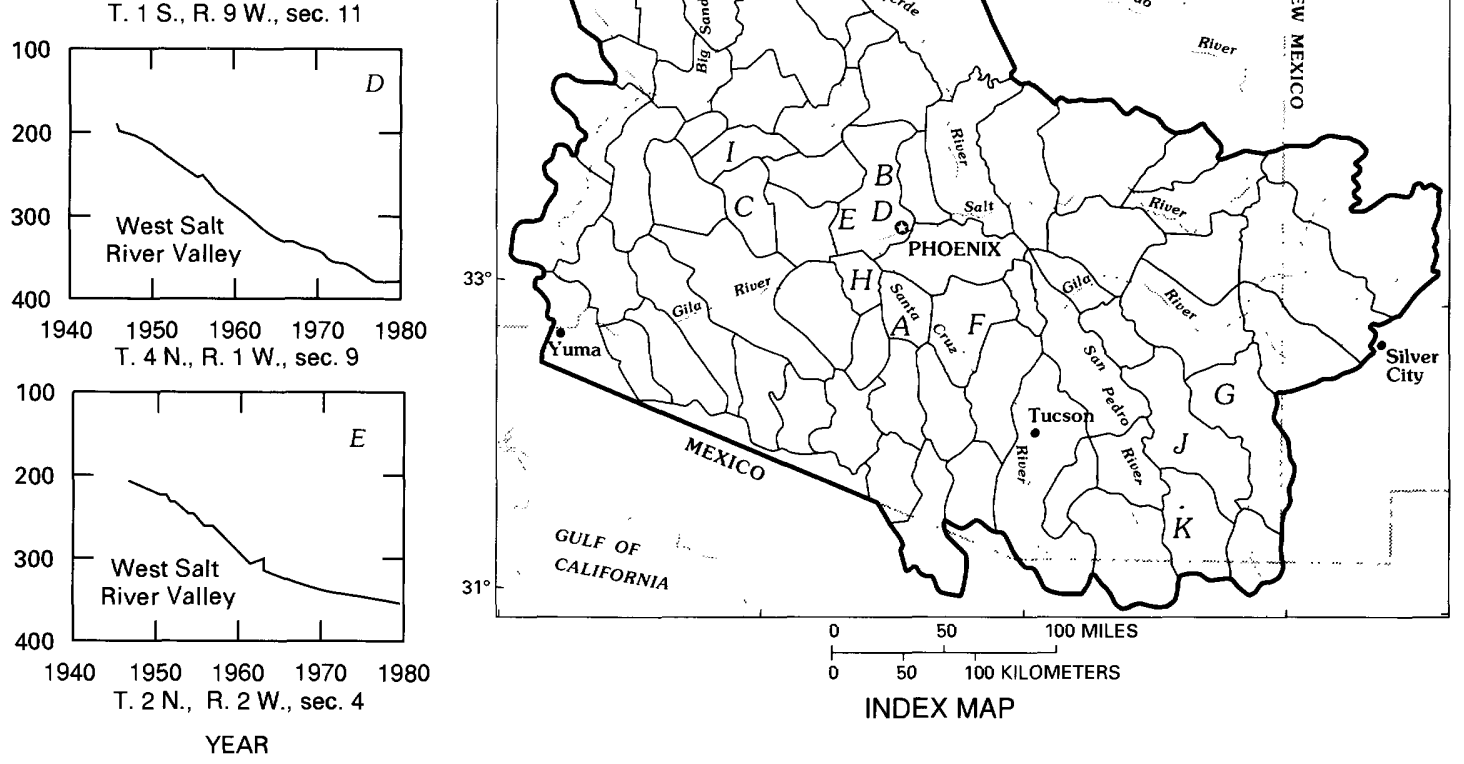

FIGURE 26.-Historical changes in water levels in selected wells. Letters referred to in text. 
(fig. 26B) and in places in the Harquahala Plain (fig. 26C) during the late 1950's and early 1960's. In recent years, the decline rate has decreased because of decreased pumpage, which is mainly a result of economic considerations. Rates of waterlevel decline lessened in the late 1960's and 1970's in several highly developed basins such as Salt River Valley (fig. $26 D, E$ ), the Eloy basin (fig. $26 F$ ), and San Simon Valley (fig. 26G). In places, the decreases in water-level decline rates can be attributed to decreased pumpage; however, in other places, changes in inflow to the basin aquifers may be a contributing factor.

Primary change in inflow rate may be due to recharge from excess applied irrigation water and infiltration from canals. Because of the nature of the fine-grained sediments in most basins, long-term drainage from them may also influence the relation between pumpage and water-level declines. Inelastic compaction of thick, fine-grained sediments may also be a source of additional water drained from the aquifers. This additional amount of water could be significant, but the exact quantity is unknown. The volume of land subsidence is equal to the volume of water derived from the fine-grained sediments by inelastic compaction and also represents the lost volume of aquifer storage.

Rates of water-level decline in some basins either have not changed or have increased slightly in recent years. These trends are indicated in Waterman Wash basin (fig. 26H), McMullen Valley (fig. 26I), Willcox basin (fig. 26J), and Douglas basin (fig. 26K). Annual pumpage rates remained essentially constant or increased slightly between the 1960's and 1970's in these basins. For the most part, these basins had less withdrawal, and the hydrographs may represent the period before the rates of inflow would be affected or the development effect has not reached the aquifer boundaries.

\section{STREAMFLOW DEPLETION}

The depletion of surface flow due to withdrawal of ground water has several effects. The reduction in stream base flow may be critical to the maintenance of riparian habitat and represents the removal of a source of streamflow infiltration recharge. Depletion of base flow and subsequent water-level decline can result in the reduction of aquifer transmissivity and well yield. The benefit of water-level declines along stream reaches is the reduction of evaporation and transpiration along the streams as a result of the loss of phreatophytes and an increase in the volume of permeable sediments potentially available to store surface runoff. Stream alluvium along the flood plain of most streams is the most effective recharge area of the basin aquifers.

\section{LAND SUBSIDENCE}

Because of the large volume of water that has been withdrawn from individual basins, large waterlevel declines have occurred. Water-level declines reflect the change from saturated to unsaturated conditions in the aquifer materials and are accompanied by increases in the intergranular loading within the sediments because of the removal of the buoyant effect of the water. The result is compaction of the aquifer material-principally the fine-grained sediments-by a reduction of the interstitial space. The degree of compaction is related to thickness and inelastic compressibility of the fine-grained sediments that constitute the aquifer. In basins where the aquifers consist of thick, compressible finegrained sediments, land subsidence can occur associated with large water-level declines. Because basins are surrounded by consolidated hard rocks, the vertical subsidence cannot occur uniformly over a large area, tension stresses are created near the perimeter of areas of large water-level decline and land subsidence (Laney and others, 1978). The result is the occurrence of earth fissures (vertical cracks). These vertical cracks are widened by erosion and create surface hazards.

Land subsidence has occurred in highly developed parts of central Arizona and is related to groundwater withdrawal and resultant water-level declines (Schumann and Poland, 1970). Near Eloy, total subsidence during 1952-77 was measured at $12.5 \mathrm{ft}$ at one bench mark (Laney and others, 1978). An area of more than $120 \mathrm{mi}^{2}$ is known to have subsided at least $7 \mathrm{ft}$ during 1952-77 (Laney and others, 1978), and more than $1,000 \mathrm{mi}^{2}$ is known to have subsided at least $3 \mathrm{ft}$ (Poland, 1981). Earth fissures were mapped at various times since they were noted in 1927 (Leonard, 1929). The fissures start as narrow linear features and increase in width and length as a result of additional ground movement and erosion. A fissure system in the Eloy area is more than $8 \mathrm{mi}$ long (fig. 27).

The effect of subsidence on basin hydrology is mainly the permanent loss of aquifer storage. The volume of lost storage within the aquifer is equal to the volume of land subsidence. A long period of time is usually required for inelastic compaction of finegrained sediments to be completed. A large amount 
of water is released from storage as a result of this inelastic compaction. However, this is only a onetime release and it is irreversible.

Physical effects of land subsidence and earth fissuring in certain basins are of major economic consideration. Changes in land-surface slope, especially along the outer area of subsidence, have resulted in damage to irrigation systems, sewer systems, pipe lines, streets, roads, interstate highways, and railroads. A common problem caused by compaction is the collapse of well casings. More extensive flooding from surface runoff may result from changes in the channel slope because of subsidence. Effects of subsidence and earth fissuring have necessitated rerouting the Central Arizona Project canal in a few places. Extensive investigations of subsidence need

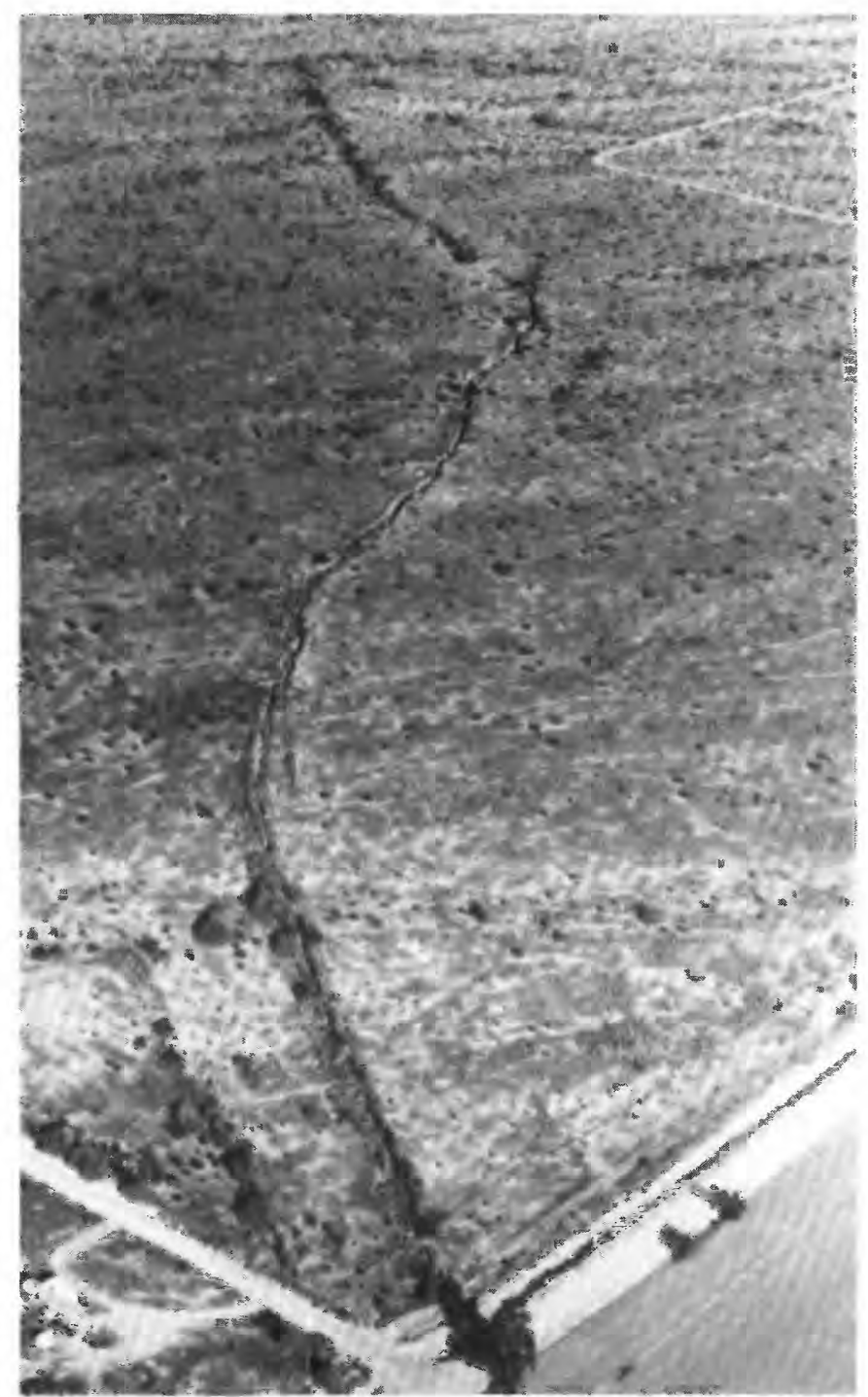

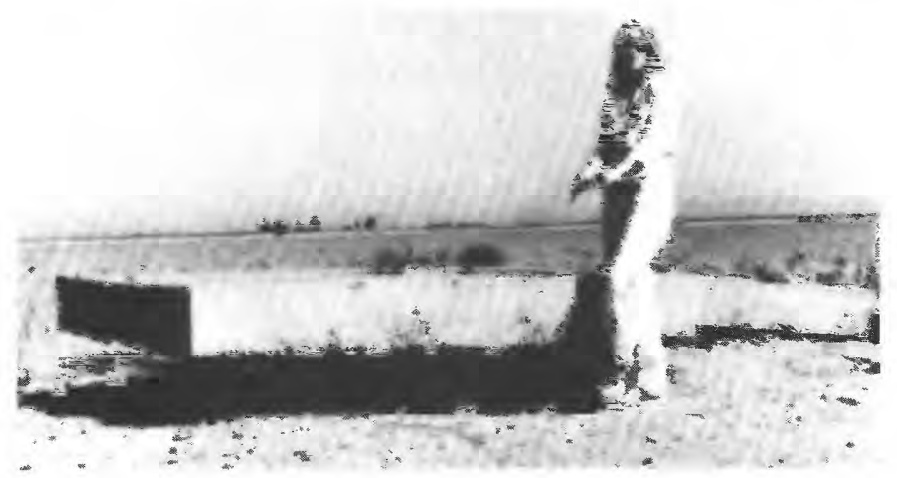
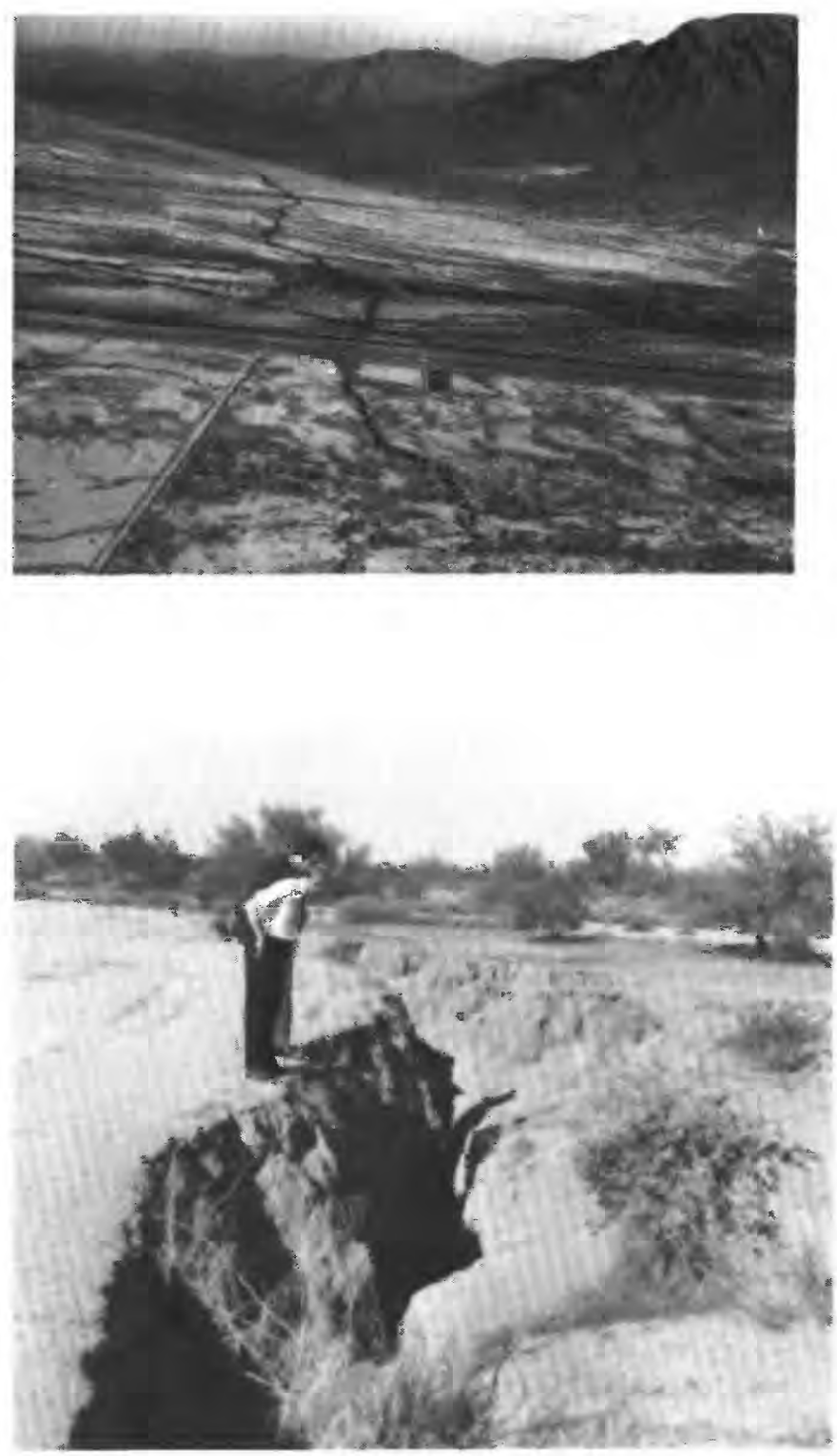

FIGURE 27.-Earth fissures and effects of land subsidence in alluvial basins near Eloy and Phoenix, Arizona. 
to be continued in order to develop methods of prediction of the occurrence and magnitude of subsidence and earth fissures associated with groundwater withdrawals and water-level declines.

\section{CHANGES IN HYDRAULIC CHARACTERISTICS WITH DEPTH}

The basins are filled with sedimentary material that ranges from less than $5,000 \mathrm{ft}$ to more than $10,000 \mathrm{ft}$ in depth. Depths to water range from zero to more than $1,300 \mathrm{ft}$ below the land surface. Most wells are 500 to $1,000 \mathrm{ft}$ deep, and a few wells are as much as 2,000 ft deep. Well logs represent the main source of data on the physical characteristics of the subsurface material; therefore, knowledge is limited by the maximum depth of wells. The reliability of the aquifer definition is dependent on the number,
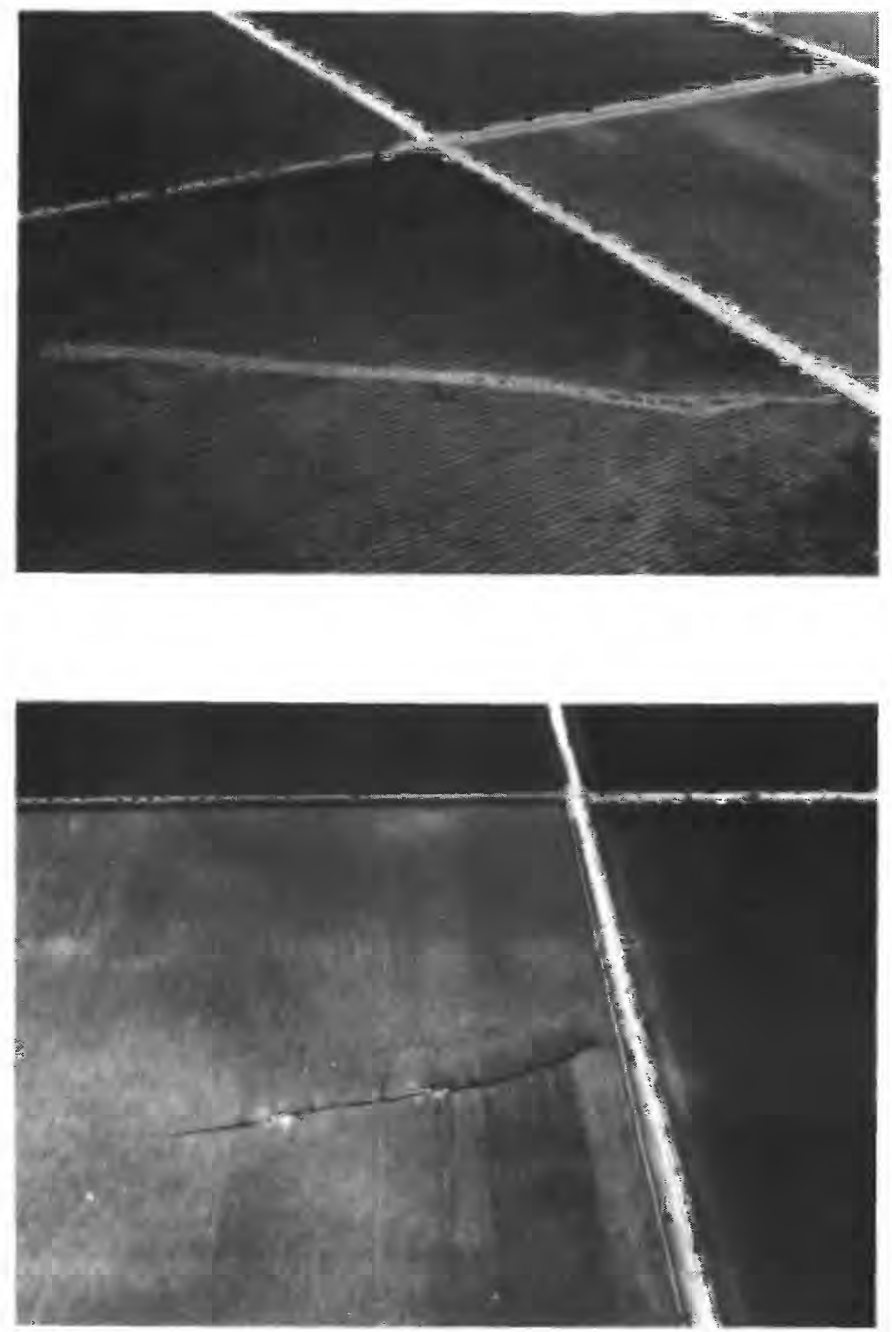

Figure 27.-Continued areal distribution, and descriptive detail of the well logs. In most basins, the characteristics of the sediments are not known below 2,000 ft. In general, data are available for only the upper 20 to 30 percent of the aquifer thickness. This upper part of the aquifers is thought to be the most hydrologically significant because most of the time-dependent water-level changes, recharge, discharge, lateral movement of ground water, and most of the inelastic compaction are occurring in that zone.

In the central basins, the deeper deposits are more fine grained, consolidated, and cemented than the shallow deposits. Extensive fine-grained sediments that contain massive evaporite deposits and gypsiferous mudstones occur at depths that exceed $1,000 \mathrm{ft}$. The ability of the deeper sediments to transmit and yield water is less than that of the near-surface sediments. Also, the presence of soluble salts degrades the water quality within the deeper sediments. In the Tucson basin, Laney (1972, p. 20) correlated the areas of decreasing dissolved-solids content with increasing depth where the aquifer was coarse grained. Where mudstone or gypsiferous mudstone was present at depth, the dissolved solids in the water increased with depth. Data are insufficient to extrapolate a relation to other basins.

\section{MANAGEMENT OF WATER RESOURCES}

Management of water resources by Federal, State, and local agencies was not a concern during the early stages of development of water resources in the alluvial basins in south-central Arizona. The early ground-water laws in Arizona established the right of the land owner to use the water that occurred under the land. Thus, ground water was the property of the individual land owner and not a public commodity. In the past decades, development and use of water was encouraged through the enactment of Federal and State programs and subsidies; as a result, overdevelopment of water resources in basins occurred. In an attempt to ameliorate the situation, another Federal program was initiated to import water to areas of overuse. The importation of water from the Colorado River by the Central Arizona Project will partially offset the overdevelopment of ground-water resources in central Arizona. More important in the movement toward reducing the longterm overdevelopment of ground water in basins was the enactment of the Arizona Groundwater Management Act of 1980 (Arizona Groundwater Management Study Commission, 1980). Agriculture was the driving force in the rapid development of the area 
and used 82 percent of the ground water pumped in 1980 (U.S. Geological Survey, 1982). As a result of the Arizona Groundwater Management Act of 1980, use of water for agriculture will be systematically reduced and financial constraints will be used to encourage efficiency in water use.

The Arizona Groundwater Management Act of 1980 has been called "a landmark in the history of United States water management" (Morrison, 1983) and is designed to restrict and control ground-water withdrawals. The act established four Active Management Areas (AMA) that encompass the areas having the greatest depletion in aquifer storage and two Irrigation Nonexpansion Areas (INA) that include areas having lesser development problems (fig. 28). In three of the AMA'sPhoenix, Prescott, and Tucson-the management goal is to reach a condition of safe yield by the year 2025. Safe yield is defined in the act as the achievement and maintenance of "a long-term balance between the annual amount of ground water withdrawn in the AMA and the annual amount of natural and artificial ground-water recharge in the AMA" (Arizona Groundwater Management Study Commission, 1980, p. III-10). The Pinal AMA (fig. 28 ) has the management goal of preserving the existing agricultural economy as long as possible, while being consistent with the long-term needs to preserve water supplies for future nonirrigation uses. The goal in the INA's is to restrict expansion of irrigated agriculture, which in turn will limit pumpage for irrigation uses.

Management plans take into consideration both supply and demand of water. Supply augmentation will occur through the importation of Colorado River water. Other possibilities that are being considered include cloud seeding to increase precipitation, vegetation modification and watershed management to increase runoff, in-stream and near-stream structures to increase recharge through stream infiltration, and reuse of effluent. Considerations to decrease demand include conservation, establishment of water rights, and water-use pricing.

Conservation is an integral part of the management plans for the AMA's. Water duties are being established on a per unit basis-per acre, per ton of ore, or per capita-and will gradually be reduced with time (Briggs, 1983). Within the AMA's, a system of water rights has been established, and the use of ground water is limited to those holding rights. New industrial and municipal uses of ground water are possible; however, new irrigation uses are prohibited (Briggs, 1983). The Arizona Groundwater Management Act of 1980 also allows a pump tax to be imposed on all ground-water withdrawals within the AMA's. The tax may ultimately be $\$ 5.00 /$ acrefoot, which would be a strong economic incentive to discontinue marginally profitable agriculture. The pump tax will be used to defray some of the administrative and management costs of the program and for purchasing and retiring agricultural lands. Throughout the history of development, water and the power used to pump the water were fairly cheap, which encouraged overuse as well as wasteful practices. The water-use pricing is needed for better conservation and, water being a valuable commodity in an arid environment, will eventually determine the effectiveness of the management plans.

Indian water-rights problems remain to be resolved. Lawsuits are pending that claim water rights for irrigable reservation lands far in excess of the available water supply. The considerations to be kept in the forefront are that the available water

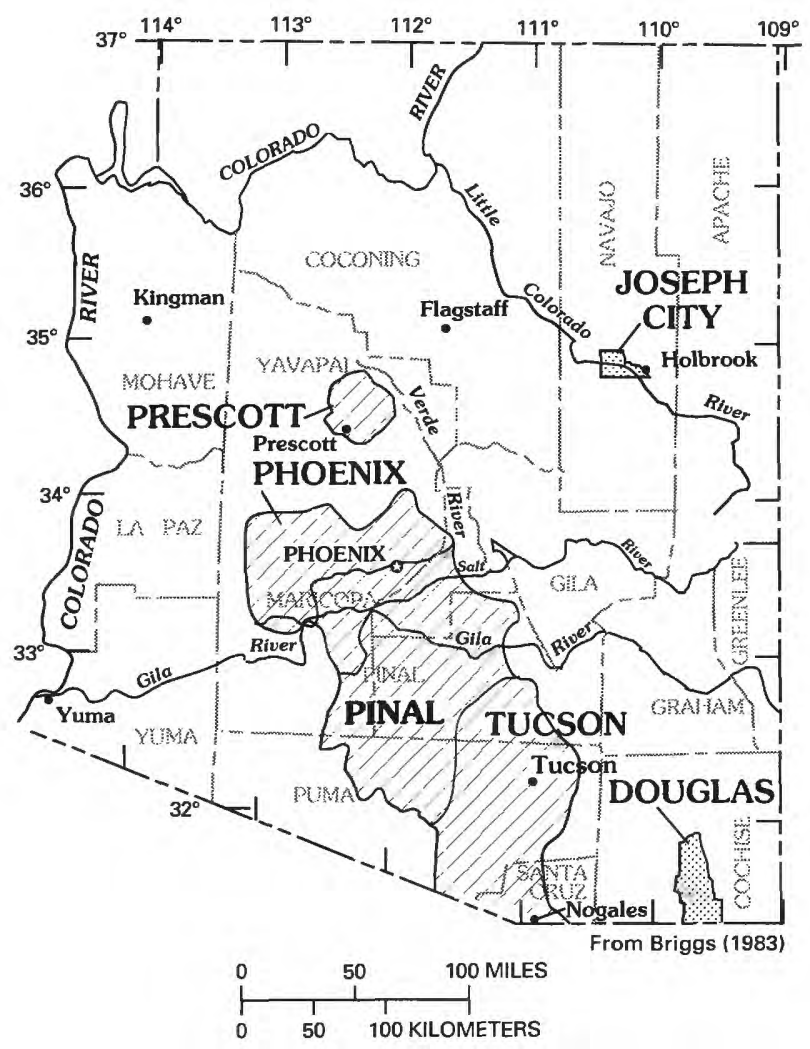

EXPLANATION

ACTIVE MANAGEMENT AREA IRRIGATION NONEXPANSION AREA

FiguRe 28.-Active Management Areas and Irrigation Nonexpansion Areas in Arizona. 
supply is a finite quantity and that basinwide management needs to prevail no matter the number or identity of the users.

The continual collection of geologic and hydrologic data is needed for successful management of the ground-water resources. Availability of improved technology and the need for cost-effective and efficient monitoring of ground-water systems make implementation of data-collection networks and programs essential. These additional data can be used to improve definition of the geohydrologic framework and the effects of development. Predictive capabilities, based on numerical simulations, are improving constantly and eventually will allow evaluation of development effects. The comprehension of how the ground-water systems function and the documentation of the hydrologic components are essential.

\section{SUMMARY}

The study of alluvial basins in Arizona and in parts of adjacent States is one of the regional aquifer-system studies conducted by the U.S. Geological Survey to systematically evaluate the Nation's major ground-water systems. The study described in this report includes about $82,000 \mathrm{mi}^{2}$ in south-central Arizona and parts of adjacent States. The study area consists of 72 basins that are considered to be individual hydrologic entities.

The primary purpose of this study was to describe and define the hydrogeologic system of the alluvial basins. The study efforts are to define the geologic boundaries of the basin aquifers, the ground-water resources available in the basins, and the degree of interconnection between adjacent basins and between streamflow and ground-water flow in the basins.

The study area is in the Basin and Range physiographic province and is characterized by broad valleys separated by sharply rising mountain ranges. The climate is arid to semiarid. Precipitation generally ranges from 3 to $30 \mathrm{in} . / \mathrm{yr}$, and potential evaporation ranges from 60 to 86 in./yr.

Alluvial basins in the study area were formed during the structural disturbance that formed the Basin and Range province, which probably occurred between about 15 to $4 \mathrm{~m}$.y. ago. Movement along high-angle normal faults near the present basin boundaries resulted in the formation of a series of generally north- to northwest-trending basins and mountain ranges.

The mountains consist of igneous, metamorphic, and consolidated sedimentary rocks that are exten- sively folded or faulted. The rocks of the mountains generally yield little water, especially in contrast to the alluvial sediments, and form the side and bottom boundaries of the basin aquifers.

The basins are filled with alluvial deposits that range from a few thousand feet to more than 10,000 $\mathrm{ft}$ in thickness. Basin subsidence was accompanied by deposition of locally derived sediments, which occurred at different rates throughout the area. As a result, the thickness, areal extent, and grain size of the alluvial deposits are highly variable. The sediments include a range of grain size from clay to gravel and may be unconsolidated to highly consolidated in a single basin. A general vertical sequence of sediments can be delineated throughout the study area. The sequence of sediments consists of preBasin and Range sediments overlain by basin-fill sediments and stream-alluvium deposits. Each unit of the sequence reflects discrete intervals of variable depositional conditions.

Pre-Basin and Range sediments were in place before the structural disturbance that created the present-day system of mountains and valleys. Clasts in the pre-Basin and Range sediments indicate source areas other than the mountains that presently surround the basins. Pre-Basin and Range sediments are faulted and tilted and are the deepest sedimentary unit in most basins.

During this study, the basin-fill sediments have been divided into lower and upper units. Lower basin fill was deposited when the basins had no external drainage. Generally, lower basin fill consists of extensive fine-grained material that locally includes gypsiferous mudstone, massive evaporites, and volcanics. Upper basin fill was deposited during the transition period of the basin-drainage systems from closed to integrated drainage and generally is more coarse grained than lower basin fill. Sediments in both units grade from coarse grained at the basin margin to fine grained at the depositional center of the basin. Lower basin fill may be locally faulted, and upper basin fill generally is not structurally disturbed.

Stream alluvium was deposited after filling of the basins and during the establishment of the present drainage system. Grain size ranges from boulders to clay but mainly consists of sand and gravel along the stream channels.

Ground water occurs within the pore spaces of the sediments that fill the basins. In general, the entire sequence of sediments in the basins is hydraulically connected and forms a single aquifer within a basin. Ground water generally occurs under unconfined conditions, although in places, confined conditions occur 
where extensive fine-grained facies of the basin fill are present. Depths to the water table range from at the land surface near streams to as much as $1,300 \mathrm{ft}$ below the land surface near mountain fronts.

Hydraulic conductivity of the aquifer sediments is related to the percentage of fine-grained material. In at least two basins where data are sufficient to estimate the spatial trends, areal patterns of finegrained material indicate a gradational change in aquifer properties from the basin boundary toward the basin center.

Before development, the ground-water budget of the study area was in equilibrium-inflow equaled outflow and no long-term change in storage occurred. Total inflow to the basins consisted of about 2.5 million acre-ft/yr of water as infiltration along major streams, mountain-front recharge, and underflow. Outflow consisted of evapotranspiration, streamflow, and underflow. These inflows and outflows were small in relation to the estimated 900 million acre-ft of water stored in the aquifers to a depth of $1,200 \mathrm{ft}$ below the land surface.

Development of water resources in the basins is principally for agriculture and was started in the 1860 's. Ground-water pumping began in the late 1800 's, and in 1942, ground-water pumpage totaled 1.7 million acre-ft. Rapid agricultural growth occurred during and after World War II, and by 1952, ground-water pumpage was 3.8 million acre-ft. During 1950-80, ground-water pumpage averaged more than 4.8 million acre- $\mathrm{ft} / \mathrm{yr}$. The volume of ground water withdrawn greatly exceeded the volume of recharge, thus a large amount of water was removed from aquifer storage, which resulted in large declines in water levels in some basins. Water-level declines that generally range from 50 to $450 \mathrm{ft}$ have occurred in major agricultural areas. These large water-level declines have resulted in inelastic compaction of fine-grained material of the basin fill accompanied by land subsidence and earth fissures. By 1980 , a total of 184 million acre-ft of ground water had been withdrawn. Slightly more than 50 percent of this volume was estimated to be removed from aquifer storage, and the remainder was balanced by decrease in natural ground-water discharge, increase in recharge, or a combination of both.

An assumption was made during the study that certain information was transferable among basins that shared geologic and hydrologic similarities. Hydrologic and geologic data were used to evaluate the potential of information transfer between basins. The trends and estimates of properties and processes were evaluated in basins where sufficient hydrogeologic data were available for interpretation. A conclusion was reached that the basin aquifers generally can be grouped into five categories on the basis of estimated unit downvalley flow and lithologic conditions. Within each group, the hydrogeology of the basin aquifers behave similarly. The categories are (1) southeast basins, (2) central basins, (3) west basins, (4) Colorado River basins, and (5) highland basins. The general geographic grouping of the basins of a category reflects the interrelation of hydrology and physiographic factors.

The southeast basins include stream infiltration and mountain-front recharge as major recharge sources, and evapotranspiration and discharge to streams as major discharge mechanisms. Ground water generally flows from the basin perimeter toward the central axis of the basin where most discharge occurs. Some ground water occurs under confined conditions within the lower basin fill.

In the central basins, a mix of all recharge and discharge mechanisms exist. Ground water flows from the basin perimeter and from the upgradient end toward the basin center, and then downvalley to the outflow point at the downstream end of the basin. Ground water generally occurs under unconfined conditions, but vertical head differences exist owing to clay lenses in the heterogeneous aquifer sediments.

The west basins include the most arid part of the study area, and very limited amounts of natural recharge and discharge occur. Ground water withdrawals are supplied principally by removal of water from aquifer storage. Ground water typically flows through the length of the basin with only very small amounts of mountain-front recharge. Ground water occurs under unconfined conditions; however, head differences between upper and lower parts of the aquifer may exist after development owing to the presence of fine-grained facies in the middle of the lithologic sequence.

The hydrogeology of the Colorado River basins is dominated by the flow of the Colorado River. Streamflow infiltration and evapotranspiration are the dominant recharge and discharge mechanisms, respectively. Ground water occurs under unconfined conditions in the upper parts of the aquifer, which includes stream alluvium and older alluvial deposits. Ground water occurs under confined conditions in the underlying fanglomerate, but this unit has not yet been developed as a source of water.

The alluvial aquifers of the highland basins have limited areal extent. Inflow to the basin aquifer occurs as underflow from the adjacent consolidatedrock aquifers and infiltration from streams. Discharge is principally evapotranspiration and base flow to streams. The basins are not connected and 
underflow from one basin aquifer to another basin aquifer does not occur. Ground water generally occurs under unconfined conditions.

Basins included in a particular category are characterized by similar geology and hydrology, and therefore the response of the basin aquifers to development probably would be similar. The problems associated with development-such as waterlevel declines, land subsidence and earth fissures, and streamflow depletion-are also common to basins of a specific category. The occurrence and magnitude of these problems generally can be estimated or evaluated for each group of the basins and for each basin within the group.

\section{SELECTED REFERENCES}

Anderson, S.R., 1988, Potential for aquifer compaction, land subsidence, and earth fissures in the Tucson basin, Pima County, Arizona: U.S. Geological Survey Hydrologic Investigations Atlas HA-713, 3 sheets.

Anderson, T.W., 1968, Electrical-analog analysis of groundwater depletion in central Arizona: U.S. Geological Survey Water-Supply Paper 1860, 21 p.

1972, Electrical-analog analysis of the hydrologic system, Tucson basin, southeastern Arizona: U.S. Geological Survey Water-Supply Paper 1939-C, 34 p.

-1983 , Implication of deep percolation to ground-water systems in south-central Arizona based on numerical-model studies, in Proceedings of the 1982 Deep Percolation Symposium: Arizona Department of Water Resources Report 4, p. $30-40$.

Andrews, D.A., 1937, Ground water in Avra-Altar Valley, Arizona: U.S. Geological Survey Water-Supply Paper 796-E, $22 \mathrm{p}$.

Arizona Groundwater Management Study Commission, 1980, Final report: Phoenix, Arizona Groundwater Management Study Commission report, $49 \mathrm{p}$.

Arizona Water Commission, 1975, Inventory of resources and uses: Arizona State Water Plan, Phase I, 224 p.

Armstrong, C.A., and Yost, C.B., Jr., 1958, Geology and groundwater resources of the Palomas Plain-Dendora Valley area, Maricopa and Yuma Counties, Arizona: Arizona State Land Department Water Resources Report 4, 49 p.

Babcock, H.M., and Kendall, K.K., 1948, Geology and groundwater resources of the Gila Bend basin, Maricopa County, Arizona, with a section on Quality of water, by J.D. Hem: U.S. Geological Survey open-file report, $26 \mathrm{p}$.

Ball, J.W., Nordstrom, D.K., and Jenne, E.A., 1980, Additional and revised thermochemical data and computer code for WATEQ2-A computerized chemical model for trace and major element speciation and mineral equilibria of natural waters: U.S. Geological Survey Water-Resources Investigations Report 78-116, $109 \mathrm{p}$.

Bennett, G.D., 1979, Regional ground water systems analysis: Water Spectrum, Fall 1979, p. 36-42.

Bentley, C.B., 1979a, Geohydrologic reconnaissance of the Lake Mead National Recreation Area-Hoover Dam to Mount Davis, Arizona: U.S. Geological Survey Open-File Report 79-690, $37 \mathrm{p}$. 1979b, Geohydrologic reconnaissance of the Lake Mead National Recreation Area-Mount Davis to Davis Dam, Arizona: U.S. Geological Survey Open-File Report 79-691, 34 p.

$1979 \mathrm{c}$, Geohydrologic reconnaissance of the Lake Mead National Recreation Area-Opal Mountain to Davis Dam, Nevada: U.S. Geological Survey Open-File Report 79-692, $36 \mathrm{p}$.

Blair, W.N., and Armstrong, A.K., 1979, Hualapai Limestone member of the Muddy Creek Formation-The youngest deposit predating the Grand Canyon, southeastern Nevada and northwestern Arizona: U.S. Geological Survey Professional Paper 1111, $14 \mathrm{p}$.

Briggs, P.C., 1969, Ground-water conditions in the Ranegras Plain, Yuma County, Arizona: Arizona State Land Department Water-Resources Report 41, 28 p.

1983, Ground-water management in Arizona: American Society of Civil Engineers, Journal of Water Resources Planning and Management, v. 109, no. 3, p. 195-202.

Brown, D.E., Carmony, N.B., and Turner, R.M., compilers, 1981, Drainage map of Arizona showing perennial streams and some important wetlands: Arizona Game and Fish Department map, scale 1:1,000,000.

Brown, S.G., 1976, Preliminary maps showing ground-water resources in the lower Colorado River region, Arizona, Nevada, New Mexico, and Utah: U.S. Geological Survey Hydrologic Investigations Atlas HA-542, 3 sheets.

Brown, S.G., Davidson, E.S., Kister, L.R., and Thomsen, B.W., 1966, Water resources of Fort Huachuca Military Reservation, southeastern Arizona: U.S. Geological Survey WaterSupply Paper 1819-D, 57 p.

Brown, S.G., and Schumann, H.H., 1969, Geohydrology and water utilization in the Willcox basin, Graham and Cochise Counties, Arizona: U.S. Geological Survey Water-Supply Paper 1859-F, 32 p.

Bryan, Kirk, 1925, The Papago country, Arizona-A geographic, geologic, and hydrologic reconnaissance, with a guide to Desert watering places: U.S. Geological Survey WaterSupply Paper 499, $436 \mathrm{p}$.

Coates, D.R., and Cushman, R.L., 1955, Geology and groundwater resources of the Douglas basin, Arizona, with a section on Chemical quality of the ground water, by J.L. Hatchett: U.S. Geological Survey Water-Supply Paper 1354, 56 p.

Cooley, M.E., 1977, Map of Arizona showing selected alluvial, structural, and geomorphic features: U.S. Geological Survey Open-File Report 77-343, 29 p.

Cooley, M.E., and Davidson, E.S., 1963, The Mogollon HighlandsTheir influence on Mesozoic and Cenozoic erosion and sedimentation: Arizona Geological Society Digest, v. 6, p. 7-35.

Dane, C.H., and Bachman, G.O., 1965, Geologic map of New Mexico: U.S. Geological Survey, scale 1:500,000, 1 sheet.

Davidson, E.S., 1973, Geohydrology and water resources of the Tucson basin, Arizona: U.S. Geological Survey WaterSupply Paper 1939-E, 81 p.

- 1979, Summary appraisals of the Nation's ground-water resources-lower Colorado region: U.S. Geological Survey Professional Paper 813-R, 23 p.

Davis, A.P., 1897, Irrigation near Phoenix, Arizona: U.S. Geological Survey Water-Supply Paper 2, 98 p.

Davis, G.H., Green, J.H., Olmsted, F.H., and Brown, D.W., 1959, Ground-water conditions and storage capacity in the San Joaquin Valley, California: U.S. Geological Survey Water-Supply Paper 1469, 287 p.

Drewes, Harald, 1980, Tectonic map of southeast Arizona: U.S. Geological Survey Miscellaneous Investigations Series Map I-1109, 2 sheets. 
-1981, Tectonics of southeastern Arizona: U.S. Geological Survey Professional Paper 1144, 96 p.

DuBois, S.M., and Smith, A.W., 1980, The 1887 earthquake in San Bernardino Valley, Sonora-Historic accounts and intensity patterns in Arizona: Arizona Bureau of Geology and Mineral Technology Special Paper No. 3, 112 p.

Eaton, G.P., Peterson, D.L., and Schumann, H.H., 1972, Geophysical, geohydrological, and geochemical reconnaissance of the Luke Salt body, central Arizona: U.S. Geological Survey Professional Paper 753, 28 p.

Eberly, L.D., and Stanley, T.B., 1978, Cenozoic stratigraphy and geologic history of southwestern Arizona: Geological Society of America Bulletin, v. 89, no. 6, p. 921-940.

Evans, L.G., and Haimson, J.S., 1982, Swab/RASA aquifer parameter study: Arizona Department of Water Resources, Final report for U.S. Geological Survey contract 14-08-0001$18268,21 \mathrm{p}$.

Fenneman, N.M., 1931, Physiography of western United States: New York, McGraw-Hill, 534 p.

Feth, J.H., and Hem, J.D., 1963, Reconnaissance of headwater springs in the Gila River drainage basin, Arizona: U.S. Geological Survey Water-Supply Paper 1619-H, 54 p.

Fields, R.L., 1986, Data-processing activities of the Southwest Alluvial Basins, RASA study, in Anderson, T.W., and Johnson, A.I., eds., Regional aquifer systems of the United States-Southwest Alluvial Basins of Arizona: American Water Resources Association Monograph Series No. 7, p. 17-23.

Fields, R.L., and Vetter, E.F., 1984, A data-management system for use in ground-water modeling and resource evaluation: U.S. Geological Survey Water-Resources Investigations Report 84-4014, $71 \mathrm{p}$.

Finnell, T.L., 1970, Pantano Formation, in Changes in stratigraphic nomenclature by the U.S. Geological Survey, 1968: U.S. Geological Survey Bulletin 1294-A, p. 35-36.

Freethey, G.W., 1982, Hydrologic analysis of the upper San Pedro basin from the Mexico-United States international boundary to Fairbank, Arizona: U.S. Geological Survey Open-File Report 82-752, 64 p.

Freethey, G.W., and Anderson, T.W., 1986, Predevelopment hydrologic conditions in the alluvial basins of Arizona and adjacent parts of California and New Mexico: U.S. Geological Survey Hydrologic Investigations Atlas HA-664, 3 sheets.

Freethey, G.W., Pool, D.R., Anderson, T.W., and Tucci, Patrick, 1986, Description and generalized distribution of aquifer materials in the alluvial basins of Arizona and adjacent parts of California and New Mexico: U.S. Geological Survey Hydrologic Investigations Atlas $\mathrm{HA}-663,4$ sheets.

Gillespie, J.B., and Bentley, C.B., 1971, Geohydrology of Hualapai and Sacramento Valleys, Mohave County, Arizona: U.S. Geological Survey Water-Supply Paper 1899-H, $37 \mathrm{p}$.

Gould, J.A., and Wilson, R.P., 1976, Map showing ground-water conditions in the Aravaipa Valley area, Graham and Pinal Counties, Arizona-1975: U.S. Geological Survey WaterResources Investigations 76-107, scale 1:125,000.

Gray, R.S., 1965, Late Cenozoic sediments in the San Pedro Valley near St. David, Arizona: University of Arizona, unpublished doctoral thesis, $198 \mathrm{p}$.

Halpenny, L.C., and others, 1952, Ground water in the Gila River basin and adjacent areas, Arizona-A summary: U.S. Geological Survey open-file report, $224 \mathrm{p}$.

Harbour, Jerry, 1966, Stratigraphy and sedimentology of the upper Safford basin sediments: University of Arizona, unpublished doctoral thesis, $242 \mathrm{p}$.
Hardt, W.F., and Cattany, R.E., 1965, Description and analysis of the geohydrologic system in western Pinal County, Arizona: U.S. Geological Survey open-file report, $92 \mathrm{p}$.

Hargan, B.A., 1978, Regional gravity data analysis of the Papago Indian Reservation, Pima County, Arizona: Tucson, University of Arizona, master's thesis, $104 \mathrm{p}$.

Harshbarger, J.W., Lewis, D.D., Skibitzke, H.E., Heckler, W.L., and Kister, L.R., 1966, Arizona water: U.S. Geological Survey Water-Supply Paper 1648, 85 p.

Hastings, J.R., and Turner, R.M., 1965, The changing mile-An ecological study of vegetation change with time in the lower mile of an arid and semiarid region: Tucson, University of Arizona Press, $317 \mathrm{p}$

Hayes, P.T., and Drewes, H.D., 1978, Mesozoic depositional history of southeastern Arizona, in Callender, J.F., Wilt, J.C., and Clemmons, R., eds., Land of Cochise: New Mexico Geological Society Guidebook, 29th Field Conference, p. 201208.

Heindl, L.A., 1967, Ground water in fractured volcanic rocks in southern Arizona, in Hydrology of fractured rocks: International Association of Scientific Hydrology Publication 74, v. 2, p. 503-513.

Heindl, L.A., and Armstrong, C.A., 1963, Geology and groundwater conditions in the Gila Bend Indian Reservation, Maricopa County, Arizona: U.S. Geological Survey WaterSupply Paper 1647-A, 48 p.

Heindl, L.A., Cosner, O.J., Page, H.G., Armstrong, C.A., and Kister, L.R., 1962, Summary of occurrence of ground water on the Papago Indian Reservation, Arizona: U.S. Geological Survey Hydrologic Investigations Atlas HA-55, scale 1:250,000.

Hollett, K.J., 1981, Maps showing ground-water conditions in the San Simon Wash area, Papago Indian Reservation, Arizona1979: U.S. Geological Survey Water-Resources Investigations Report 81-530, 2 sheets.

Hollett, K.J., and Garrett, J.M., 1984, Geohydrology of the Papago, San Xavier, and Gila Bend Indian Reservations, Arizona1978-81: U.S. Geological Survey Hydrologic Investigations Atlas HA-660, 3 sheets.

Hollett, K.J., and Marie, J.R., 1987, Simulation of the groundwater flow system and proposed withdrawals in the northern part of Vekol Valley, Arizona: U.S. Geological Survey WaterResources Investigations Report 86-4340, 68 p.

Hollyday, E.F., 1963, A geohydrologic analysis of mine dewatering and water development, Tombstone, Cochise County, Arizona: University of Arizona, master's thesis, $90 \mathrm{p}$.

Jennings, C.W., compiler, 1977, Geologic map of California: California Division of Mines and Geology, California Geologic Data Map Series, Map Number 2, 1:750,000, 1 sheet.

Kam, William, 1964, Geology and ground-water resources of McMullen Valley, Maricopa, Yavapai, and Yuma Counties, Arizona: U.S. Geological Survey Water-Supply Paper 1665, $64 \mathrm{p}$.

Kisser, K.G., and Haimson, J.S., 1981, Estimates of aquifer characteristics using driller's logs, in Proceedings of 1981 meeting of American Water Resources Association and Hydrology Section: Arizona-Nevada Academy of Sciences, May 1-2, 1981, v. 11, p. $112-116$.

Knechtel, M.M., 1938, Geology and ground-water resources of the valley of Gila River and San Simon Creek, Graham County, Arizona, with a section on The chemical character of the ground water, by E.W. Lohr: U.S. Geological Survey Water-Supply Paper 796-F, $41 \mathrm{p}$.

Laney, R.L., 1972, Chemical quality of the water in the Tucson basin, Arizona: U.S. Geological Survey Water-Supply Paper 1939-D, $46 \mathrm{p}$. 
1979a, Geohydrologic reconnaissance of the Lake Mead National Recreation area-Hoover Dam to Temple Bar, Arizona: U.S. Geological Survey Open-File Report 79-689, 42 p.

-1979b, Geohydrologic reconnaissance of the Lake Mead National Recreation area-Temple Bar to Grand Wash Cliffs, Arizona: U.S. Geological Survey Open-File Report 79-688, $72 \mathrm{p}$.

-1981, Geohydrologic reconnaissance of the Lake Mead National Recreation area-Las Vegas Wash to Opal Mountain, Nevada: U.S. Geological Survey Open-File Report 82-115, $23 \mathrm{p}$.

Laney, R.L., and Hahn, M.E., 1986, Hydrogeology of the eastern part of the Salt River Valley area, Maricopa and Pinal Counties, Arizona: U.S. Geological Survey Water-Resources Investigations Report $86-4147,4$ sheets.

Laney, R.L., Raymond, R.H., and Winikka, C.C., 1978, Maps showing water-level declines, land subsidence, and earth fissures in south-central Arizona: U.S. Geological Survey Water-Resources Investigations Report 78-83, 2 sheets.

Leake, S.A., and Clay, D.M., 1979, Maps showing ground-water conditions in the Gila River drainage from Texas Hill to Dome area and in the western Mexican drainage area, Maricopa, Pima, and Yuma Counties, Arizona-1977: U.S. Geological Survey Water-Resources Investigations Report 79-1540, 3 sheets.

Lee, W.T., 1904, The underground waters of Gila Valley, Arizona: U.S. Geological Survey Water-Supply Paper 104, $196 \mathrm{p}$.

1905, Underground waters of Salt River Valley, Arizona: U.S. Geological Survey Water-Supply Paper 136, 196 p.

Leonard, R.J., 1929, An earth fissure in southern Arizona: Journal of Geology, v. 37, no. 8, p. 765-774.

Littin, G.R., 1979, Maps showing ground-water conditions in the New River-Cave Creek area, Maricopa and Yavapai Counties, Arizona-1977: U.S. Geological Survey Open-File Report 79-1068, 2 sheets.

1981, Maps showing ground-water conditions in the Agua Fria area, Yavapai and Maricopa Counties, Arizona-1979: U.S. Geological Survey Water-Resources Investigations 81804,2 sheets.

Lohman, S.W., and others, 1972, Definitions of selected groundwater terms-revisions and conceptual refinements: U.S. Geological Survey Water-Supply Paper 1988, 21 p.

Lysonski, J.C., Sumner, J.S., Aiken, Carlos, and Schmidt, J.S., 1980 , The complete residual Bouguer gravity anomaly map of Arizona (IGSN 71): University of Arizona, Department of Geosciences Laboratory of Geophysics, 1 sheet.

Meinzer, O.E., and Ellis, A.J., 1916, Ground water in Paradise Valley, Arizona, in Contributions to the hydrology of the United States-1915: U.S. Geological Survey Water-Supply Paper 375-B, p. 51-75.

Meinzer, O.E., and Kelton, F.C., 1913, Geology and water resources of Sulphur Spring Valley, Arizona, with a section on Agriculture, by R.H. Forbes: U.S. Geological Survey WaterSupply Paper 320, 231 p.

Menges, C.M., and McFadden, L.D., 1981, Evidence for a latest Miocene to Pliocene transition from Basin-Range tectonic to post-tectonic landscape in southeastern Arizona: Arizona Geological Society Digest, v. 13, p. 151-160.

Metzger, D.G., 1951, Geology and ground-water resources of the northern part of the Ranegras Plain area, Yuma County, Arizona: U.S. Geological Survey open-file report, 31 p.

1957, Reconnaissance of the water resources of the Lonesome Valley area, Yavapai County, Arizona: U.S. Geological Survey open-file report, $4 \mathrm{p}$.
1968, The Bouse Formation (Pliocene) of the ParkerBlythe-Cibola area, Arizona and California, in Geological Survey Research 1968: U.S. Geological Survey Professional Paper 600-D, p. 126-136.

Metzger, D.G., Loeltz, O.J., and Irelan, Burdge, 1973, Geohydrology of the Parker-Blythe-Cibola area, Arizona and California: U.S. Geological Survey Professional Paper 486-G, $130 \mathbf{p}$.

Moosburner, Otto, 1972, Analysis of the ground-water system by electrical-analog model, Avra Valley, Pima and Pinal Counties, Arizona: U.S. Geological Survey Hydrologic Investigations Atlas HA-215, 2 sheets.

Morrison, Allen, 1983, Arizona's water strategy-Bring more in and restrict its use: American Society of Civil Engineering, Civil Engineering, v. 53, no. 4, p. 46-49.

Morrison, R.B., Menges, C.M., and Lepley, L.K., 1981, Neotectonic maps of Arizona: Arizona Geological Society Digest, v. 13 , p. $179-183$.

Nations, J.D., Hevly, R.H., Landye, J.J., and Blinn, D.W., 1981, Paleontology, paleoecology, and depositional history of the Miocene-Pliocene Verde Formation, Yavapai County, Arizona: Arizona Geological Society Digest, v. 13, p. 133-149.

O'Brien, K.M., and Stone, W.J., 1983, A two-dimensional hydrologic model of the Animas Valley, Hidalgo County, New Mexico: New Mexico Bureau of Mines and Mineral Resources Open-File Report 133, 60 p.

Olmsted, F.H., Loeltz, O.J., and Irelan, Burdge, 1971, Geohydrology of the Yuma area, Arizona and California: U.S. Geological Survey Professional Paper 486-H, 227 p.

Oppenheimer, J.M., and Sumner, J.S., 1981, Gravity modeling of the basins in the Basin and Range province, Arizona: Tucson, Arizona Geological Society Digest, v. 13, p. 111-115.

Pacific Southwest Interagency Committee, 1971, Lower Colorado Region Comprehensive framework study, Appendix V, Water Resources: Pacific Southwest Interagency Committee report, $115 \mathrm{p}$.

Parkhurst, D.L., Plummer, L.N., and Thorstenson, D.C., 1982, BALANCE-A computer program for calculating mass transfer for geochemical reactions in ground water: U.S. Geological Survey Water-Resources Investigations Report 82-14, 29 p.

Péwé, T.L., 1978, Terraces of the lower Salt River Valley in relation to the late Cenozoic history of the Phoenix basin, Arizona, in Guidebook to the geology of central Arizona: Arizona Bureau of Geology and Mineral Technology Special Paper No. 2, p. 1-45.

Peirce, H.W., 1974, Thick evaporites in the Basin and Range province, Arizona, in 4th Symposium on salt: Northern Ohio Geological Society, Cleveland, p. 47-55.

1981, Major Arizona salt deposits: Tucson, University of Arizona, Bureau of Geology and Mineral Technology Fieldnotes, v. 11 , no. 4 , p. $1-5$.

Poland, J.F., 1981, Subsidence in United States due to groundwater withdrawal: American Society of Civil Engineers, Journal of the Irrigation and Drainage Division, v. 107, no. IR2, June 1981, p. 115-135.

Poland, J.F., Lofgren, B.E., and Riley, F.S., 1972, Glossary of selected terms useful in studies of the mechanics of aquifer systems and land subsidence due to fluid withdrawal: U.S. Geological Survey Water-Supply Paper 2025, 9 p.

Pool, D.R., 1987, Geohydrology of McMullen Valley, west-central Arizona: U.S. Geological Survey Water-Resources Investigations Report 87-4140, $51 \mathrm{p}$.

Reynolds, S.J., 1980, Geologic framework of west-central Arizona, in Jenney, J.P., and Stone, Claudia, eds., Studies in 
western Arizona: Arizona Geological Society Digest, v. 12, p. 1-16.

Robertson, F.N., 1991, Geochemistry of ground water in alluvial basins of Arizona and adjacent basins of Nevada, New Mexico, and California: U.S. Geological Survey Professional Paper 1406-C, $90 \mathrm{p}$.

Robinson, T.W., 1958, Phreatophytes: U.S. Geological Survey Water-Supply Paper 1423, 84 p.

Robison, B.A., 1980, Description and analysis of Mesozoic "red beds," western Arizona and southeastern California, in Jenney, J.P., and Stone, Claudia, eds., Studies in western Arizona: Arizona Geological Society Digest, v. 12, p. 147154.

Roeske, R.H., 1978, Methods for estimating the magnitude and frequency of floods in Arizona: Arizona Department of Transportation Report ADOT-TS-15(121), $82 \mathrm{p}$.

Roeske, R.H., and Werrell, W.L., 1973, Hydrologic conditions in the San Pedro River Valley, Arizona, 1971: Arizona Water Commission Bulletin 4, 76 p.

Ross, C.P., 1923, The lower Gila region, Arizona, a geographic, geologic, and hydrologic reconnaissance, with a guide to Desert watering places: U.S. Geological Survey WaterSupply Paper 498, 237 p.

Ross, P.P., 1977, Map showing ground-water conditions in the lower Verde River area, Maricopa, Yavapai, and Gila Counties, Arizona-1976: U.S. Geological Survey Water-Resources Investigations Report 77-113, 1 sheet.

Sanger, H.W., and Appel, C.L., 1980, Maps showing groundwater conditions in the Hassayampa area, Maricopa and Yavapai Counties, Arizona-1978: U.S. Geological Survey Open-File Report 80-584, 2 sheets.

Scarborough, R.B., and Peirce, H.W., 1978, Late Cenozoic basins of Arizona, in Callender, J.F., Wilt, J.C., and Clemmons, R.E., eds., Land of Cochise: New Mexico Geological Society Guidebook, 29th Field Conference, p. 253-259.

Schreiber, J.F., Jr., 1978, Geology of the Willcox Playa, Cochise County, Arizona, in Callender, J.F., Wilt, J.C., and Clemmons, R.E., eds., Land of Cochise: New Mexico Geological Society Guidebook, 29th Field Conference, p. 277-282.

Schumann, H.H., and Poland, J.F., 1970, Land subsidence, earth fissures, and ground-water withdrawal in southcentral Arizona, U.S.A., in Land Subsidence: Tokyo, International Association of Scientific Hydrology Publication 88, v. 1., p. 295-302.

Schumann, H.H., and Thomsen, B.W., 1972, Hydrologic regimen of lower Tonto Creek basin, Gila County, Arizona-A reconnaissance study: Arizona Water Commission Bulletin 3, $39 \mathrm{p}$.

Schwalen, H.C., 1967, Little Chino Valley artesian area and ground-water basin: University of Arizona, Agricultural Experiment Station Technical Bulletin 178, $63 \mathrm{p}$.

Schwennesen, A.T., 1919, Ground water in San Simon Valley, Arizona and New Mexico, with a section on Agriculture, by R.H. Forbes: U.S. Geological Survey Water-Supply Paper 425-A, $35 \mathrm{p}$.

Shafiqullah, M., Damon, P.E., Lynch, D.J., Reynolds, S.J., Rehrig, W.A., and Raymond, R.H., 1980, K-Ar geochronology and geologic history of southwestern Arizona and adjacent areas: Arizona Geological Society Digest, v. 12, p. 201-260.

Smith, G.E.P., 1938, The physiography of Arizona valleys and the occurrence of groundwater: University of Arizona, Agricultural Experiment Station Technical Bulletin 77, 91 p.

1940, The groundwater supply of the Eloy district in Pinal County, Arizona: University of Arizona, Agricultural Experiment Station Technical Bulletin 87, 42 p.
Smith, L.P., 1981, Long-term streamflow histories of the Salt and Verde Rivers, Arizona, as reconstructed from tree rings: Tucson, University of Arizona, Laboratory of Tree-Ring Research, U.S. Army Corps of Engineers Contract DACW-09-80-C$0071,129 \mathrm{p}$.

Smith, L.P., and Stockton, C.W., 1981, Reconstructed stream flow for the Salt and Verde Rivers from tree-ring data: Water Resources Bulletin, v. 17, no. 6, p. 939-947.

Stewart, J.H., and Carlson, J.E., compilers, 1978, Geologic map of Nevada: U.S. Geological Survey, scale 1:500,000, 1 sheet.

Stiehr, P.L., 1981, Preliminary analysis of Arizona streamflowdata network for regional information: U.S. Geological OpenFile Report 81-920, 25 p.

Theis, C.V., Brown, R.H., and Meyer, R.R., 1963, Estimating the transmissibility of aquifers from the specific capacity of wells, in Bentall, Ray, compiler, Methods of determining permeability, transmissibility, and drawdown: U.S. Geological Survey Water-Supply Paper 1536-I, p. 331-341.

Thomsen, B.W., and Stulik, R.S., 1978, Hydrologic data for the Copper Basin area, a potential mining area in Yavapai County, Arizona: U.S. Geological Survey Open-File Report 78-413, 51 p.

Trauger, F.D., 1972, Water resources and general geology of Grant County, New Mexico: New Mexico State Bureau of Mines and Mineral Resources Hydrologic Report 2, 211 p.

Trescott, P.C., 1975, Documentation of finite-difference model for simulation of three-dimensional ground-water flow: U.S. Geological Survey Open-File Report 75-438, 32 p.

Trescott, P.C., and Larson, S.P., 1976, Documentation of finitedifference model for simulation of three-dimensional groundwater flow: U.S. Geological Survey Open-File Report 76-591, 21 p. (supplement to Open-File Report 75-438).

Tucci, Patrick, 1984, Surface resistivity studies for water-resources investigations near Tucson, Arizona, in Nielson, D.M., and Curl, Mary, eds., Surface and borehole geophysical methods in ground-water investigations: San Antonio, U.S. Environmental Protection Agency and National Water Well Association Conference Proceedings, February 6-9, 1984, p. 92-106.

Tucci, Patrick, Schmoker, J.W., and Robbins, S.L., 1982, Boreholegravity surveys in basin-fill deposits of central and southern Arizona: U.S. Geological Survey Open-File Report 82-473, 23 p.

1983, Density of basin-fill deposits calculated from borehole gravity data in four basins in central and southern Arizona: 53rd Annual International Society of Exploration Geophysicists meeting, September 11-15, 1983, Las Vegas, Nevada, expanded abstracts with biographies, p. 28-31.

Tucker, W.C., Jr., 1980, Tectonic geomorphology of the Luke Air Force Range, Arizona: Arizona Geological Society Digest, v. 12, p. $63-87$.

Turner, S.F., McDonald, H.R., and Cushman, R.L., 1945, Safe yield of the ground-water reservoirs in the drainage basins of the Gila and Salt River near Phoenix, Arizona: U.S. Geological Survey open-file report, $15 \mathrm{p}$.

Turner, S.F., and others, 1941, Water resources of Safford and Duncan-Virden Valleys, Arizona and New Mexico: U.S. Geological Survey open-file report, $58 \mathrm{p}$.

Twenter, F.R., and Metzger, D.G., 1963, Geology and ground water in Verde Valley-the Mogollon Rim region, Arizona: U.S. Geological Survey Bulletin 1177, 132 p.

U.S. Bureau of Reclamation, 1974, Western United States water plan, State of Arizona, Chino Valley unit appraisal report: U.S. Bureau of Reclamation report, $125 \mathrm{p}$.

- 1977a, Central Arizona Project-geology and groundwater resources report, Maricopa and Pinal Counties, Ari- 
zona: U.S. Bureau of Reclamation duplicated report, v. 1, $188 \mathrm{p}$.

1977b, Central Arizona Project-geology and groundwater resources report, Maricopa and Pinal Counties, Arizona: U.S. Bureau of Reclamation duplicated report, v. 2, $110 \mathrm{p}$.

U.S. Geological Survey, 1954, Compilation of records of surface waters of the United States through September 1950, Part 9. Colorado River basin: U.S. Geological Survey WaterSupply Paper 1313,749 p.

-issued annually, Water resources data for Arizona: U.S. Geological Survey Water-Data Report.

1969, Annual report on ground water in Arizona, spring 1967 to spring 1968: Arizona State Land Department Water-Resources Report 38, 54 p.

1982, Annual summary of ground-water conditions in Arizona, spring 1980 to spring 1981: U.S. Geological Survey Open-File Report 82-368, 2 sheets.

Wallace, B.L., and Laney, R.L., 1976, Maps showing groundwater conditions in the lower Big Chino Valley and Williamson Valley areas, Yavapai and Coconino Counties, Arizona-1975-76: U.S. Geological Survey Water-Resources Investigations 76-78, 2 sheets.

Weist, W.G., Jr., 1965, Geohydrology of the Dateland-Hyder area, Maricopa and Yuma Counties, Arizona: Arizona State Land Department Water-Resources Report 23, 46 p.

White, N.D., 1963, Analysis and evaluation of available hydrologic data for the San Simon basin, Cochise and Graham Counties, Arizona: U.S. Geological Survey Water-Supply Paper 1619-DD, 33 p.

1963, Ground-water conditions in the Rainbow Valley and Waterman Wash areas, Maricopa and Pinal Counties, Arizona: U.S. Geological Survey Water-Supply Paper 1669-F, $50 \mathrm{p}$.
White, N.D., and Hardt, W.F., 1965, Electrical-analog analysis of hydrologic data for San Simon basin, Cochise and Graham Counties, Arizona: U.S. Geological Survey WaterSupply Paper 1809-R, $30 \mathrm{p}$.

White, N.D., Leake, S.A., and Clay, D.M., 1979, Maps showing ground-water conditions in the northern part of the Gila River drainage from Painted Rock Dam to Texas Hill area, Maricopa, Pima, and Yuma Counties, Arizona-1978: U.S. Geological Survey Open-File Report 79-1537, 3 sheets.

White, N.D., Matlock, W.G., and Schwalen, H.C., 1966, An appraisal of the ground-water resources of Avra and Altar Valleys, Pima County, Arizona: Arizona State Land Department Water-Resources Report 25, $66 \mathrm{p}$.

White, N.D., and others, 1963, Ground-water conditions in the Rainbow Valley and Waterman Wash areas, Maricopa and Pinal Counties, Arizona: U.S. Geological Survey Water-Supply Paper $1669-\mathrm{F}, 50 \mathrm{p}$.

Wilson, D., 1962, A resume of the geology of Arizona: Arizona Bureau of Mines Bulletin 171, $140 \mathrm{p}$.

Wilson, E.D., and Moore, R.T., 1959, Structure of Basin and Range province in Arizona, in Heindl, L.A., ed., Southern Arizona Guidebook II: Tucson, Arizona Geological Society, p. 89-97.

Wilson, E.D., Moore, R.T., and Cooper, J.R., 1969, Geologic map of Arizona: Arizona Bureau of Mines map, scale 1:500,000.

Wilson, L.G., DeCook, K.J., and Neuman, S.P., 1980, Regional recharge research for southwest alluvial basins-Final report: University of Arizona, Water Resources Research Center, U.S. Geological Survey contract 14-08-0001-18257, $371 \mathrm{p}$.

Wilson, R.P., 1976, Maps showing ground-water conditions in the San Bernardino Valley area, Cochise County, Arizona1975: U.S. Geological Survey Water-Resources Investigations Report 76-81, 2 sheets. 